The Cronica de Anglia in London, British Library, Cotton MS Vitellius C.VIII, fols. 6v-21v: Another Product of John of Worcester's History Workshop

By Paul Antony Hayward

This article comprises a study and edition of the Cronica de Anglia, a significant but neglected history of England from AD 162 to 1125 whose historical value lies chiefly in its connections to other accounts of the period. Though it is uniquely preserved in a late twelfth-century manuscript from Rievaulx Abbey, close reading confirms that it was composed between 1125 and 1137, not in the north of England but in the West Midlands, almost certainly at Worcester Cathedral Priory. If it is not the work of the priory's foremost historian, John of Worcester (d. after 1143), then it was almost certainly produced under his direction. Not only are its contents closely related to his Chronica chronicarum and Chronicula, they also shed new light on John's interests and the ways in which he and his helpers compiled and edited their histories. Turning to another purpose materials used in John's other works, Cronica de Anglia arranges them in order to speak to questions about the relative antiquity and status of the kingdom's bishoprics, churches and monasteries-a concern not otherwise prominent in John's corpus. This chronicle also sheds precious light on the immediate reception of William of Malmesbury's histories of the English, especially the first edition of Gesta pontificum Anglorum. Carefully suppressing dangerous nuances in William's reportage, Cronica de Anglia betrays John's anxiety to avoid becoming entangled in Malmesbury's campaign against the king's chief minster, Bishop Roger of Salisbury (1102-39). The article concludes with the first complete edition of the text-an edition that provides a precise account of the Cronica's textual affinities.

In 1879 one of medieval history's founding fathers, Felix Liebermann, published a synopsis of a short history of the English, their church and their kings known after its rubrics as Chronica de Anglia. ${ }^{1}$ As Liebermann showed, this chronicle is largely a patchwork of known factoids, most of which are reported in greater detail in fuller histories such as John of Worcester's version of the Chronica

\footnotetext{
${ }^{1}$ Felix Liebermann (ed.), Ungedruckte anglo-normannische Geschichtsquellen (Strassburg, 1879), cited below as "ANG," 15-24. Cf. Thomas D. Hardy, Descriptive Catalogue of Materials Relating to Great Britain and Ireland to the End of the Reign of Henry VII, RS 26, 3 vols. in 4 pts. (1862-71), 2:88 (no. 124). In what follows Cronica de Anglia will be cited in the text by reference to the section numbers of the edition which, comprising the main component of the present article, appears at its conclusion. The following abbreviations will be employed: BHL = Bibliotheca Hagiographica Latina, Antiquae et Mediae Aetatis, Subsidia Hagiographica 6, 2 vols. (Brussels, 1898-99), with Henryk Fros (ed.), Novum Supplementum, Subsidia Hagiographica 70 (Brussels, 1986); OMT = Oxford Medieval Texts (Oxford, 1950-); RS = "Rerum Britannicarum Medii Ævi Scriptores, or Chronicles and Memorials of Great Britain and Ireland during the Middle Ages" (London, 1858-); S = Peter H. Sawyer, Anglo-Saxon Charters: An Annotated List and Bibliography, Royal Historical Society Guides and Handbooks 8 (London, 1968).
} 
chronicarum and William of Malmesbury's Gesta pontificum Anglorum. ${ }^{2}$ Students of Anglo-Saxon and Norman England - the contents range over the period from AD 162 to about 1125 - have tended therefore to set it aside as a derivative text, hardly worthy of close scrutiny. There are good reasons, however, why this chronicle should be printed in its entirety and exposed to further study. Liebermann's source-analysis is obsolete, and whilst the Cronica de Anglia may not provide much new data for the history of events, it represents a significant witness to England's historical culture at a critical period in its history. ${ }^{3}$ It sheds light on Worcester's contribution to the great wave of historical activity set in motion by the Norman Conquest: it provides insights into the methods involved in the construction of John's Cronica chronicarum and some of the earliest evidence for the reception of Malmesbury's histories. But before we can assess its historical value, it is necessary to put down a sound foundation - to establish a definitive text and to discover when, where, by whom, and how it was compiled; and the search for solutions to these problems has to begin with the manuscript.

\section{THE MANUSCRIPT}

The book which preserves the sole surviving copy of the Cronica de Anglia belonged to Rievaulx Abbey in the late twelfth century. Its contents are presently divided between two volumes in the British library, where one is part of the Royal Collection (MS 6.C.VIII) and the other part of the Cotton Collection (MS Vitellius C.VIII, fols. 4r-21v). In their slightly shrunken and trimmed state the leaves of the Cotton manuscript measure approximately $275 \times 195$ millimetres; those of the Royal

\footnotetext{
${ }^{2}$ John of Worcester, The Chronicle of John of Worcester, ed. and trs. R. R. Darlington, Patrick McGurk and Jennifer Bray, 3 vols., OMT (1995-), cited hereafter as "JWCC"; William of Malmesbury, Gesta pontificum Anglorum, ed. and trs. Rodney M. Thomson and Michael Winterbottom, OMT, 2 vols. (2007), cited hereafter as "WMGP." Since John's version of Chronica chronicarum has yet to be edited in full and because their variants have a bearing on what follows, it will sometimes be necessary to refer to the original manuscripts, in particular the autograph (Oxford, Corpus Christi College, MS 157), the interpolated text from Bury St Edmunds (Oxford, Bodleian Library, MS Bodley 297), that from Abingdon (London, Lambeth Palace Library, MS 42), and that from Peterborough (Cambridge, Corpus Christi College, MS 92, fols. $1 \mathrm{r}-167 \mathrm{v})$. They will be cited according to the usual sigla, that is, "C", "B", "L", and "P" respectively. In keeping with the usual practice, the annals are distinguished according to the Anno-Domini reckoning of Dionysius Exiguus rather than the alternative series of Marianus Scotus. The following abbreviations are used for the cognate texts: JWBishops = the episcopal tables as found in C, pp. 39-46; JWKings = the summary histories as found in C, pp. 47-54; JWChronicula= the breviate version of Chronica chronicarum found in Dublin, Trinity College, MS 503, fols. 37r-113v.

${ }^{3}$ For useful overviews of historical writing in the Anglo-Norman England, see esp. Elizabeth M. C. van Houts, "Historical Writing," in Christopher Harper-Bill and Elizabeth M. C. van Houts (eds), A Companion to the Anglo-Norman World (Woodbridge, 2002), 103-21; Robert Bartlett, England under the Norman and Angevin Kings, 1075-1225 (Oxford, 2000), 616-33; and Antonia Gransden, Historical Writing in England, 2 vols. (London, 1974-82), 1:105-218.
} 
manuscript $330 \times 210$. Divided into two columns of thirty-eight lines - identified as "a" and "b" in what follows - the text area in both manuscripts measures approximately $245 \times 145$ millimetres. The contents of the Royal manuscript may be listed as follows: ${ }^{4}$

1) Paulus Orosius, Historia aduersus paganos (fols. $1 \mathrm{r}-122 \mathrm{v}$ ), ${ }^{5}$ here titled De ormesta mundi, "The Measure of the World" (fol. 2r), and preceded by an argumentum (fol. 1r) which comprises a brief introduction to the work, borrowed in part from Gennadius. ${ }^{6}$ The final rubric appears at the foot of folio 122v: Explicit liber sancti pauli orosii presbyteri de ormesta mundi. The capitula for books two to seven appear at the head of each book on folios $14 \mathrm{v}$, 25v, 39rv, 57rv, 76r, and 95v. There are no capitula for book one, nor is there any space for them among the folios now extant.

2) Dares Phrygius, De excidio Troiae historia (fols. 123r-133v). Royal 6.C.VIII preserves a list of ten capitula numbered from xli. to .l. (fol. 123ra1-14), a prefatory letter in which Cornelius Nepos is cast as the translator of the work (fol. 123ra17-b7), and the first forty-six chapters of the "vulgate" version of the De excidio Troiae (fols. 123rb11-133v). The numeral .xlvii., from the beginning of the rubric to the next chapter, is the last word at the foot of folio $133 \mathrm{v}$.

A composite manuscript, Vitellius C.VIII was assembled for Sir Robert Cotton (1570/1-1631) in the early seventeenth century. Relatively lightly damaged in the Ashburnam House fire of 1731, the surviving leaves were mounted in cardboard frames and rebound in the mid nineteenth century, though not in the same order in which they had been arranged for Cotton. ${ }^{8}$ The damage to Vitellius

\footnotetext{
${ }^{4}$ For alternative descriptions, see Louis Faivre d'Arcier, Histoire et géographie d'un mythe: La circulation des manuscrits $d u$ De excidio Troiae de Darès le Phrygien (VIII $-X V^{e}$ siècles), Mémoires et documents de l'École des Chartes 82 (Paris, 2006), 52-53; George F. Warner and Julius P. Gilson, Catalogue of the Western Manuscripts in the Old Royal and Kings Collections, British Museum, 4 vols. (London, 1921), 1:145-6. Note also Birger Munk Olsen, L'Étude des auteurs classiques latins aux IXe et XIIe siècles, 4 vols. in 3 pts. (Paris, 1982-9), 1:371.

${ }^{5}$ Ed. and trs. Marie-Pierre Arnaud-Lindet, Histoires (Contre les Païens), 3 vols. (Paris, 1990-91). Cf. Janet M. Bately and David J. A. Ross, "A Checklist of Manuscripts of Orosius' Historiarum aduersum paganos libri septem," Scriptorium 15 (1961): 329-34, at 331.

${ }^{6}$ Gennadius, Liber de uiris inlustribus, § 40, ed. Ernest C. Richardson, TU 14 (Leipzig, 1896), 57-97, at 76; ArnaudLindet, Histoires (Contre les Païens), 1:251-2.

${ }^{7}$ De excidio Troiae historia, ed. Ferdinand Meister (Leipzig, 1873), 1-50. On this manuscript's place in the transmission of the text and its significance as an example of the frequency with which the text is associated with Orosius, see d'Arcier, Histoire et géographie d'un mythe, esp. 140, 154, 210-11, 213-4, 218-9, 234-46.

${ }^{8}$ There are two sequences of folio numbers. That on the cardboard frames, followed here, runs from 4 to 21 ; an older sequence on the leaves themselves proceeds 18, 19 and then from 2 to 17. For the story of how the damage was repaired, see Andrew Prescott, "“Their present miserable state of cremation': The Restoration of the Cotton Library," in C. J.
} 
C.VIII was largely confined to the upper fifth of the leaves, but at some point in its history, presumably when the folios were unbound, some ink was also eroded. Comprising a sub-unit that differs substantially in date and aspect from the other components of Vitellius C.VIII, the contents of folios $4 \mathrm{r}-21 \mathrm{v}$ may be listed as follows: ${ }^{9}$

3) Paulus Orosius, Historia aduersus paganos (fol. 4ra1). A single line comprising the final four words of the closing rubric: continens gesta annorum $. \tilde{V} . d c^{\text {torum }}$. et viii.

4) Peter Abelard, Versus ad Astralabium filium suum (fols. 4ra2-5r): a redaction of the poem comprising 226 of its 1042 verses, beginning Astralabi fili uita dulcedo paterne and ending abruptly Vilescit mulier suspicione cito. There is, as the poem's most recent editor notes, no apparent reason why the text in this witness ends where it does except that it "may have been used to fill up three pages". ${ }^{10}$ It ends at the bottom of the second column on folio $5 \mathrm{r}$; the next text begins at the top of the next page.

5) Dares Phrygius, De excidio Troiae historia (fol. 5v): a fragment comprising a list of chapter headings, numbered .i. to .xl., under the rubric Capitula libri sequentis.

6) Dares Phrygius, De excidio Troiae historia (fol. 6r-va26): another fragment comprising the final three chapters of the text, from Postquam dies illuxit Agamennon to Helenum et Andromachum mille ducenti, ${ }^{11}$ and an additional chapter, culled from the so-called "First Vatican Mythographer", that sets out the genealogy of Priam and Aeneas. ${ }^{12}$ It begins Dardanus ex Ioue et Electra, and ends Assaracus capem filium genuit, ex quo Anchises editus, Eneam filium procreauit. These chapters correspond to the last four items in the list of capitula on folio 123ra of Royal 6.C.VIII.

\footnotetext{
Wright (ed.), Sir Robert Cotton as Collector: Essays on an Early Stuart Courtier and his Legacy (London, 1997), 391454 (esp. 411, 428 and n. 167).

${ }^{9}$ Cf. Joseph Planta, A Catalogue of the Manuscripts in the Cottonian Library deposited in the British Museum (London, 1808), 424.

${ }^{10}$ Peter Abelard, Carmen ad Astralabium: A Critical Edition, ed. José M. A. Rubingh-Bosscher (Groningen, 1987), 65. There is a detailed account of the present manuscript at ibid., $47-50$, and of its relationship to the textual tradition at ibid., 61-65, 80-82.

${ }^{11}$ De excidio Troiae, ed. Meister, 50-52.

${ }^{12}$ Mythographus primus, § 132, ed. Peter Kulcsár, Mythographi Vaticani I et II, CCL 91C (1987), 3-91, at 55. On this addition to the De excidio, see d'Arcier, Histoire et géographie d'un mythe, 31 and 165.
} 
7) Cronica de Anglia (fols. 6va28-20v, 21r-vb6), described in its opening rubric as an account "of how the Britons, who first dwelt in Britain received Christ's faith and of how long they adhered to it, of the arrival and faith of the English, of the founding of bishoprics and the construction of abbeys, of the alteration of bishoprics and abbeys and their seats, [and] of certain kings and kingdoms of the English". At least one, possibly two folios, are missing between folios 20 and 21 . The last four fifths of the second column on folio $21 \mathrm{v}$ remain unfilled.

The correct order of the items is clearly $1,3,4,5,2,6$, and finally $7 .{ }^{13}$

All of the items, apart from 4, are identical in aspect, layout and decoration. The arabesque initials that signal the major and the lesser sections of text are invariably executed in a single colour (either red, green or blue/indigo), but many are ornamented with fine pen-work. ${ }^{14}$ Though the capitula may be the work of another or perhaps two hands, the body of items 1-3 and 5-7 appears to be the work of a single scribe. A different but near contemporary hand enters the verses from Abelard's poem on folios $4 \mathrm{r} 2-5 \mathrm{r}$. That is, the evidence suggests that the chief scribe left the three sides between the histories by Orosius and Dares Phrygius blank, that the book was first conceived as an historical miscellany, and that the poem was added later - as an afterthought. Still, the hands are all datable to the late twelfth century, and the scripts, artwork and general appearance of the manuscript are consistent with those of books produced in Cistercian houses in northern England at this time.

The provenance of the book is clear from the fourteenth-century ex-libris inscription in Royal 6.C.VIII (fol. 1r) and an entry in the Rievaulx library catalogue of about $1190 \times 1200$ which matches the exact contents of the book. The ex-libris inscription reads, Lib[er] s[anc]te Mar[ie] Ryevall[ensis], and the catalogue entry, Orosius de ormesta mundi, historia Daretis de bello Troiano, et versus Petri Abailardi ad filium, et cronica de Anglia in $i^{o}$ volumine. ${ }^{15}$ The book's re-composition

\footnotetext{
${ }^{13}$ That is, Royal 6.C.VIII, fols. 1-122, Vitellius C.VIII, fols. 4-5; Royal 6.C.VIII, fols. 123-133; Vitellius C.VIII, fols. $6-21$.

${ }^{14}$ E.g. Royal 6.C.VIII, fols. 2v, 15r, 26r, 29v, 40v, 41v, 59r, 73r, 73v, 78r, 81v, 96v, 120r, 123r; Vitellius C.VIII, fols. 6v. Images from the two MSS can be consulted at the British Library website, in the Online Galley (www.bl.uk/onlinegallery/) and in the Catalogue of Illuminated Manuscripts (www.bl.uk/catalogues/illuminatedmanuscripts/). Cf. Rodney M. Thomson, A Descriptive Catalogue of the Medieval Manuscripts in Worcester Cathedral Library (Cambridge, 2001), xvii, n. 1, who thinks that "the local style" of the initials suggests "a Worcester origin if not provenance" for the manuscript as well as the contents of the book.

${ }^{15}$ Cambridge, Jesus College, MS 34, fols. 1r-5r, ed. David N. Bell, The Libraries of the Cistercians, Gilbertines and Premonstratensians, Corpus of British Medieval Library Catalogues 3 (London, 1992), no. Z19.119 (§ 119). See also idem, An Index of Authors and Works in Cistercian Libraries in Great Britain, Cistercian Studies 130 (Kalamazoo, MI,
} 
as two parts seems to have taken place in the early seventeenth century. Certainly, it was a unified whole when it belonged to Henry Savile of Banke (1568-1617), ${ }^{16}$ but it had been dismembered by 1621, when the contents of Vitellius C.VIII were catalogued among Sir Robert Cotton's books in the list made in that year. ${ }^{17}$

\section{The Date of CRONICA DE ANGLIA}

The chronicle's mention of William of Warelwast as "now deprived of his sight, though not yet elderly" (§ 39) provides a strong terminus ad quem for its composition. Bishop of Exeter since his consecration in August 1107, Warelwast died at Plympton Priory on 26 September $1137 .{ }^{18}$ His successor was appointed at the Council of Northampton which met on 3 April $1138 .{ }^{19}$ September 1137 is a strong terminus, moreover, because the author, intervening to modify his source, has supplied the words nunc and non tamen senio, "now" and "not yet elderly". The account of the kings of Wessex and England that comprises the final section ends, similarly, with the death of William Rufus and the succession of Henry I ( $\$ 87$ ), implying — though this is a weaker indication because at this point the author is following John of Worcester rather slavishly — that the chronicle was composed before the coronation of King Stephen (22 December 1135). The latest event noted in the text is the consecration of Simon as bishop of Worcester, a ceremony which took place on 24 May $1125 .^{20}$ A terminus a quo of mid-to-late 1125 is also implied by the Cronica's dependence on Gesta pontificum, a work that was first put into wider circulation at about that time. As William of Malmesbury declares in his final chapter, Gesta pontificum was completed in 1125, the twenty-fifth year of Henry I's reign, and after the deaths of Pope Calixtus II and the Emperor Henry V. ${ }^{21}$ Calixtus

1992), 108; Neil R. Ker, Medieval Libraries of Great Britain: A List of Surviving Books, Royal Historical Society Guides and Handbooks 3 (2nd edn, London, 1964), 159 and n. 8.

${ }^{16}$ The contents of the entire book are listed, after the precise wording of the rubrics, as no. 2 in the catalogue of Savile's manuscripts (BL Add. MS 35213, fols. 5-32): see Julius P. Gilson, "The Library of Henry Savile of Banke," Transactions of the Bibliographical Society 9 (1906-8): 126-210, at 140-1; Andrew G. Watson, The Manuscripts of Henry Savile of Banke (London, 1989), 17. The owner's inscription, NETLTON HNRY SAVIL., appears in shorthand at the top of fol. 1r of Royal 6.C.VIII.

${ }^{17}$ BL Harley 6018, fols. 79-80 (no. 169). For the use and early circulation of the book while it was in Cotton's possession, see the data assembled by Colin G. C. Tite, The Early Records of Sir Robert Cotton's Library: Formation, Cataloguing, Use (London, 2003), 163.

18 Annales Plymptonienses, s.a. 1137, ed. $A N G, 26-30$, at 27.

19 JWCC, s.a. $1138(3: 240)$.

${ }^{20}$ The date is noted in JWCC, s.a. 1125.

${ }^{21} \mathrm{WMGP}, 5.278 .3-4$. See also the commentary, ibid., 2:325. 
died on 13 December 1124, Henry V on 23 May 1125. If the author of the Cronica had used a later edition of Gesta pontificum, it would have been possible to bring the terminus a quo forward to, say, around 1130; but several items imply dependence on the $\beta$-text. This much applies, for example, to the sentence about Warelwast ( $§ 39$ ), because the material on which it depends was removed from the later editions of Gesta pontificum. ${ }^{22}$ The outer limits for the production of Cronica de Anglia reside, therefore, at mid 1125 and September 1137.

\section{THe Place of COMPOSITION}

It has been asserted that Cronica de Anglia was produced in the same monastery as the surviving copy, making it "the most important original Cistercian chronicle" of the late twelfth century. ${ }^{23}$ There are, to be sure, aspects of Cronica de Anglia that point to composition at a monastery in northern England. Its reliance on a $\beta$-manuscript of Gesta pontificum can be construed as evidence to this effect, because five of the six surviving copies of this version have a northern provenance. Of the two primary witnesses to the $\beta$-text, one belonged to Belvoir, a Benedictine priory in Lincolnshire, while the other belonged to Byland, a Cistercian house in Yorkshire. ${ }^{24}$ The Cronica attempts, furthermore, to define the border between Deira and Bernicia, an issue that northern historians took up in the twelfth century. Like Reginald of Coldingham, a monk who wrote three hagiographical works between the early $1160 \mathrm{~s}$ and the $1180 \mathrm{~s},{ }^{25}$ the author places the boundary on the River Tyne $(\S 10)$. But these details scarcely amount to a convincing argument, for almost every other indication implies

\footnotetext{
${ }^{22}$ Further evidence for the author's reliance on the first edition can be found in $\S \S 39$ and 67.

${ }^{23}$ Elizabeth Freeman, Narratives of the New Order: Cistercian Historical Writing in England, 1150-1220, Medieval Church Studies 2 (Turnhout, 2002), 116 (emphasis added). Oddly, Freeman seems at one point to believe that Cronica de Anglia was composed while Henry I was alive (ibid., 117), but she fails to explain how Rievaulx could have produced so complex a work so soon after it was founded in March 1132. How, in the space of those three years, did it accummulate the requisite resources? Cf. also eadem, "Annals of Rievaulx," in Graeme Dunphy et al. (eds), Encyclopedia of the Medieval Chronicle, 2 vols. (Leiden, 2010), 1:82.

${ }^{24}$ BL Cotton MS Claudius A.V and Harley MS 3641. The former has been dated to the mid twelfth century, the latter to the end of the century: see WMGP, 1:xiii-iv.

${ }^{25}$ Reginald of Durham, Vita S. Oswaldi regis (BHL 6365), § 1, ed. Thomas Arnold, Symeonis monachi opera omnia, RS 75, 2 vols. (1882-5), 1:326-85, at 339. Cf. Richard of Hexham, De statu et episcopis Hagustaldensis ecclesiae, prol., ed. James Raine, The Priory of Hexham: Its Chroniclers, Endowments and Annals, 2 vols., Surtees Society Publications 64 and 66 (London, 1864-5), 1:1-62, at 2, who places the boundary on the River Tees. None of the pre-Conquest sources now extant defines the boundary between the two kingdoms, but it may be inferred from the evidence provided by Bede, Historia ecclesiastica gentis Anglorum, 4.2, ed. Bertram Colgrave and R. A. B. Mynors, OMT (1969), 332-4, cited hereafter as "Bede, $H E$," that Richard was right in so far as it probably lay on the River Tees: see Peter Hunter Blair, "The Boundary between Bernicia and Deira," Archaeologia Aeliana, 4th ser. 27 (1949): 46-59 (esp. 52-58); Thomas M. O. Charles-Edwards, Wales and the Britons, 350-1064 (Oxford, 2012), 383.
} 
that Cronica de Anglia was composed in the diocese of Worcester, if not at the Cathedral Priory itself. $^{26}$

The author's view of the primacy dispute suggests, to begin with, that he was based in the southern rather than the northern province of the English church, for he takes Canterbury's side throughout. He writes, for example, about how "the primate and patriarch of the English" was established in its first metropolis after Augustine of Canterbury restored the church of St Saviour in Canterbury ( $(3)$, and about how Lanfranc vindicated Canterbury’s position in the councils held in 1072 (§ 67). But by the 1120s, when the Chronica de Anglia was written, northern historians were giving open support to York's cause. Symeon of Durham, for example, supplied York with information about its bishops from Paulinus down to the late tenth century, information that they probably solicited for the purpose of strengthening their arguments; ${ }^{27}$ and in his Historia regum he rewrote John of Worcester's account of Thurstan's efforts to vindicate York's equality in ways that lent support to the latter's cause. Whereas John has Thurstan obstinately refusing to make a profession of obedience to Archbishop Ralph of Canterbury, ${ }^{28}$ Symeon sets out the basis of York's position: popes Gregory the Great and Honorius VI had provided that neither archbishop should make a profession to the other, except that he who had been blessed first ought to be considered the more senior while he lived; no bishop should seek to exercise lordship over another; and as Bede testifies no archbishop of Canterbury had "presumed" to claim the primacy of all England prior to Theodore's pontificate (67092). ${ }^{29}$ Whereas John attributes Pope Calixtus II's decision to consecrate Thurstan at the Council of Rheims to the latter's bribes and the failure of Archbishop Ralph's representatives to reach the pope in time ${ }^{30}$ Symeon suppresses all mention of bribery and deceit on Thurstan's part, and has Ralph's

\footnotetext{
${ }^{26}$ That it was compiled at Worcester in the middle of the twelfth century was previously suggested by McGurk in his edition of JWCC, 3:44, n. 2, and Paul Antony Hayward (ed.), The Winchcombe and Coventry Chronicles: Hitherto Unnoticed Witnesses to the Work of John of Worcester, Medieval and Renaissance Texts and Studies 373, 2 vols. (Tempe, AZ, 2010), 143, 246.

${ }^{27}$ Epistola de archiepiscopis Eboraci, ed. Arnold, Symeonis Opera Omnia, 1:222-8. Since the list of archbishops of York in the main witness (Cambridge, Corpus Christi College, MS 139, fols. 48v-49v), ends with Thurstan (§ 4), it must date from after 1114. The letter is addressed to a dean of York named "Hugh", implying composition before 1135 when he (or perhaps the second of two successive deans of that name) retired to Fountains Abbey: see Diana E. Greenway et al. (eds), John Le Neve: Fasti Ecclesiae Anglicanae 1066-1300 (London, 1968-), 6:7; Janet E. Burton (ed.), English Episcopal Acta, vol. 5, York, 1070-1154 (London, 1988), 120; Richard Sharpe, "Symeon as Pamphleteer," in David W. Rollason (ed.), Symeon of Durham, Historian of Durham and the North, Studies in North-Eastern History 1 (Stamford, 1998), 214-29, at 218-9.

${ }^{28}$ JWCC, s.a. 1117, following Eadmer of Canterbury, Historia novorum in Anglia, 5, ed. Martin Rule, RS 81 (1884), $237-8$.

${ }^{29}$ Symeon of Durham, Historia Regum, s.a. 1116, ed. Arnold, Symeonis Opera Omnia, 2:3-283, at 249-50, citing to Bede, $H E, 332$.

${ }^{30}$ JWCC, s.a. 1119, following Eadmer, Historia nouorum, 5 (pp. 255-8).
} 
representatives interjecting in a "presumptuous" attempt to prevent the ceremony going ahead; ${ }^{31}$ and so on. Chronica de Anglia's position on the primacy dispute is consistent, in short, with that of a southern historian.

Cronica de Anglia's topographical perspective suggests, secondly, that it was produced at Worcester. Its author certainly shows an interest in the city and its environs, praising it for its preeminence at the start of the eighth century when it became the seat of a bishopric, lamenting its destruction by fire, and providing several otherwise unattested etymologies for local place names:

Decorated then with high walls and fine ramparts, [Worcester] was more exalted and illustrious than many cities of the English $(\S 20)$.

Victia was named by a certain king of the Britons who was called "Wict". The name was taken from the shady wood which is called Wyre Forest. And he who was once called "bishop of the Hwicce", is now called "of Worcester", that is, "of Wyre-chester" $(\S 22)$.

In the year of the Lord 1113 the city of Worcester was incinerated by fire on Thursday 19 June with its principal church and all the others - and the castle (§ 71).

In the same province, also, is a monastery which is called "Tewkesbury". It was constructed by a certain Theodocus, from whom it received its name.... (§ 80).

To be sure, the explanation for the origins of the name Hwicce is rather problematic: there is no other record of a king of the Britons called Wict, ${ }^{32}$ and since the word means "chest" or "trunk", ${ }^{33}$ it seems likely that the name had its origins in a topographical feature - as a name inspired, perhaps, by the trough-like shape of the Severn Valley or the angular profile of the Malvern Hills. ${ }^{34}$ But the author's notion of how the bishop of Worcester's titles evolved is consistent with the records preserved in the cathedral's archive, ${ }^{35}$ and the names "Wyre Forest", Wirecestre and Wigornensis may well have had a

\footnotetext{
${ }^{31}$ Symeon, Historia regum, s.a. 1119 (p. 254).

${ }^{32}$ No such ruler is mentioned in Geoffrey of Monmouth, The History of the Kings of Britain: An Edition and Translation of De gestis Britonum, ed. Michael D. Reeve and trs. Neil Wright (Woodbridge, 2007), nor does he cover the foundation of Worcester (cf. $\S \S 116,156,196)$.

${ }^{33}$ Joseph Bosworth, An Anglo-Saxon Dictionary Based on the Manuscript Collections of the Late Joseph Bosworth, ed. Thomas N. Toller (Oxford, 1908-21), 581.

${ }^{34}$ For this suggestion, see Margaret Gelling, "The Place-Name Volumes for Worcestershire and Warwickshire: A New Look," in T. R. Slater and P. J. Jarvis (eds), Field and Forest: An Historical Geography of Warwickshire and Worcestershire (Norwich, 1982), 59-78, at 69; Della Hooke, The Anglo-Saxon Landscape: The Kingdom of Hwicce (Manchester, 1985), 10-11.

${ }^{35}$ Though Wigornensis episcopus had become the usual formula by the end of the ninth century, the bishops were sometimes self-consciously styled as Hwicciorum episcopus in a few charters dating from the tenth century: e.g. S 1290, where Bishop Cenwald (929-57) appears as praesul Huicciorum, and S 1352, where Bishop Oswald (961-92) appears as Hwicciorum archiepiscopus. For printed texts, see Codex diplomaticus aevi Saxonici, ed. John M. Kemble, 6 vols. (London, 1839-48), nos. 466 and 649. Cf. Bede, $H E, 5.23$ (p. 558), where the bishopric is identified the diocese as that prouinciae Huicciorum.
} 
common ancestry. ${ }^{36}$

An interest in local names nowhere emerges, more to the point, in Cronica de Anglia's coverage of the north, and there are many topographical errors in its treatment of places at some distance from Worcester. Much Wenlock, for example, is placed in Herefordshire rather than Shropshire ( $(81)$. St Albans is placed in Bedfordshire $(\S \S 32,79)$, an error that the author has carried over from his source - a marginal addition in the autograph copy of the Chronica chronicarum or perhaps its source, Gesta pontificum. ${ }^{37}$ He thinks, likewise, that Trumwine had his seat at Candida Casa, and that Candida Casa lay "in the land of the Picts" (§ 34), mistakes which he shares with the episcopal tables in the prelims to John of Worcester's version of the Chronica chronicarum. ${ }^{38}$

If, thirdly, Cronica de Anglia had been produced at a northern monastery one would expect the six sections at the conclusion of the work which survey England's kingdoms and their rulers $(\S \S$ 82-87) to betray the influence of the history known as the Libellus de primo Saxonum uel Normannorum aduentu siue de eorundem regibus. Probably produced at Durham between 1123 and 1133 and influential in the north, ${ }^{39}$ this survey of the major pre-Conquest kingdoms and their rulers

\footnotetext{
${ }^{36}$ It is thought that the name might derive from that for a local river called Vigora, a Gallo-Celtic name that may have meant "winding river": Allen Mawer and Frank M. Stenton, The Place-Names of Worcestershire, English Place Name Society 4 (Cambridge, 1927), 19-20; Hooke, Anglo-Saxon Landscape, 34.

${ }^{37}$ The error originated in WMGP 4.179 .1 , but the pattern of verbal parallels implies that both sections were more closely related to JWCC $\left(\mathrm{C}^{3} \mathrm{~B}\right)$, s.a. 1048. In the margins of C, John's autograph manuscript, the relevant item presently reads Hertfordensi instead of Bedefordensi, but Hertfor- is there written over an erasure. The copy made a Bury St Edmunds, MS B, has Herfordensis.

${ }^{38}$ Trumwine is identified as the first bishop of Candida Casa - a see located in the land of the Picts - in JW's table of northern bishops (C, p. 45). Bede, HE, 4.12, 26 (pp. 370, 428), clearly implies that Trumwine's see was based at Abercorn, and close to the Firth of Forth, but in ibid., 3.4, he had also treated Ninian (whose see was located at Candida Casa) as a missionary active among the "southern Picts".

${ }^{39}$ Since it was available when the Cronica was produced, the version that matters most for present purposes is that found in (1) Liège, Bibliothèque de 1'Université, MS 369C, fols. 88r-94r (s.xii ${ }^{2 / 4}$, Durham?), and (2) BL Cotton MS Domitian A.VIII, fols. 2 r-11r (s.xiii ${ }^{1}$, England). In these copies the original hands enumerate the bishops of Durham as far as Ranulf Flambard (1099-1128) and the archbishops of Canterbury as far William of Corbeil (1123-36). Their successors were consecrated in 1133 and 1139 (Greenway, Fasti (n. 27 above), 2:4, 30). The episcopal lists were extended a little further in the making of two slightly later copies: (3) Oxford, Magdalen College, MS 53, pp. 145-168 (s.1135×39, Tynemouth or St Albans?); and (4) BL Cotton MS Caligula A.VIII, fols. 28r-36r (s.xii ${ }^{3 / 4}$, Durham). An expanded version, much indebted to the prelims to the Chronica chronicarum (and perhaps also to Cronica de Anglia) and dating from between 1164 and 1173, are preserved in (5) Durham, Cathedral Library, MS B.II.35, fols. 131r-141v (s.1164×73, Durham); and (6) Cambridge, Corpus Christi College, MS 66, pp. 66-98 (s.xii ${ }^{4 / 4}$, Durham? / s.xii ${ }^{\text {ex }}$, Sawley). The version found in (1) is partially printed in Arnold, Symeonis Opera Omnia, 2:365-84; that found in (4) in John Hodgson Hinde, Symeonis Dunelmensis opera et collectanea, Surtees Society Publications 51 (Durham, 1868), 202-15. The best account of the dating and provenance of these manuscripts remains Bernard Meehan, "A Reconsideration of the Historical Works Associated with Symeon of Durham: Manuscripts, Texts and Influences" (unpubl. PhD dissertation, University of Edinburgh, 1979), pp. 66-75 and 125-66; idem, "Durham Twelfth-Century Manuscripts in Cistercian Houses", in David W. Rollason, Margaret Harvey and Michael Prestwich (eds), Anglo-Norman Durham, 1093-1193 (Woodbridge, 1994), 439-49 (esp. 446). But for the dating and construction of (1), see Caroline D. Eckhardt, "Geoffrey of Monmouth's Prophetia Merlini and the Construction of Liège University MS 369C," Manuscripta 32 (1988): 176-84. On the later versions of De aduentu, see also Christopher Norton, "History, Wisdom and Illumination," in Rollason, Symeon of
} 
treats many of the same topics as these sections. Both begin, for example, with Woden and his descendants and the kingdoms that they founded. The Cronica de Anglia turns first to the kings of Kent, then to those of the East Angles, the East Saxons, the Mercians, and finally the West Saxons and the English as a whole. As presently preserved, there is no section for the kings of Northumbria, but they were probably covered in the lacuna between folios 20 and 21. De primo Saxonum uel Normannorum aduentu covers the same ground, but in a somewhat different order and with divergent levels of detail: the section on Woden's genealogy is much fuller; those on the kings of Kent, of the East Saxons and of the Mercians are much briefer; its most expansive sections are those that cover the West-Saxons and the Northumbrians. Given their shared reliance on the corpus of Anglo-Saxon regnal and episcopal lists ${ }^{40}$ and the narrow compass of the subject matter, similarities are inevitable, but the wording and detail differ greatly. Cronica de Anglia provides, for example, coverage of Woden's ancestors going back to Noah, and names all seven of his sons $(\S 82)$; in its earliest version De primo Saxonum aduentu confines its treatment to the five lines of descent that gave rise to the royal houses of Deira, Bernicia, Kent, Mercia and Wessex. ${ }^{41}$ Both histories note, to provide another example, the pan-Britannic authority that Æthelstan achieved, but with differing emphases. Whereas the earliest version of De primo Saxonum aduentu says that Æthelstan "was the first of the kings from the English to hold the monarchy of all Britain, for he subjugated to himself Scotland and Cumbria and the other provinces of the Isles", 42 Cronica de Anglia says that he was "crowned king of the English and pronounced emperor of all Britain by everyone" ( $§ 87)$. Everything suggests, in short, that De primo Saxonum aduentu and Cronica de Anglia originated in isolation from each other.

Cronica de Anglia's treatment of this material is nearly identical, moreover, to that of the summary histories found among the prelims to Chronica chronicarum, ${ }^{43}$ and especially — though only for the four sections that cover Kent, the East Angles, the East Saxons, and the Mercians those that John inserted into his Chronicula, where they interrupt that history's coverage of the tenth

Durham, 61-105 (esp. 76-77, 82-86). On the influence of De primo Saxonum adventu, see Anne Lawrence-Mathers, "William of Newburgh and the Northumbrian Construction of English History," Journal of Medieval History 33 (2007): 339-57 (esp. 347-50); H. S. Offler, Medieval Historians of Durham (Durham, 1958), esp. 11-12.

${ }^{40}$ On the corpus of pre-Conquest lists of kings and bishops and its evolution, see David N. Dumville, "Kingship, Genealogies and Regnal Lists," in Peter H. Sawyer and Ian N. Wood (eds), Early Medieval Kingship (Leeds, 1977), 72104; R. I. Page, "Anglo-Saxon Episcopal Lists, Parts I and II", Nottingham Medieval Studies 9 (1965): 71-95; idem, “Anglo-Saxon Episcopal Lists, Part III," ibid., 10 (1966), 2-24; Simon D. Keynes, "Episcopal Lists," in Michael Lapidge, John Blair, Simon Keynes, and Donald Scragg (eds), The Wiley Blackwell Encyclopaedia of Anglo-Saxon England (2nd edn, Oxford, 2014), 177-8.

${ }^{41}$ Arnold, Symeonis Opera Omnia, 2:366; Rollason, Symeon of Durham, pl. 23.

${ }^{42}$ Arnold, Symeonis Opera Omnia, 2:372.

${ }^{43}$ Printed by Benjamin Thorpe from MSS C, B, L, and P in Florentii Chronicon ex Chronicis, 1:258-76. 
century. ${ }^{44}$ To explain, the Chronicula is an alternative, breviate, version of the Worcester Chronica chronicarum which is uniquely preserved in Dublin, Trinity College, 503 (a manuscript usually known as "G"), folios 37r-113v, where the text was copied by the scribe who is thought to be John himself. Chronicula was, furthermore, John's own name for this history: he says that "in this little chronicle of ours" he is abbreviating materials that may be found in a fuller form in his "chronicle of chronicles", and that he has taken care to include "in this little book only the more useful things". 45 An especially striking textual parallel is Cronica de Anglia's inclusion of nine lines of verse that also appear, albeit with a few variations, in Chronicula's version of the "summary histories". Both texts describe Æthelberht of Kent (d. 516), for example, as Primus et Anglorum petit alta polorum, "the first and highest of the pole-stars of the English" ( $\S 83) .{ }^{46}$ The regnal histories that John included in the prelims to Chronica chronicarum lack these verses. Concerned with founder figures, saints and other heroes of the church, they resemble the metrical entries found in some liturgical calendars. ${ }^{47}$ Several take the form of leonine hexameters with bisyllabic rhyme, a type of verse seldom practiced in England before the early twelfth century, ${ }^{48}$ but one that flourished in the West Midlands at this time. ${ }^{49}$

The range of the Cronica de Anglia's links with John's corpus all but proves, fourthly, that it was compiled at Worcester. John's version of Marianus Scotus's Chronica chronicarum was a complex web of diverse materials, yet numerous verbal parallels indicate that Cronica de Anglia is related to many different parts of this work — not just to the chronicle of the Sixth Age that takes up most of book three, but also to the auxiliary texts that comprise the preliminary matter. Parallels that

\footnotetext{
${ }^{44} \mathrm{JWChronicula}$ (fols. $64 \mathrm{v}-69 \mathrm{v}$ ). It should be noted that this manuscript preserves two alternative sets of the summary histories. There is the partial set just mentioned which occurs among the folios copied by John himself (fols. 37r-113v), and there is the complete set which is found among those folios (fols. $1 \mathrm{v}-36 \mathrm{v}$ and $113 \mathrm{v}-151 \mathrm{v}$ ) that were added to the book in the mid twelfth century, after it had reached Gloucester. The latter set is almost identical to that found in the autograph of JWCC (C, pp. 47-54).

45 JWChronicula (fols. 64v, 71v and 76r): “...succincte perstringimus in hac chronicula nostra...”; "Horum omnium acta pessima, qui nosse uoluerit, seriatim pleniusque reperiet scripta in cronicarum chronica. Huic uero libello dumtaxat utiliora studuimus inserere"; "Hęc seriatim omnia scire uolentibus, patefaciet chronicarum chronica. Huic uero libello hec minime inseruimus breuitatis causa". See Hayward, Winchcombe and Coventry (n. 26 above), 74.

${ }^{46}$ Cf. JWChronicula (fol. 65v).

${ }^{47}$ Cf. Patrick McGurk, "The Metrical Calendar of Hampson: A New edition,” Analecta Bollandiana 104 (1986): 79125; Michael Lapidge, "A Tenth-Century Metrical Calendar from Ramsey," Revue Bénédictine 104 (1984): 326-69; rpt in idem, Anglo-Latin Literature, 900-1066 (London, 1993), 343-86; André Wilmart, "Un témoin anglo-saxon du calendrier métrique d'York," Revue Bénédictine 46 (1934): 41-69.

${ }^{48}$ Lapidge, "A Metrical Calendar from Ramsey," 377.

49 There are, for example, many examples among verses that appear in the calendar of the Winchcombe Computus (BL Cotton MS Tiberius E.IV, fols. 35r-40v), ed. Lapidge, "A Metrical Calendar from Ramsey,” 383-6. There is, it should be noted, every likelihood that Worcester supplied the main exemplar for this calendar: see Hayward, Winchcombe and Coventry (n. 26 above), 100, 103, 169-73.
} 
suggest a relationship with the main body of Chronica chronicarum occur in at least fifty-two of the eighty-seven sections; ${ }^{50}$ verbal matches of the royal genealogies and summary histories of the heptarchic kingdoms occur in six sections $;{ }^{51}$ and data drawn from the tables of bishops figures in at least eleven sections. ${ }^{52}$ Some fourteen sections, moreover, have passages, including lengthy tranches of text, that are closer to the Chronicula than to the analogous parts of John's Chronica chronicarum. ${ }^{53}$ It is difficult to determine the nature and direction of the relations that produced these verbal parallels — it is possible, indeed, that some sections of Cronica de Anglia were the "immediate source" of corresponding passages in Chronica chronicarum and/or the Chronicula. But whatever the answers to that question (and a tentative suggestion will be ventured in the next section of this introduction), the general pattern suggests that the author of the Chronica de Anglia had a profound knowledge of John's works - that he had some involvement in the production of these other texts. At one point, furthermore, the author does not just "mirror" a passage in Chronica chronicarum, he seems to show an awareness of how this item was generated even though the latter text nowhere identifies the source. ${ }^{54}$

Cronica de Anglia exhibits, fifthly, many of the stylistic emphases that characterise John's works such as his concern to preserve the words of his sources and his interest in working out and recording the durations of regimes and dominions over the longer term. The latter tendency figures frequently in this text, as in the following five examples: ${ }^{55}$

After [Eatta] the bishops of Lindsey had the seat of their episcopate at Dorchester for 354 years, until Remigius, a Norman by birth, the seventeenth bishop of Lindsey, by the license of King William the Elder, moved the bishopric from Dorchester to Lincoln (§ 31).

After Bishop Acca of Hexham, about whom Bede makes mention among other saints at the end of the History of the English, yet there were seven Hexham bishops one after another for eighty-eight years altogether $(\S 33)$.

From the year of the Lord 707, in which the holy Aldhelm first received the episcopate of Sherborne, until the year 1069, in which, as we said, Bishop Hermann of Ramsbury moved the episcopal see to Salisbury, are reckoned 362 years and twenty-four prelates presiding over the see

\footnotetext{
${ }^{50}$ Cronica de Anglia, $\S \S 1-4,6-7,11-22,25-35,38-39,41-56,58-60,63-65,68-81$. For the cross-references to JWCC, see the apparatus to the edition that follows below.

${ }^{51}$ Cronica de Anglia, $\S \S 82-87$.

${ }^{52}$ Cronica de Anglia, §§ 7, 8, 9, 19, 28, 31, 36, 37, 39, 46, 47.

${ }^{53}$ Chronica de Anglia, $\S \S 20,36,56,57,59,61,63,64,65,68,69,83,85,86$.

54 The rubric to this section implies that the author knew that the survey of Britain near the conclusion of Bede, $H E$, 5.23, was its ultimate source, but the matching passage in JWCC, s.a. 731, nowhere makes that explicit. I say "seems to show" because although the rubrics were probably supplied by the author, there remains a possibility that they were provided by a scribe. But for another instance, consider Cronica de Anglia, § 20.

${ }^{55}$ For the other examples, see Cronica de Anglia, $\S \S 1,2,3,7,15,25,31,32,39,46,47,83,86$.
} 
one after another $(\S 37)$.

From the year of the Lord 908, in which Æthelhelm was made the first bishop of Wells, until the year of the Lord 1091, are numbered 182 years, in which fourteen prelates presided over the see one after another $(\S 38)$.

[Ely] had abbots one after another until the ninth year of the reign of Henry, king of the English, for a space of 139 years $(\S 52)$.

Similar notices occur in the summary histories among the prelims to Chronica chronicarum, most notably those concerned with Kent, East Anglia and Northumbria. ${ }^{56}$ They are also a feature of the common root that lies behind the Winchcombe and Coventry Chronicles, a chronicle that also seems to have originated at Worcester Cathedral. ${ }^{57}$ The author of De primo Saxonum aduentu records, in contrast, the regnal years of individual reigns, but says nothing about the durations of particular kingdoms and episcopal sees. ${ }^{58}$

There are, admittedly, textual affinities that point to links with other houses, but none that cannot be reconciled with production at Worcester. It is striking, for instance, that Cronica de Anglia's entry about the establishment of monks at Bury St Edmunds ( $\S$ 62) echoes that abbey's accounts of how Abbot Baldwin (1065-97×98) prevented Bishop Herfast of East Anglia (1070-84) making their church the seat of his bishopric. The entry says that

on the unanimous advice of his archbishops, bishops and magnates, King Cnut ejected from the church of St Edmund, king and martyr, the priests who were living there without a rule and installed monks there. On the order of the same king Archbishop Æthelnoth, archbishop of Canterbury, dedicated that very church and established an abbot, whom Faldwine [sic], bishop of London, consecrated.

These details echo the arguments which were used to defeat Herfast - according, that is, to Bury's records of what happened in the legal proceedings at Winchester in May 1081. The charter which records the judgement - a charter which almost certainly improves that which William I had actually issued, but which was devised within a decade or two of the event — describes how Abbot Baldwin responded to Herfast by narrating how ${ }^{59}$

\footnotetext{
56 JWKings (C, pp. 48, 49 and 51), printed in Benjamin Thorpe, Florentii Wigorniensis Monachi Chronicon ex Chronicis, English Historical Society Publications 13, 2 vols. (London, 1848-9), 1:260, 262, $270-1$.

57 Winchcombe Chronicle, s.a. 823, 861, 870, ed. Hayward, Winchcombe and Coventry (n. 26 above), 2:355-543, at 472,480 .

${ }^{58}$ E.g. Arnold, Symeonis Opera Omnia, 2:373: "Cnut regnauit fere xix. annis. Cui successit Haroldus, eius ex concubina filius, regnans v. annis. Post quem Hardecnud, filius Cnutonis et Emmæ, frater Eadwardi, qui regnauit ii. annis, xv. diebus minus...."

${ }^{59}$ Regesta regum Anglo-Normannorum: The Acta of William I (1066-1087), ed. David Bates (Oxford, 1998), no. 39 (p. 206): "Abbas uero e contra, quomodo Canutus rex a predicta ecclesia cum communi consilio archiepiscoporum, episcoporum et optimarum suorum presbiteros qui inibi inordinate uiuebant eiecerit et monachos posuerit. Quoadque
} 
on the unanimous advice of his archbishops, bishops and magnates, King Cnut ejected from the aforesaid church the priests who were living there without a rule and installed monks there; and how on the orders of the same king Archbishop Æthelnoth of Canterbury then dedicated that church and how the bishop of London blessed the first abbot of that place, the bishop of Winchester the second, and the archbishop of Canterbury Baldwin, who was the third abbot; and how for fifty-three years the monks of the aforesaid place received ordinations from bishops whom they chose without the objection of any of the aforesaid Herfast's predecessors.

In their efforts to provide effective defences against Herfast's successors the monks of Bury had developed, in short, a narrative which implied that they were not dependent on their diocesan for the performance of consecrations and ordinations. ${ }^{60}$ Cronica de Anglia's inclusion of this material might be construed as evidence that its author was based at Bury, but it is most unlikely that its library could have furnished the author with all of the materials that he used. To be sure, Bury owned a relatively advanced copy of John's Chronica chronicarum, ${ }^{61}$ but there is no sign, for example, that it owned a copy of his Chronicula. ${ }^{62}$ Cronica de Anglia's account of the founding of Bury is best read, therefore, as evidence that Worcester had a copy of either the 1081 judgement or of some other narrative that

postmodum ipsam ecclesiam Ægelnodus archiepiscopus Cantuariensis iussu prelibati regis dedicauerit atque primum abbatem loci illius episcopus Lundoniensis secundum episcopus Uuintoniensis, ipsum etiam Balduuinum qui tertius est abbas archiepiscopus Cantuuariensis sacrauerit, et quia per LIII annos sine alicuius iamdicti Arfasti antecessoris contradictione monachi predicti loci a quibus uoluerunt episcopis ordines susceperint ex ordine luculenter enarrauit." On the authenticity and date of this diploma, see the discussion in ibid., 202-5; idem, "The Forged Charters of William the Conqueror and Bishop William of St Callais," in David W. Rollason, Margaret Harvey and Michael Prestwich (eds), Anglo-Norman Durham, 1093-1193 (Woodbridge, 1994), 111-24.

${ }^{60}$ This narrative would seem to have emerged after the Conquest, in the 1080s or 1090s. Certainly, an exemption from this aspect of diocesan authority is not specified in the bull Quamquam sedes which Abbot Baldwin obtained from Alexander II in 1071 (JL 4692, ed. Francis Hervey, The Pinchbeck Register, 2 vols. (Brighton, 1925), 1:2-4; JWCC, 2:647-8) or in the foundation charter attributed to Cnut (S 980, ed. C. W. Goodwin, "On Two Ancient Charters in the Possession of the Corporation of Kings Lynn," Norfolk Archaeology 4 (1855): 93-117, at 108-11), though the earliest version of this doument probably dates from the same period (see Kathryn A. Lowe, "Bury St Edmunds and its Liberty: A Charter-Text and its Afterlife", English Manuscript Studies 1100-1700 17 (2013): 155-72 (esp. 155-60)). Cnut's charter frees the house "eternally from the dominion of every bishop of that shire"; Alexander's bull places the monastery under papal protection, prohibits its conversion into an episcopal see, and anathematizes anyone who would dare to disturb its monks and their possessions. The bull granted in 1123 by Pope Calixtus II is the earliest to specify that the monks were allowed to receive consecrations, ordinations and other episcopalia from the bishop of their choice (JL 7074, ed. Walther Holtzmann, Papsturkunden in England, 3 vols., Abh. Göttingen, neue Folge 25, dritte Folge 14-15 and 33 (Berlin, 193052), 3:131-3). Note also that the charter attributed to Harthacnut (S 995, ed. Goodwin, "Two Ancient Charters," 113-7) prohibits archbishops and bishops celebrating masses, doing justice, or exercising any form of lordship over the monks, clerics or laypeople of the abbey, but it is not explicit about the blessing of its abbots and it was probably forged during the reign of Henry I. Cf. Antonia Gransden, "Baldwin, Abbot of Bury St Edmunds, 1065-1097," Anglo-Norman Studies 4 (1982): 65-76, at 70-72.

${ }^{61}$ Oxford, Bodleian Library, MS Bodley 297. It should be noted that a copy of the 1081 charter also appears among the many interpolations that were inserted into Chronica chronicarum at Bury: see JWCC (B), 3:310-2 (s.a. 1081). A few echo of Cronica de Anglia, § 62, also occur in the accounts of the reform and dedication of the church at Bury that were interpolated under the years 1020 and 1032: ibid., 2:643.

${ }^{62}$ See Richard Sharpe, "Reconstructing the Medieval Library of Bury St Edmunds Abbey: the Lost Catalogue of Henry Kirkstead," in Antonia Gransden (ed.), Bury St Edmunds: Medieval Art, Architecture, Archaeology and Economy, British Archaeological Association Conference Transactions 20 (Leeds, 1998), 204-18 (esp. 211); Rodney M. Thomson, "The Library of Bury St Edmund's Abbey in the Eleventh and Twelfth Centuries," Speculum 47 (1972): 617-45 (esp. 641-3). 
made detailed use of it. ${ }^{63}$ There are, as it happens, good grounds for thinking that Worcester owned one of the surviving copies of the charter — that found in BL Cotton MS Otho A.XVIII, fol. 132v; and its script suggests that it was made in the second quarter of the twelfth century, the period in which Cronica de Anglia was compiled. It is most unfortunate, therefore, that this copy was so badly damaged in the fire of 1731 that most of the text is beyond recovery. ${ }^{64}$

The aspect of Cronica de Anglia that counts most strongly against production at Worcester is its Dionysian chronological apparatus. For all the twelfth-century chronicles which are known to have been compiled at the Cathedral Priory used the revised AD dating system developed by Marianus Scotus. An Irishman who settled in the Rhineland as a "pilgrim for Christ", Marianus wrote his Chronica chronicarum in an attempt to provide a coherent solution to the chronological problems in the Christian theory of world history, the primary issue being to establish the correct date of the Incarnation. In his view the birth of the Saviour had taken place some twenty-two years earlier than Dionysius Exiguus had reckoned, and his third book - a chronicle of the Sixth Age of the World which runs from the Incarnation to 1076 in his first version — is concerned with finding the extra twenty-two years required to make this theory work. ${ }^{65}$ In this section Marianus plots the passage of time with a three-fold apparatus: he notes, first, the year of Lord according to the uerior assertio, his "truer chronology", second, the year of the current Roman Emperor, and third, the year of the Lord according to Dionysius. ${ }^{66}$ John of Worcester retained this system in his version of the same

\footnotetext{
${ }^{63}$ Cf. Herman of Bury, Miracula S. Eadmundi (BHL 2395-6), §§ 25-29, ed. Thomas Arnold, Memorials of St Edmund's Abbey, RS 96, 3 vols. (1890-96), i, 26-92, at 60-67. Writing apparently after the death in 1097/8 of Abbot Baldwin, who is described in the prologue as being of felix memoria, Herman used the charter of William I for his account of the 1081 trial, but he selects somewhat different words and adds details such as the names of the first two abbots, Ufi and Leofstan - details which would probably have crept into $\S 62$ of Cronica de Anglia if its author had used it. Similar material, devoid however of telling verbal echoes, also appears in the margins of the Easter Tables of the Bury Psalter, alongside the years 1019 and 1032: Vatican City, Bibliotheca Apostolica Vaticana, MS Reg.lat. 12, fols. 16v and 17v (cf. Edward Maunde Thompson, John A. Herbert and Harold Idris Bell (eds), The New Palaeographical Society Facsimiles of Ancient Manuscripts: Second Series, 2 vols. (London, 1913-30), pls. 166-8).

${ }^{64}$ Cf. Charters of Sherborne, ed. Mary A. Ó Donovan, Anglo-Saxon Charters 3 (Oxford, 1988), xviii-xix; Acta of William I (1066-1087), 205.

${ }^{65}$ Book three was printed by Georg Waitz in MGH Scriptores, vol. 5 (1864), 481-562, but the conception and organisation of the work is best grasped by consulting the surviving manuscripts: (1) Vatican City, Biblioteca Apostolica Vaticana, MS Pal. lat. 830; (2) BL Cotton MS Nero C.V, fols. 27r-159r. For an excellent overview of Marianus's project, see Peter Verbist, Duelling with the Past: Medieval Authors and the Problem of the Christian Era (c.990-1135), Studies in the Early Middle Ages 21 (Turnhout, 2009), 85-143. See also idem, "Reconstructing the Past: The Chronicle of Marianus Scottus," Peritia 16 (2002): 284-334; idem, "Abbo of Fleury and the Computational Accuracy of the Christian Era," in Gerhard Jaritz and Gerson Moreno-Riano (eds), Time and Eternity: The Medieval Discourse (Turnhout, 2003), 63-80; Anna Dorothee von den Brincken, "Marianus Scottus als Universalhistoriker iuxta veritatem Evangelii", in Heinz Löwe (ed.), Die Iren und Europa im früheren Mittelalter, 2 vols. (Stuttgart, 1982), 2:970-1009.

${ }^{66}$ E.g. Marianus places the election of Pope Gregory the Great in the 615 th year of the uerior assertio (numbered in red ink); in the 11th year of Maurice, the 62nd emperor of the Romans; and the 593rd year of the Dionysian era, the final date having been assigned to the other side of the annal. This is the arrangement in the autograph, Pal. lat. 830, fol. 151v;
} 
chronicle. ${ }^{67}$ Employing a simplified version of this apparatus, the lost set of annals behind the Winchcombe and Coventry chronicles - another Worcester product — ordered its factoids using two columns of numbers, the first giving the year according Marianus, the other that according to Dionysius. ${ }^{68}$ John's Chronicula lumps its material together in long entries and allocates them to widely-spaced chronological anchors in something like the manner of Bede's Chronica maiora. Yet these anchors are not years of the world, but the years of the Sixth Age according to Marianus. ${ }^{69}$ Given the consistency of Worcester's commitment to the Marianan position, it is an issue that Cronica de Anglia dates its events by reference to "the year of the Lord" alone and that it allocates them to the expected Dionysian years or thereabouts. It would not, however, have been difficult for a scribe to revise the dating system, especially if the exemplar correlated its factoids with the usual Dionysian date as well as its Marianan counterpart. He would merely have had to delete the latter component. It is not unlikely, furthermore, that a scribe based at Rievaulx, a bastion of the new monasticism, would have taken such an approach, because in the late twelfth century conservative voices were turning, as will emerge below, against chroniclers who questioned the received Dionysian chronology.

So, to bring this part to a conclusion, although Cronica de Anglia survives solely in a manuscript which belonged to Rievaulx and which was probably made there, its textual affinities and the many internal indications as to when and where it was compiled strongly suggest that it was produced in southern England, probably at a religious house in the West Midlands, if not, as seems almost certain, at Worcester Cathedral Priory itself. Indeed, the many similarities in method, style, and attitude to the known works of John of Worcester suggest that it comprises another product of his historical workshop - if not of the man himself. John's career certainly encompasses the period when the Chronica was produced: he began work well before 1119 and he was still active in 1141 and perhaps for several years afterwards. ${ }^{70}$ It is difficult to avoid thinking that he played some role in the production of this chronicle.

\footnotetext{
in Nero C.V, fols. $142 \mathrm{v}-143 \mathrm{r}$, the first two items are reversed.

${ }^{67}$ E.g. Corpus 157 , p. 255 . Here the order of the numerals is the same as in Pal. lat 830, but John has modified Marianus by assigning the election of Gregory I to the year 614/592.

${ }^{68}$ Both chronicles are edited in Hayward, Winchcombe and Coventry (n. 26 above), 356-543 and 546-701.

${ }^{69}$ E.g. JWChronicula, G, fols. $48 \mathrm{r}-49 \mathrm{v}$, where the papacy of Gregory I is covered within a long entry that begins "in the year of the Lord 604". That year was the first of the Emperor Maurice's reign according to Marianus's revised chronology, and the entry covers the whole of his reign as emperor. According to the Dionysian system Maurice ruled from $\mathrm{AD} 582$ to 602 .

${ }^{70}$ See Hayward, Winchcombe and Coventry (n. 26 above), 64-65, 76.
} 


\section{JOHN OF WORCESTER AND CRONICA DE ANGLIA}

Liebermann rightly recognised that Cronica de Anglia depends in part on John of Worcester's work, but he failed the realise just how closely they were related. He missed, for example, a number of clear textual echoes. ${ }^{71}$ Indeed, much of the material which he thought came from Bede's Historia ecclesiastica was probably derived via Chronica chronicarum and its auxiliary matter. ${ }^{72}$ There are just three sentences - found in $\S \S 3,10$ and 19 - that seem to depend directly on Bede. Lieberman was also unaware of the extent of Cronica de Anglia's relationship to the Chronicula. To be sure, he noticed that some of Cronica's borrowings from William of Malmesbury's Gesta pontificum echo the extracts from this source that John of Worcester inserted into the partial autograph of Chronica chronicarum (Oxford, Corpus Christi College, MS 157, usually known as "C"). ${ }^{73}$ This was an acute observation, given how little was understood about the evolution of Chronica chronicarum and the relationship between John and his assistant Florence in the late nineteenth century; ${ }^{74}$ but much more needs to be said about these parallels and their implications.

In Cronica de Anglia material that echoes Gesta pontificum is distributed across thirty-three sections; ${ }^{75}$ in Chronica chronicarum there are two "layers" of borrowings from this source. They appear in the form of more than sixty short notes and narratives which were inserted into the autograph by " $\mathrm{C}^{3 \text { ", }}$, the scribe who is thought to be John himself — in margins, in spaces at the ends of annals, and in gaps created through erasure and re-writing. A few of these items were added to the

\footnotetext{
${ }^{71}$ E.g. Chronica de Anglia, $\S 72$, on the foundation of Hyde Abbey. The source, which Liebermann missed, is JWCC, s.a. 1111. Cf. also d'Arcier, Histoire et géographie d'un mythe (n. 4 above), p. 53, who misleadingly describes Chronica de Anglia as a chronicle 'close to that of William of Malmesbury'.

${ }^{72}$ The direct source, for example, of Chronica de Anglia, § 1, was not Bede, HE, 5.24 (p. 562), as Liebermann suggested in $A N G, 16$, but JWCC (MS C, p. 217), s.a. 162. The section on Aidan and Lindisfarne depends, likewise, not on Bede, $H E, 3.3$ (pp. 218-20), and WMGP, 3.126.1, as Liebermann suggested in $A N G, 17$, but on JWBishops (C, p. 45) and JWCC, s.a. 995.

${ }^{73}$ I say "partial autograph" because $\mathrm{C}$ began life as a fair copy made about a half-to-two-thirds of the way into the process of compiling Chronica chronicarum. It conflates the initial stages of composition (between $c .1095$ to $c .1131$ ), while the modifications and additions, though numerous, bear witness only to the final stages of the process (between c.1131 and c.1143). For a fuller explanation, see Martin Brett, "John of Worcester and his Contemporaries," in Ralph H. C. Davis and John M. Wallace Hadrill (eds), The Writing of History in the Middle Ages: Essays presented to Richard William Southern (Oxford, 1981), 101-26; Hayward, Winchcombe and Coventry (n. 26 above), 64-76; and McGurk's introductions to JWCC, 2:xvii-lxxxi, and 3:xv-1.

${ }^{74} A N G, 16$, citing passages that have now been printed in JWCC, s.a. 629, 633. Benjamin Thorpe suppressed the marginalia in his edition, Florentii Chronicon ex Chronicis. On the authorship of the Chronica chronicarum, and the Florence's role in the project, see McGurk in JWCC, 2:xvii-viii; Brett, "John of Worcester," 104, 111-12; and Hayward, Winchcombe and Coventry (n. 26 above), 64-65.

${ }^{75}$ Chronica de Anglia, $\S \S 4,17,22,25,29,32-35,38-46,49,52,55,56,58,64,66-67,75-81$.
} 
autograph soon after it was made — that is, after 1131 and in the early 1130s. Thus, these items figure in all the other manuscripts now extant, except for the Evesham fragment. ${ }^{76}$ Most of the borrowings from Gesta pontificum were added, however, at a slightly later stage — in the mid-to-late 1130s. This much is implied by their appearance, usually in the main body of the text, in the two copies that depend on a more advanced form of the autograph - in the copy that was made for Bury (Oxford, Bodleian Library, MS Bodley 297, usually known as "B") and in that which came to Peterborough (Cambridge, Corpus Christi College, MS 92, fols. 1r-167v, usually known as "P"). ${ }^{77}$ As Liebermann perceived, ${ }^{78}$ John of Worcester seems to have been adding much the same material to his autograph at around the same time as Cronica de Anglia was produced or, more likely perhaps, soon afterwards.

At first sight it appears as though Chronica de Anglia took most of the passages that repeat parts of Gesta pontificum from the marginalia in John's autograph. The marginalia are usually fuller than the corresponding items in Cronica de Anglia, and they often mirror the ways in which John has arranged and abbreviated the source. Consider, for example, the entry about Tavistock $(\S 49)$ :

Cenobium in Domnania quod Theauestoca uocatur, iuxta Tay fluuium situm, Orgatus comes Domnaniensis, pater Elfridę uxoris regis Ædgari, constituit.

Gesta pontificum has a very similar passage: ${ }^{79}$

Est in Domnonia cenobium monachorum iuxta Taui fluuium, quod Tauistoch uocatur, quod per Ordgarum comitem Domnoniensem, patrem Elfdridae, quae fuit uxor regis Edgari, surgendi exordium, per Liuingum episcopum crescendi accept auspitium.

But the marginalia provide a closer echo: ${ }^{80}$

Cenobium in Domnania quod Teauistok uocatur, iuxta Tau fluuuium situm, Orgarus comes Domnaniensis, pater Ælfthrythe uxoris regis Eadgari construxit.

The author of Cronica de Anglia might well have derived this item and many others from John's

\footnotetext{
${ }^{76}$ E.g. (1) JWCC, s.a. 675 , where material about Barking and Chertsey, derived in part from WMGP, 2.73.11-15 and added by $\mathrm{C}^{3}$ to the margin of $\mathrm{C}$, has passed into all the other witnesses; (2) JWCC, s.a. 932, where material about St Byrnstan, derived from WMGP, 2.75.24, and added by $\mathrm{C}^{3}$ to the margin of $\mathrm{C}$, has passed into all the other witnesses.

${ }^{77}$ Borrowings from WMGP which appear in all three manuscripts (CBP) figure in the most recent edition, JWCC, under the years $463,481,543,629,633,644,652,653,661,666,667,678,685,688,705,734,736,744,745,748,781$, $789,828,836,867,880,882,885,897,909,920,932,934,937,957,959,961,972,976,990,1013,1038,1043,1052$, $1061,1070,1094,1123$. Borrowings which appear only in C and B appear under 790, 862, 988, 1048, 1050, 1051, 1070, 1091, 1095, 1111. On this strand of material and its place in the manuscript tradition, see JWCC, ii, pp. lii-liii and lviii; Brett, "John of Worcester," 107-9, 122; Hayward, Winchcombe and Coventry (n. 26 above), 68-71.

${ }^{78} A N G, 16$.

${ }^{79} \mathrm{WM} G P, 2.95 .1$.

${ }^{80} \mathrm{JWCC}\left(\mathrm{C}^{3} \mathrm{BP}\right)$, s.a. 961.
} 
autograph, ${ }^{81}$ but there are a number of exceptions to this pattern — passages where Cronica reports Gesta pontificum more fully than John's marginalia. The passage about Wilton ( $(55)$ provides a straightforward example:

Wiltunense cenobium beata Edgitha filia regis Edgari, dulcibus exuuiis ornat. Wiltune est uicus non exiguus, super Wille fluuium positus, tantę celebritatis, ut totus pagus ab eo uocetur.

The marginalia in the autograph provide a partial match: ${ }^{82}$

Wiltunense cenobium beata Edgitha filia regis Edgari, dulcibus exuuiis ornat.

But Gesta pontificum has every word: ${ }^{83}$

Wiltunense cenobium beata Edgitha filia regis Edgari, sedem ossuum suorum dulcibus exuuiis ornat, amore fouet. Wiltuna est uicus non exiguus, supra Wile fluuium positus, tantae celebritatis ut totus pagus ab eo uocetur.

The author of Cronica de Anglia could not have derived this passage from Chronica chronicarum alone - or rather, he could not have done so on the evidence of the surviving manuscripts. The same is true of another fourteen passages in Cronica de Anglia that echo the marginalia in Corpus 157, John's autograph. ${ }^{84}$ It is possible that some of these passages might have been generated by collating the marginalia with Gesta pontificum. ${ }^{85}$ The author certainly seems to have made direct use of Gesta pontificum for the lengthy passage about the 1075 Council of London ( $\$ 67),{ }^{86}$ and perhaps also for a few shorter items (e.g. $\S \S 4,40$ ). But with the many short entries where there are overlapping parallels to both the marginalia in Chronica chronicarum and Gesta pontificum, it would have been a complicated process to repeat John's work all over again. It seems much more likely that a lost intermediary lies between the three texts — that is, a set of "working notes" that John took from Gesta pontificum and a somewhat fuller version of this material than is preserved in the surviving

\footnotetext{
${ }^{81}$ E.g. Cronica de Anglia, $\S \S 6,7,17,22,25,33,34,38,41,42,44,64,76,77,80,81$.

82 JWCC $\left(\mathrm{C}^{3} \mathrm{BP}^{3}\right)$, s.a. 1043 .

${ }^{83}$ WMGP, 2.87: "The blessed Edith, daughter of King Edgar, ornaments the monastery at Wilton, the seat of her bones, with her sweet trappings - she caresses it with her love. Wilton is a not insignificant village, placed on the River Wylye, of such renown that the entire county is named after it." Cf. Prudentius, Peristephanon, 3.5, ed. H. J. Thompson, Poems, Loeb Classical Library, 2 vols. (London, 1939-53), 2:98-345, at 142.

${ }^{84}$ Cronica de Anglia, $\S \S 29,32,35,39,43,45,46,52,55,56,58,75,78,79$.

${ }^{85}$ Cronica de Anglia, $\S 39$ is so much fuller in its use of Gesta pontificum that it lends itself to this hypothesis: the author could have collated WMGP, 2.94.1-7 $\beta$ with the items taken from JWCC $\left(\mathrm{C}^{3} \mathrm{BP}^{3}\right)$, s.a. 909 , 972, and JWCC, s.a. 1031 and 1046.

${ }^{86}$ But the long entry about the primacy $(\S 66)$ depends, not on WMGP, i.27, but on William of Malmesbury, Gesta regum Anglorum, 3.298.1-6, ed. and trs. R. A. B. Mynors, Rodney M. Thomson and Michael Winterbottom, 2 vols., OMT (1998-9), cited hereafter as "WMGR", 1:530-2.
} 
elements of John's corpus. Shared reliance on such a set of notes would also help to explain the somewhat disordered way in which Cronica de Anglia and John's marginalia report this strand of material.

There are, furthermore, a number of items where Cronica de Anglia provides a version of John's material that seems to sit "behind" or "between" two or more passages in the complex of materials that make up Chronica chronicarum and Chronicula. Its account, for example, of the division of Mercia into five episcopal sees $(\S 20)$ is closely related to those found in Chronicula and in the short history of Worcester Cathedral that appears among the prelims to Chronica chronicarum. But it has one phrase that echoes only the former - the phrase "constructor et abbas monasterii quod Medeshamstede dicitur ${ }^{\prime 87}$ — and another that echoes only the latter — the phrase "in quinque parrochias diuisa est" ${ }^{88}$ Verbal parallels to $\S 20$ also occur in the note about the division of Mercia into five bishoprics that was inserted into margins of the autograph, alongside the annals for 679 to 682 in the main body of Chronica chronicarum, but this version of the material is much briefer than the other four. ${ }^{89}$ All of this invites speculation as to whether Cronica de Anglia was a source for the other three versions, but this seems unlikely because Chronicula and the short history of the cathedral are both fuller and each of them arrange the material in their own way. Some sort of lost intermediary would seem to lie behind all of these variants. Several items in Cronica de Anglia exhibit this sort of pattern of "overlapping" relationships with various elements in John's corpus, ${ }^{90}$ suggesting that its author had access, not merely to "the library" of Worcester Cathedral (as Liebermann suggested), ${ }^{91}$ but to John's working drafts - that it should be understood as a "re-arrangement" or "reconceptualisation" of those materials for a new purpose. Cronica de Anglia provides, then, further evidence that an obsession with rearranging material, with reshuffling data for aesthetic and other reasons, was a marked feature of the historical atelier over which John of Worcester presided. ${ }^{92}$

\footnotetext{
${ }^{87}$ JW Chronicula (fol. 52rv).

${ }^{88} \mathrm{C}$, fol. $1 \mathrm{r}$.

${ }^{89} \mathrm{JWCC}\left(\mathrm{C}^{3} \mathrm{BP}\right)$, s.a. 679.

${ }^{90} \mathrm{Cf}$. Cronica de Anglia, $\S \S 36,56,57,63,65,69,83,84,85$ and the notes below.

${ }^{91}$ Liebermann, $A N G, 15$.

${ }^{92}$ Cf. Hayward, Winchcombe and Coventry (n. 26 above), esp. 78-79: "the systematic re-arrangement of borrowings whilst preserving much of their vocabulary is one of the defining traits of John's compositional method". See also McGurk's comments in the introduction to JWCC, 2:1xxviii, about John's editing and re-organisation of the annals in the margins of the Easter Tables that were part of Marianus Scotus's Chronica chronicarum.
} 


\section{The Historical Value of CRONICA DE ANGLIA}

The Cronica de Anglia is sometimes cited, typically by reference to Liebermann's synopsis, for a few otherwise unattested factoids. One often cited entry is the claim that King Offa (757-96) founded a convent at Winchcombe: "In the year of the Lord 787, Offa built a monastery in the province of Gloucester, in the place which is called Winchcombe, in which he installed nuns" (§32). This factoid is at odds with the abbey's own traditions, which imply that King Cenwulf (798-821) alone was responsible for founding the monastery, ${ }^{93}$ but there might be something in it. A number of leading historians have thought that the abbey was established in two stages - that Cenwulf took over a project that Offa had begun. ${ }^{94}$ Levison and Sims-Williams found support for this theory in the fact that the local parish church was dedicated to St Peter and in the evidence provided by the Winchcombe Sacramentary that the monks of the pre-Conquest considered this saint to be one of their patrons, because Offa is known to have had a policy of dedicating his foundations to this apostle. ${ }^{95}$ That the parish church was part of the pre-Conquest minster complex and that Peter was one of the patron saints of the ninth-century minster is plausible enough. Earlier Anglo-Saxon minsters often had several free-standing churches, ${ }^{96}$ and earlier dedications to St Peter were often marginalised in the late

\footnotetext{
${ }^{93}$ See Goscelin of St Bertin, Vita S. Kenelmi, regis et martyris $($ BHL $4641 \mathrm{n}+\mathrm{p}+\mathrm{r}), \S 17$, ed. R. C. Love, Three Eleventh-Century Anglo-Latin Saints' Lives, OMT (1996), 50-88, at 72, where Winchcombe is described as the "monastery of the saint's father", Cenwulf; and the foundation charters preserved in the Winchcombe Chronicle (n. 57 above), s.a. 811 and 818 (2:454-63 and 470-73). All of the latter documents were re-worked or interpolated with extraneous material, but all seem to rest on authentic traditions of some kind: see the discussion in ibid., 1:251-64 and 270. It should also be noted that the item presently under discussion contaminated the abbey's traditions in the late twelfth or thirteenth century, when it was inserted into the margins of the Winchcombe Chronicle, s.a. 787.2 (2:450), a later echo which suggests that the Cronica de Anglia circulated in the diocese of Worcester: see also ibid., 1:246.

${ }^{94}$ E.g. John Blair, The Church in Anglo-Saxon Society (Oxford, 2005), 122, 288; Sarah Foot, Veiled Women, Studies in Early Medieval Britain, 2 vols. (Aldershot, 2000), 2:239.

${ }^{95}$ Wilhelm Levison, England and the Continent in the Eighth Century (Oxford, 1946), 31, 257-59; Patrick SimsWilliams, Religion and Literature in Western England, 600-800, Cambridge Studies in Anglo-Saxon England 3 (Cambridge, 1990), 165-6. For the church of St Peter, see also Stephen R. Bassett, "A Probable Mercian Royal Mausoleum at Winchcombe, Gloucestershire," The Antiquaries Journal 65 (1985): 82-100 (esp. fig. 1); for the Sacramentary, the circumstances of its production, and the prominence of St Peter in its litany (his name is written in majuscules and a threefold invocation), see The Winchcombe Sacramentary (Orléans, Bibliothèque municipale, MS 127 [105]), ed. Anselme Davril, HBS 109 (Woodbridge, 1995), 261, together with Michael Lapidge, "Abbot Germanus, Winchcombe, Ramsey and the Cambridge Psalter," in Michael Korhammer (ed.), Words, Texts and Manuscripts: Studies in Anglo-Saxon Culture presented to Helmut Gneuss on the Occasion of his Sixty-Fifth Birthday (Woodbridge, 1992), 99129 (esp. 103-6).

${ }^{96}$ See Helen B. Gittos, Liturgy, Architecture, and Sacred Places in Anglo-Saxon England, Medieval History and Archaeology (Oxford, 2013), 55-102. See also John Blair, 'Anglo-Saxon Minsters: A Topographical Review', in John Blair and Richard Sharpe (eds), Pastoral Care Before the Parish (Leicester, 1991), 226-66 (esp. 246-58); Blair, Church in Anglo-Saxon Society (n. 94 above), 196-204; Rosemary Cramp, Wearmouth and Jarrow Monastic Sites, 2 vols. (Swindon, 2005), esp. 1:349-50, 354-6.
} 
tenth and early eleventh centuries, owing to the monastic reformers' preference for saints such as the Virgin Mary - for saints who stood for virginity and the monastic order as opposed to those who were identified with the secular clergy. ${ }^{97}$ Offa's policy of assembling a network of monasteries dedicated to St Peter is revealed, finally, by a privilege of Pope Hadrian I (772-95) which was preserved in Liber diurnus, a collection of formulas which, though not the actual formulary of the papal chancery, contains many that were used in making of papal documents in the eighth and ninth centuries. This privilege says that the monasteries which the king had built or acquired and dedicated to his patron, the blessed Peter, were to remain under his authority, that of his wife Cynethryth, and that of their descendants. ${ }^{98}$ Bath and Cookham, both located at the southern limits of Mercian territory, are two monasteries that were assimilated under this policy. ${ }^{99}$ The Winchcombe factoid fits neatly, in short, into the little that is known about Offa's monastic strategy, and it has allowed historians to develop a richer scenario for the early history of the abbey and to dispel a little of the obscurity that surrounds the history of Mercia in the late eighth and early ninth century.

Yet aspects of Cronica de Anglia's coverage of Winchcombe's history provide grounds for caution. Its notice, for example, about Cenwulf's role in the history of the abbey shows an element of fabrication: it is largely taken from the account in Gesta pontificum - an account which is itself based on the "semi-authentic" foundation charter attributed to Cenwulf. ${ }^{100}$ The Cronica's entry differs, however, in one striking detail. Whereas William states that Cenwulf built and dedicated the abbey with "with huge generosity, incredible to our age" (ingens et nostris temporibus incredibilis munificentia), the entry in Cronica de Anglia says that "he assembled [there] monks three hundred in number" ( $(32)$. It is hard not to infer that this detail was invented. It replaces vague praise (or sarcasm?) with a precise but fanciful claim. No English monasteries had so many monks at this

\footnotetext{
${ }^{97}$ At Worcester, for example, the church of St Mary built by Bishop Oswald gradually eclipsed the older cathedral church of St Peter: see Julia S. Barrow, "The Community at Worcester, 961-c.1100," in Nicholas P. Brooks and Catherine Cubitt (eds), St Oswald of Worcester: Life and Influence, Studies in the early history of Britain (London, 1996), 84-99 (esp. 89-91); Nigel Baker and Richard Holt, Urban Growth and the Medieval Church: Gloucester and Worcester (Aldershot, 2004), 134-5. For the identification of St Peter with the secular clergy, see Catherine Cubitt, "Images of St Peter: The Clergy and the Religious Life in Anglo-Saxon England", in Paul Cavill (ed.), The Christian Tradition in AngloSaxon England, Christianity and Culture: Issues in Teaching and Research (Woodbridge, 2004), 41-54 (esp. 45-50).

${ }^{98}$ Vatican City, Archivio Segreto Vaticano, MS Misc. Arm. XI.19, ed. Hans Foerster, Liber diurnus Romanorum pontificum (Bern, 1958), no. 93.

${ }^{99}$ Levison, England and the Continent (n. 95 above), 29-31; Sims-Williams, Religion and Literature (n. 95 above), 159-65; Pauline Stafford, "Political Women in Mercia, Eighth to Early Tenth Centuries," in Michelle P. Brown and Carol A. Farr (eds), Mercia: An Anglo-Saxon Kingdom in Europe (London, 2001), 35-49, at 40.

${ }^{100} \mathrm{WMGP}, 4.156 .1-2$. The earliest of the surviving version of the foundation charter is found in the Winchcombe Chronicle (n. 57 above), s.a. 811 (pp. 456-63). On the authenticity of the charter, see ibid., 258-64.
} 
time, ${ }^{101}$ and it is easy to see how the figure might have been suggested by the entries for Gloucester and Pershore - entries which precede it in the text and which state that these houses were endowed with the land of "three hundred tributaries" ( $\S 23-24)$. If the author could fabricate this kind of detail, then he might also have invented the otherwise unattested claim that King Offa founded a convent at Winchcombe.

Still, the Cronica de Anglia should not be considered worthless - far from it. Its true value lies, not in the reliability of the factoids that it purports to record, but in its connections with other texts and in what they reveal about the culture of the twelfth-century monastery - the milieu in which many of the records on which we depend for our knowledge of the period were produced and consumed. It provides evidence, that is, for the preoccupations of the writers who recorded our data - evidence which allows us to build a fuller picture of their values and which enhances our ability to compensate for the ways in which their narratives and perspectives distort our understanding of the period.

It is telling, for example, that Chronica de Anglia tames the material which it takes from William of Malmesbury, erasing his provocations and satire. Its coverage, for example, of the founding of St Albans omits the comment that the saint was "neither a mercenary nor a pointless martyr", faint praise that contains more than a hint of sarcasm. ${ }^{102}$ It omits, likewise, the insinuation that God deprived William Warelwast of his sight because he had circulated gossip about Bishop Osbern's blindness as a way of trying to bring about his resignation. Whereas Gesta pontificum says that he bore "the price of his ambition, utterly deprived of the sight of his eyes, though otherwise whole and in the flush of youth", ${ }^{103}$ Cronica de Anglia erases the criticism by saying that he is "now completely deprived of the sight of his eyes, not yet elderly, no matter how unfortunate" (§ 39). It omits, similarly, William's aspersions about John of Tours, bishop of Wells (1088-1122), the suggestions that he made not a little money as a doctor and that he moved the seat of his bishopric to Bath because he considered it "beneath his glory" to reside in a village. ${ }^{104}$ The alteration, likewise, to William's account of the foundation of Winchcombe Abbey was also made to erase an insinuation, for Gesta pontificum implies that Cenwulf”s “enormous generosity" (ingens munificentia) was grossly

\footnotetext{
${ }^{101}$ The largest community attested in the historical record comprises the ninety monachi who were martyred at Chertsey when "heathens" raided the monastery: Secgan be pam Godes sanctum, pe on Engla lande cerost reston, § 49, ed. Felix Liebermann, Die Heiligen Englands (Hannover, 1889), 9-20, at 19-20. On the earliest manuscript, BL Stowe 944, fols. 36v-39r, which was copied in 1031, see Simon D. Keynes, The Liber Vitae of the New Minster and Hyde Abbey, Winchester (British Library Stowe 944), Early English Manuscripts in Facsimile 26 (Copenhagen, 1996), 37-38.

${ }^{102}$ Cf. WMGP, 4.179.1, with JWCC (C ${ }^{3}$ B), s.a. 1048, and Cronica de Anglia, §§ 32, 79.

${ }^{103} \mathrm{WMGP}, 2.94 .1-7 \beta$.

${ }^{104} \mathrm{WMGP}$, 2.90.2. Cf. Cronica de Anglia, § 38; JWCC $\left(\mathrm{C}^{3} \mathrm{BP}^{3}\right)$, s.a. 1091.
} 
misdirected. William goes on to allege that at the dedication he gave countless precious gifts to his magnates and "a pound of silver to everyone who had no fields", before going on to say that the monastery was scarcely more than a name by King Edgar's reign — "mortal things always sliding downhill". ${ }^{105}$ The implication is that Cenwulf should have used his wealth, not to fund such a splendid ceremony, but to secure sufficient resources for the monastery to ensure its long-term survival - a theme to which William often returns. ${ }^{106}$ But Cronica de Anglia emasculates this material, reducing it to bare factoids. The only exception to the pattern lies in its coverage of the movement of the EastAnglian see from Elmham to Thetford, where it retains the source's aspersions about Bishop Herfast's motives: he was afraid, Cronica alleges, of appearing to have done nothing, "because the Normans are most assiduous about their reputation in the future" $(\S 46) .{ }^{107}$

This urge to sanitise sources is in keeping with the general tendencies of John's work. ${ }^{108} \mathrm{He}$ seems to have been a cautious historian, committed above all to the promotion of Marianus Scotus's views about the shape of salvation history. In their eagerness to mine John's version of Marianus's Chronica chronicarum for its information about events in England, modern historians have assumed that its author was animated by the desire to produce another history of the English, similar to those that William of Malmesbury and Henry of Huntingdon were writing at the same time - they have assumed that the Marianan component was merely the "frame" upon which he was attempting to construct a new history of the English. ${ }^{109}$ He certainly provided extended treatment of English events, yet there are many reasons for thinking that Marianus's theories really mattered to him. One reason is the sheer quantity of Marianan material that survives in John's version of the work. Even after four decades spent re-configuring its coverage of the more recent past, Marianus still supplied around half the contents. Another is John's retention of the title Chronica chronicarum, the title which he uses to describe the work in the obituary which he wrote for Florence and in his Chronicula, ${ }^{110}$ because this

\footnotetext{
${ }^{105} \mathrm{WMGP}, 4.156 .1-2$.

${ }^{106}$ Compare WMGP, 4.162, where William says that Pershore was founded and built by another generous lord, Ealdorman Æthelweard Dorset, but "like the rest, it succumbed to so miserable a loss that it was diminished by more than half"; and ibid., 5.198.2, where William criticises the English for their rapacious feasting - a vice that may have caused the extinction of Aldhelm's monasteries at Bradford and Frome; and so on. See Paul Antony Hayward, Power, Rhetoric and Historical Practice: From William of Malmesbury to Geoffrey of Monmouth (forthcoming), chp. 6.

${ }^{107} \mathrm{Cf}$. WMGP, 2.74.11; JWCC $\left(\mathrm{C}^{3} \mathrm{BP}^{3}\right)$, s.a. 1038. The retention of this detail is further evidence that the monks of Worcester had adopted Bury's version of events.

${ }^{108}$ The next two paragraphs summarise positions set out in greater detail in Hayward, Winchcombe and Coventry (n. 26 above), esp. 64-73. Cf. Brett, “John of Worcester” (n. 73 above), 101-26.

${ }^{109}$ E.g. Van Houts, "Historical Writing” (n. 3 above), 112-13. Cf. Chris Given-Wilson, Chronicles: The Writing of History in Medieval England (London, 2004), 158-9; C. M. Kauffmann, Romanesque Manuscripts, 1066-1190, A Survey of Manuscripts Illuminated in the British Isles 3 (London, 1975), 87.

${ }^{110}$ JWCC, s.a. 1118 (3:142); for its use in JWChronicula, see n. 44 above.
} 
was Marianus's own name for the chronicle. ${ }^{111}$ But perhaps the most telling reason for taking John's interest in Marianus seriously is that provided by a twelfth-century reader of his work, Gervase of Canterbury.

Among the chroniclers with whom Gervase finds fault in the prologue to his Chronica are those who have devoted their efforts to revising "the years of the Lord" — to finding an improved chronology for the Sixth Age. It is better, he says, to stick to the Dionysian system even though it is flawed, because these chronicles have only succeeded in proliferating diverse chronologies and causing "dissent" and "much confusion of lies" in the church. In particular he criticises chroniclers who use multiple dating schemes - that is, chroniclers who correlate their annals with two or more alternative calculations of the anni Domini. John of Worcester was certainly guilty of this practice, and it seems certain that Gervase had his work in mind, because he goes on to discuss a Cronica Mariani "assembled from various authorities yet still made known under the name of the same Marianus" that had covered the period from the beginning of the world up to the death of Henry I and Stephen's reign. ${ }^{112}$ Since Gervase, a chronicler who was writing within sixty years of John's time, considered his work a genuine attempt to disseminate a particular chronology and since he also testifies that it caused no little controversy for precisely this reason, it seems best to regard it as an attempt to win converts for the theories of Marianus Scotus.

To be sure, Orderic Vitalis demeaned John's project by characterising it as an attempt to “insert" into Marianus's compendious and useful narrative "the deeds of around one hundred years"; ${ }^{113}$ but there was, perhaps, a well-conceived strategy behind his efforts to enlarge and Anglicise his precursor's coverage of the past. By attempting to assemble a complete history of the English from the potted remnants provided by previous writers and by inserting the results into the annals of Marianus's third book, John will have helped to make his chronology tangible and interesting for local readers. ${ }^{114} \mathrm{He}$ will have made an arcane book more attractive to the English while saving them from having to figure out how the events of their history fitted into the new dating system. It is

\footnotetext{
${ }^{111}$ Marianus calls it the "chronicle of chronicles" because its topic is the greatest of all topics, namely, the true date resurrection of the King of Kings as set out in the Gospels: see Nero C.V, fol. 2v.

${ }^{112}$ Gervase of Canterbury, Chronica, prol., ed. William Stubbs, The Historical Works of Gervase of Canterbury, RS 73, 2 vols. (1879-80), 1:91-594, at 88-89. As the present author has explained elsewhere, Gervase seems to have been attempting to protect his work from conservative critics who were scandalised, not just by these chronological experiments, but by monks wasting time reading and writing history.

${ }^{113}$ Orderic Vitalis, Historia Ecclesiastica, ed. Marjorie Chibnall, OMT, 6 vols. (1968-80), 2:186-8: “...quem [Marianum] prosecutus Iohannes acta fere centum annorum contexuit, iussuque uenerabilis Wlfstani pontificis et monachi supradictis cronicis inseruit, in quibus multa de Romanis et Francis et Alemannis aliisque gentibus quæ agnouit utiliter et compendiose narratione digna reserauit."

${ }^{114}$ Cf. WMGR, 1.pref.1-4.
} 
measure of his devotion to this project that he kept plugging away at it for at least three decades indeed, for well over four decades if the claim, reported by Orderic, that the project was begun on the orders of Bishop Wulfstan II is true. ${ }^{115}$

It is, more to the point, in keeping with this aim of winning converts for Marianus's cause that John renders the rhetoric of his sources harmless. Being offensive would have turned many readers against the message. Thus, the products of John's historical workshop are relatively tame histories. The closest they come to being overtly political is in their complaints about William Rufus's failure to honour his promises to the English ${ }^{116}$ and in their celebration of the achievements of Wulfstan II. ${ }^{117}$ Cronica de Anglia is no exception to the pattern. Its contents are innocuous. It lends a little support to Bury St Edmunds' pretensions to an exemption from the jurisdiction of its diocesan ( $\S 46,62)$, but its only conspicuous bias is its admiration for St Wulfstan. It covers his career with no less than three sections, including one that recounts at length the events of 1088, when he led the defence of Worcester against the rebel army assembled by the barons Bernard of Neufmarché, Roger de Lacy, Ralph de Mortimer and Roger de Montgomery: "a man lovable to God and men, faithful in everything to the king as his earthly lord", Wulfstan "prepared himself manfully that he might stand firm for the people and his city"; "he exhorted his men frequently lest they should lose faith in God"; after he cursed them with an anathema, the invaders "wandering through the fields as if insane, were stuck with such weakness of the limbs, with such blindness of their eyes, that they could hardly carry their weapons, that they could hardly recognise their comrades, that they could hardly make out those opposing them"; "indeed, with the king's and the bishop's soldier shaking his spear, with the prelate raising his hands to the heavens like Moses, the foot soldiers died, the knights were captured - the English as well as the Welsh along with the Normans"; and so on (§ 69). ${ }^{118}$

There is, however, one way in which Cronica de Anglia differs from the histories that have thus far been attributed to John of Worcester. For its approach to the history of England's episcopal sees and religious houses suggests that its composition was, to some extent, driven by an interest in questions of status and rank. Its core narrative ( $\S 1-74)$ is chiefly concerned, for example, with recording when and by whom England's monasteries and episcopal sees were founded - with their claims to antiquity. By consulting these sections a reader could discover, for example, that a rich man, backed by King Æthelberht, built the church of St Peter known as "Westminster" in the year 615 (§

\footnotetext{
${ }^{115}$ See n. 113 above.

116 JWChronicula (fols. 100v). Cf. Hayward, Winchcombe and Coventry (n. 26 above), 82-83.

${ }^{117}$ E.g. JWCC, s.a. 1062, 1070, 1088, and esp. 1095.

${ }^{118}$ Cf. JWChronicula (fols. 98v-100r); JWCC, s.a. 1088 (3:52-56).
} 
5), that Ine's father Cissa built Abingdon in the year 667 ( 1 16), that Abbess Æthelthryth constructed the monastery at Ely in the year 673 ( $(17)$; that Bishop Erkenwald made the monasteries called Chertsey and Baking in the year 675 (§ 18); that Bishop Sæxwulf, who flourished around 680, was the builder and first abbot of the monastery at Peterborough ( $(20)$; and so on. An interest in issues of rank also helps to account for the inclusion of material about the primacy dispute ( $§ 66)$ and the 1075 Council of London - a meeting that determined, as the entry records, the seating order for bishops of the English church at councils and synods (§ 67). Having covered the period from AD 162 to 1125 in this way, the author then embarks on a topographical survey $(\S \S 75-81) .{ }^{119}$ Its subject is quaedam principales cenobia, "certain chief monasteries"; but it is arranged by county and covers only the midlands and western Wessex. It opens, moreover, with an entry that brings issues of status to the fore:

In the province of Somerset the abbey of Bath from ancient times is [now the seat of] the bishopric. There are abbeys there also: Glastonbury is older than the other English abbeys. Not a few bodies of the saints rest there, among whom are the Blessed Patrick, the apostle of Ireland; the confessors his disciple St Benignus, St Aidan also, and St Ceolfrith the abbot; the martyr St Indract with his companions the nine martyrs; the virgins St Hild and St Ælfgyva; and many others. Also in the same province of Somerset are the abbeys of Muchelney and Athelney, and a monastery at Montecute, where are kept a gathering of monks of the Cluniac variety and of decent religion $(\S 75$, emphasis added).

The entry notes Bath's antiquity and Glastonbury's pre-eminence as the oldest abbey in England and as the resting place of numerous saints, including the apostle of Ireland; but it also goes on to note the claims to distinction of a Cluniac Priory that had been founded in the recent past, at the end of the eleventh century by William of Mortain (1090-1106), or perhaps his father Robert (d. 1090). ${ }^{120}$ Similar details occur in the entries that follow: the author notes, for example, that Cerne Abbey was built in a place where Augustine of Canterbury had a vision of God and where St Eadwold had lived on bread and water ( $§ 76)$; Ine’s father, Cissa, appears again as the founder of Abingdon ( $\$ 77)$; St Albans appears as the abbey of the "protomartyr of the English", a detail supplied by the author ( $§$

\footnotetext{
${ }^{119}$ This section is usefully contrasted with genuine topographical surveys, such as Gervase of Canterbury's Mappa mundi, ed. Stubbs, Historical Works of Gervase of Canterbury, 2:414-49, a tabular listing of monastic houses, castles and watercourses, arranged according to the counties of England, Wales, and Scotland in which they were located. See also David Knowles, "Gervase of Canterbury and the Mappa Mundi," Downside Review 48 (1930): 237-47; and for topographical surveys as a common feature of medieval historical writing, see Given-Wilson, Chronicles (n. 109 above), 127-36.

${ }^{120}$ See the synopsis of the foundation charter in Two Cartularies of the Augustinian Priory of Bruton and the Cluniac Priory of Montacute in the County of Somerset, Somerset Record Society 8 (London, 1894), 119-20, along with David Knowles, Christopher N. L. Brooke, and Vera C. M. London (eds), The Heads of Religious Houses, England and Wales, vol. 1, 940-1216 (2nd edn, Cambridge, 2001), 121, n. 1. Montacute was, it should be noted, a largely French institution, whose monks and priors were initially drawn from France rather than the native population: David Knowles, The Monastic Order in England, 940-1216 (2nd edn, Cambridge, 1963), 153.
} 
79); Tewkesbury was "beautifully exalted" by Robert fitz Hamon ( $§ 80)$; and so on. The most striking items, however, are those which record sweeping changes: Reading is noted, for example, as a former nunnery where King Henry had installed monks and to which he had joined "two other houses now decayed, Leominster and Cholsey" ( $§ 77$ ); Oxford features as the site of an ancient monastery, the resting place of St Frideswide, where Roger, bishop of Salisbury (1102-39) had lately installed "canons who would live canonically" (§ 78); and so on.

Cronica de Anglia's topographical survey suggests, then, a readiness to recognise the claims to respect of other monastic houses, but also a sensitivity to the ways in which royal and episcopal sponsorship of new religious movements and other interventions threatened the established order. The chronicle implies that the monks of Worcester Cathedral Priory shared the period's alertness to issues of status and security — one of its great pre-occupations, ${ }^{121}$ but one that is not otherwise prominent in John's works.

There is one more way in which Chronica de Anglia adds to our knowledge of the period. It may not have been compiled at Rievaulx, but its presence among its books helps to illuminate the monastery's textual culture. Though its third abbot, Ailred (1147-67), wrote several fine and highly rhetorical histories and saints' lives, ${ }^{122}$ that culture seems to have been conservative in the extreme. The abbey was not "anti-intellectual" as such, ${ }^{123}$ but it seems to have been far more determined than most to resist cultural activities that diverted monks from the religious life. Aelred wrote about the classics, for example, as a threat to salvation — as sources of "empty" or "harmful" knowledge. There are, he says ${ }^{124}$

many who give their intellect to empty philosophy, for whom it is the custom to meditate on the Bucolica along with the Gospels, Horace with the Prophets, to peruse Cicero with St Paul; then also they give themselves over to playing with metre and to weaving convoluted poems on love, or alternatively to rousing with invectives; wherefore all of these things are condemned by the strictures of the Rule as seeds of vanity, as causes of quarrels and as sources of lust...

It is in keeping with these views that the Rievaulx library catalogue of about $1190 \times 1200$ records a

${ }^{121}$ See Heinrich Fichtenau, Lebensordnungen des 10. Jahrunderts, Monographien zur Geschichte des Mittelalters 30.1 (Stuttgart, 1984), 11-47; trs. Patrick J. Geary, Living in the Tenth Century: Mentalites and Social Orders (Chicago, 1993), $3-29$.

${ }^{122}$ E.g. Aelred of Rievaulx, Vita et miraculis Edwardi regis et confessoris (BHL 2423), ed. Roger Twysden and John Selden, Historice Anglicance Scriptores X, 2 vols. (London, 1652), 1:369-414.

123 Cf. Freeman, Narratives of the New Order (n. 23 above), esp. 91-94.

${ }^{124}$ Aelred of Rievaulx, Liber de speculo caritatis, 2.24, ed. Anselme Hoste and Charles H. Talbot, CCM 1 (1971), 5161, at 100: "Hinc est quod plerique, qui inani philosophiae dedere animum, quibus etiam moris est cum euangeliis bucolica meditari, horatium cum prophetis, cum paulo tullium lectitare, tunc etiam metro ludere laciniosisque carminibus amatoria texere, uel inuectionibus inuicem prouocare, cum eo sese contulerint, ubi haec omnia quasi seminaria uanitatis, uel initia iurgiorum, uel libidinis incentiua regulari districtione damnantur...." 
relatively meagre collection of classical literature, comprising the copy of Dares Phrygius on the Trojan Wars preserved in Royal 6.C.VIII and copies of Seneca's Epistulae morales ad Lucillum and the so-called Liber Catonis - the usual label for a collection of basic texts that often included the fables of Avianus, the Ilias latina and Ecloga of Theodolus as well as the Distichs attributed to Cato the Elder. ${ }^{125}$ The paucity of classical literary texts in this catalogue stands in sharp contrast to its many entries for guides to grammar and rhetoric - a pattern which suggests a determination to teach Latin to a high standard without recourse to pagan texts. ${ }^{126}$ The catalogue shows, moreover, that the abbey possessed a substantial but rather pious set of histories. Besides the contents of the Royal-Vitellius manuscript under discussion and the basic texts that most monasteries sought — that is, the Latin versions of the works of Josephus, Eusebius and Bede - Rievaulx had copies of Aelred's historical works, of Fulcher of Chartres' Historia Hierosolymitana, of Henry of Huntingdon's Historia Anglorum, of the Historia Brittonum, of Palladius's Historia Lausiaca, and of Victor of Vita's Historia persecutionis Africanae prouinciae. ${ }^{127}$ Few monasteries owned so many historical texts at this time, ${ }^{128}$ but the focus is on straightforward works with a strong Christian orientation. There is no sign of Sallust, Lucan or of the most innovative histories that had yet been produced in England, Malmesbury's Gesta regum and Gesta pontificum Anglorum. The presence of Cronica de Anglia, a limited and inoffensive work, is in keeping with this pattern.

It is telling, finally, that just one nota bene occurs in the margins of the relevant folios of Vitellius C.VIII. A neat, twelfth-century, version of the nota monogram — of a kind often found in Cistercian books from northern England - it appears on folio 11v alongside a story about Bishop Byrnstan that celebrates the capacity of liturgical prayer to relieve the souls of the dead. It was his

\footnotetext{
${ }^{125}$ Bell, Libraries of the Cistercians, no. Z19, $\S 83,119 \mathrm{~b}$ and $127 \mathrm{~b}$. For the Liber Catonis and its development in England, see Tony Hunt, Teaching and Learning Latin in Thirteenth-Century England, 3 vols (Woodbridge, 1991), 1:6669 , and the works cited there.

${ }^{126}$ Bell, Libraries of the Cistercians, no. Z19, $\S \S 77-78$ (Isidore's Etymologies, a commentary on Donatus and other guides to the Latin language), 154-5 (Priscian's Institutiones grammaticae), 160 (Pseudo-Cicero's Synonyma, and a guide to versification), 161 (Rethorica in uno uolumine), 163 (Boethius's translation of Porphyry's Isagoge and other tracts on logic), $181 \mathrm{c}+\mathrm{f}+\mathrm{g}$ (Bede's De arte metrica and other grammatical texts). Cf. Birger Munk Olsen, "La diffusion et 1'étude des historiens antiques au XII ${ }^{\mathrm{e}}$ siecle," in Andries Welkenhuysen, Herman Braet, and Werner Verbeke (eds), Mediaeval Antiquity, Medievalia Lovaniensia Series 1 / Studia 24 (Leuven, 1995), 21-43, at 27.

${ }^{127}$ Bell, Libraries of the Cistercians, no. Z19, §§ 43, 54, 55, 104, 112-6, 119a, 136.

${ }^{128}$ The late twelfth-century library catalogue from Whitby, a Benedictine community refounded in 1078, seems to represent the norm for this period: it records just three historical MSS among its eighty-six items, namely, the standards Eusebius, Josephus and Bede: see Richard Sharpe, James P. Carley, Rodney M. Thomson, and Andrew G. Watson (eds), English Benedictine Libraries, the Shorter Catalogues, Corpus of British Medieval Library Catalogues 4 (London, 1995), no. B109 $(\S \S 8,17,18)$. For the general direction of travel, see Teresa Webber, "Monastic and Cathedral Book Collection in the Late Eleventh and Twelfth Centuries," in Elisabeth Leedham-Green and Teresa Webber (eds), The Cambridge History of Libraries in Britain and Ireland (Cambridge, 2006), 1:109-25 (esp. 111-6); eadem, Scribes and Scholars at Salisbury Cathedral, c.1075-c.1125 (Oxford, 1992), 31-43.
} 
usual practice, according to this item, to celebrate a requiem mass each day and to wander around the cemetery by night singing psalms for the dead. On one occasion, "when he added the words 'Let them rest in peace', he suddenly heard voices from the grave as though of a vast army responding 'Amen"” (§ 42). That this item alone was annotated at Rievaulx suggests that the abbey's readers were being directed to material that had a strong eschatological orientation. As many scholars have observed, the historical genres that flourished in Cistercian monasteries were visions of heaven, purgatory and hell and miracula that spoke about the core issues of the religious life. ${ }^{129}$ Other material was to be considered less useful.

\section{CONCLUSION}

The findings of the present study may be summarised as follows. Not a Cistercian but a Benedictine text, Cronica de Anglia was almost certainly produced at Worcester Cathedral Priory between mid 1125 and September 1137, if by not John of Worcester himself, then by members of the team that was labouring under his direction to produce an Anglicised version of Marianus Scotus's Chronica chronicarum. As such it provides more evidence for the magnitude of the priory's contribution to the resurgence of historical writing in early twelfth-century England. Still, it was a history that the Cistercians of Rievaulx thought worthy of inclusion in their library-albeit perhaps only after its chronological apparatus was rendered harmless by the deletion of the Marianan components that the original redaction may have included. Its survival at Rievaulx is probably to be explained by its conservatism. Constructed using excerpts carefully selected from the received tradition, Cronica de Anglia offers a largely uncontroversial history of the English Church. Focused on the relative antiquity and distinction of the kingdom's bishoprics and religious houses, it reveals a sensitivity to the advent of new competitors for religious prestige - to the arrival of the Cluniacs and Augustinians ( $\S 75,78$ and 81$)$; but it is nowhere openly critical of any religious institution.

\footnotetext{
${ }^{129}$ E.g. Christopher J. Holdsworth, "John of Ford and English Cistercian Writing, 1167-1214," Transactions of the Royal Historical Society, 5th ser. 11 (1961): 117-36 (esp. 131-2). See, likewise, idem, "Visions and Visionaries in the Middle Ages," History 48 (1963): 141-53; idem, "Eleven Visions connected with the Cistercian Monastery of Stratford Langthorne", Cîteaux 13 (1962): 185-204 (rpt. with revisions in Richard Sharpe and Robert Easting, Peter of Cornwall's Book of Revelations, Studies and Texts 184 (Toronto, 2013), 216-25); Helen Birkett, "Visions of the Other World from the Cistercian Monastery of Melrose," Mediaeval Studies 74 (2012): 101-41; Giles Constable, "The Vision of Gunthelm and Other Visiones Attributed to Peter the Venerable," Revue Bénédictine 66 (1956): 92-114; Brian Patrick McGuire, "A Lost Clairvaux Exemplum Collection Found: The Liber Visionum et Miraculorum Compiled under Prior John of Clairvaux (1171-79)," Analecta Cisterciensia 39 (1983): 26-62.
} 
The Cronica de Anglia's most striking feature is its compilers' careful suppression of the provocative nuances in the items which they took from William of Malmesbury's Gesta pontificum, a slight exception being made for material that was critical of Bishop Herfast of East Anglia (§ 46). That its compilers lent some support to Bury St Edmunds' efforts to exempt itself from the jurisdiction of the bishops of East Anglia $(\S \S 46,62)$, draws attention to their cursory treatment of Malmesbury. This monastery was also attempting to free itself from the control of its bishop-Roger of Salisbury, who had recently usurped its abbacy; ${ }^{130}$ yet the Cronica avoids saying anything about its status. ${ }^{131}$ A sense of obligation towards St Edmunds - a community that took a direct interest in John of Worcester's project, expressed in its production of Bodley 297, an interpolated but fine copy of his Chronica chronicarum - may explain the Cronica's interest in its history; but having received the first edition of Gesta pontificum, its compilers must also have known of Malmesbury's plight, ${ }^{132}$ and after William had produced his Life of Bishop Wulfstan II their priory's debt to this community would have been just as strong. ${ }^{133}$ Perhaps they wished to avoid commenting on a controversy that had yet to be resolved. Bishop Roger's eminence may also have intimidated them: he was the king's chief minister and a man of immense power. ${ }^{134}$ But whatever the exact explanation, Cronica de Anglia's treatment of William's material helps to show that John and his team, far from being mindless re-cyclers of other people's words, worked to a plan. The arrangement of these items in the Cronica may be somewhat haphazard, but they were selected and edited for a purpose.

\section{Editorial Policies}

In general editorial interventions have been confined to those places where lapses in the sense or

\footnotetext{
${ }^{130}$ Hayward, Power, Rhetoric and Historical Practice (n. 106 above), esp. chp. 2.

${ }^{131}$ Chronica de Anglia, $\S \S 29$ and 77, where it is described as Maldulphi urbs, "Maíldub's town", and as a cenobia monachorum. On the practice of naming minster-towns after their founders, a sign that Malmesbury was once an Irish monastic settlement, see Blair, Church in Anglo-Saxon Society (n. 94 above), 190 and 217, n. 145; Sims-Williams, Religion and Literature (n. 95 above), 106-8.

${ }^{132}$ William alluded to the monastery's situation in WMGP, 2.79.3-6; cf. also WMGR, 2.108.2-3, 135.6. But oral reports of Roger's actions would also have reached Worcester.

${ }^{133}$ Vita S. Wulfstani (BHL 8756), ed. and trs. Michael Winterbottom and Rodney M. Thomson, William of Malmesbury: Saints' Lives, OMT (2002), pp. 8-155.

${ }^{134} \mathrm{Cf}$. WMGP, 1.71.1 $\beta$, where William treats Archbishop Ralph's refusal to allow Roger to preside over Henry I's marriage to Adeliza of Louvain as a courageous act of resistance to "a man of the utmost power". See also Edward J. Kealey, Roger of Salisbury, Viceroy of England (Berkeley and Los Angeles, CA, 1972), 26-81; Judith A. Green, The Government of England under Henry I, Cambridge Studies in Medieval Life and Thought, 4th ser. 3 (Cambridge, 1986), 38-50.
} 
physical damage to the manuscript have made repairs unavoidable. Except at the head of $\S 87$ where the heading has had to be reconstructed, the rubrics are those found in the surviving copy. The present editor has supplied the section numbers. The orthography of personal and place names is quite irregular, suggesting that the scribe had limited knowledge of written English. Since the names are of little value for identifying connections with other texts, the plotting of verbal echoes largely ignores variations in name-forms, except in a few instances where they seem significant. The commentary in the notes is primarily concerned with identifying verbal parallels and with indicating their relative strength: in general, the first item listed in the note indicates the strongest echo, while secondary or weaker echoes follow the abbreviation "cf." (confer). As set out in the list of signs and abbreviations italics and contrasting fonts have used to signal the presence of verbal parallels, the scheme having been worked out so as to accommodate "overlapping" parallels — that is, places where the text is related to more than one analogue.

\section{SigNS AND ABBREVIATIONS}

\section{Sigla}

$\mathrm{V}$

$\mathrm{B}$

$\mathrm{C}$

$\mathrm{L}$

$\mathrm{P}$

BL Cotton MS Vitellius C.VIII, fols. 6v-21v

Oxford, Bodleian Library, MS Bodley 297

Oxford, Corpus Christi College, MS 157

$\mathrm{C}^{3} \quad$ The sections of $\mathrm{C}$ written by the third scribe, i.e. John of Worcester

London, Lambeth Palace Library, MS 42

Cambridge, Corpus Christi College, MS 92, fols. 1r-167v

$\mathrm{P}^{3} \quad$ The sections of $\mathrm{P}$ written by its third scribe.

\section{Palaeographical Data}

$\begin{array}{ll}\text { SMALl CAPITAls } & \text { Rubricated words. } \\ \mid \text { text/ } & \text { Interlinear additions, inserted above line. } \\ \mid & \text { A column change. } \\ <\text { text }> & \text { Text supplied to complete the sense. }\end{array}$

\section{Source-Critical Font Variations}

Italics

Words that echo components of the Chronica chronicarum (JWCC). 
Candara Words that echo JWChronicula.

Courier Words that echo WMGP.

Single underline Words that echo some other source.

John of Worcester

JWCC

The main body of John of Worcester's Chronica chronicarum (i.e. C, pp. 77c396); the annals for AD 450 to 1140 are printed in vols. 2 and 3 of the

Chronicle of John of Worcester, ed. Darlington, McGurk and Bray.

JWBishops John's Episcopal Tables (C, pp. 39-46).

JWKings John's Summary Histories (C, pp. 47-54); the genealogies and histories are printed in Florentii Chronicon ex Chronicis, ed. Thorpe, 1:258-76.

JWChronicula John's Chronicula as found in Dublin, Trinity College, MS 503, fols. 37r$113 \mathrm{v}$.

\section{Other Abbreviations}

$B H L$

Bibliotheca Hagiographica Latina, Antiquae et Mediae Aetatis, Subsidia Hagiographica 6, 2 vols. (Brussels, 1898-99), with Henryk Fros (ed.), Novum Supplementum, Subsidia Hagiographica 70 (Brussels, 1986).

Liebermann, ANG Felix Liebermann (ed.), Ungedruckte anglo-normannische Geschichtsquellen (Strassburg, 1879).

OMT

Oxford Medieval Texts (Oxford, 1950-).

RS

Rolls Series: Rerum Britannicarum Medii Ævi Scriptores, or Chronicles and Memorials of Great Britain and Ireland during the Middle Ages (London, $1858-)$.

$\mathrm{S}$

Peter H. Sawyer, Anglo-Saxon Charters: An Annotated List and Bibliography, Royal Historical Society Guides and Handbooks 8 (London, 1968).

WMGP William of Malmesbury, Gesta pontificum Anglorum, ed. and trs. Rodney M. Thomson and Michael Winterbottom, OMT, 2 vols. (2007).

WMGR William of Malmesbury, Gesta regum Anglorum, ed. and trs. R. A. B. Mynors, Rodney M. Thomson and Michael Winterbottom, 2 vols., OMT (1998-9). 


\section{[fol. 6v, col. a]}

INCIPIUNT QUEDAM CRONICA DE ANGLIA. QUANDO BRITANNI, QUI PRIMUM BRITANNIAM INCOLEBANT, FIDEM CHRISTI SUSCEPERUNT ET QUAMDIU TENUERUNT, DE ADVENTU ET FIDE ANGLORUM, DE CONSTITUTIONE EPISCOPATUUM, ET CONSTRUCTIONE ABBACIARUM, DE MUTATIONE EPISCOPORUM ET ABBATUM ET SEDIUM IPSORUM, DE QUIBUSDAM REGIBUS ET REGNIS ANGLORUM. |

1. De fide Britonum. Anno dominice incarnationis $. \mathrm{c}^{\mathrm{o}} \cdot \mathrm{x}^{\mathrm{o}} . \mathrm{ii}^{\mathrm{o}}$. Eleutherius papa undecimus in ordine post Petrum, sedit annis quindecim, mense uno. A quo Lucius Britannorum rex per epistolam christianum se fieri impetrauit. Susceptamque fidem Britanni .c. et xvi. annis, id est usque in tempora Diocletiani principis inuiolatam integramque quieta pace seruabant. ${ }^{135}$

2. De AdVEntu Anglorum. Ab anno dominice incarnationis. $\mathrm{cc}^{\mathrm{o}} \cdot \mathrm{xxx}^{\mathrm{o}} \cdot \mathrm{ix} \mathrm{x}^{\mathrm{o}}$. quo Dioclecianus regnare cępit usque in annum .cccc.xl.ix. incarnationis, centum .lxx.iii ${ }^{\text {bus }}$. annis expletis, Angli Saxones tribus longis nauibus Britanniam aduecti sunt. ${ }^{136}$

3. De Augustino. Ab anno dominicę incarnatus . $\operatorname{cccc}^{\circ}$.xl.ix. quo Angli in Britanniam uenerunt, usque in annum .d.xc.vii. incarnationis .c.xl.vii. annis expletis, sanctus Augustinus a beato papa Gregorio missus Angliam uenit. ${ }^{137} \mathrm{Ab}$ inicio ergo christianitatis quam Britanni primum habebant, usque ad christianitatem quam per sanctum Augustinum beatus Gregorius Angliam miserat, numerantur anni .ccc $^{\mathrm{ti}} \cdot \mathrm{xl}$.ix. Sed christianitas Britonum .c.xvi. annis durauit. Anglorum uero ex quo cępit, ipsius auctoris gratia per secula durabit. ${ }^{138}$ Anno ab incarnatione Domini .d.xc.vii. sanctus Augustinus a bono Gregorio papa missus, Bri[fol. 7r]tanniam uenit. Et eodem anno baptizato rege Cantuariorum Athelberto, quinto rege a primo rege Hengist nomine, ecclesiam ibi antiquorum Romanorum fidelium opere factam recuperauit, et in nomine Saluatoris sancti sacrauit, ${ }^{139}$ primęque metropolis Anglorum primas et patriarcha ibidem constituitur. ${ }^{140}$ Fecit etiam beatus Augustinus

\footnotetext{
${ }^{135}$ JWCC (C, p. 217), s.a. 162.

${ }^{136}$ Either JWCC, s.a. 450 or JWChronicula (fol. 46r).

137 JWCC, s.a. 596. JWChronicula (fol. 49r), also dates Augustine's departure by reference to the adventus Anglorum, but not by reference to the AD date.

${ }^{138}$ A chronological observation typical of John of Worcester, but none of the established works provides an exact parallel: cf. JWChronicula (fol. 43r).

139 JWCC, s.a. 596, 597, along with information about Æthelberht's place in sequence of Kentish rulers taken from JWKings (C, p. 48). Cf. Bede, HE, 1.33 (p. 114).

${ }^{140}$ The phrase primas et patriarcha appears to derive from WMGP, 1.prol.2: "Ibi prima sedes archiepiscopi habetur, qui et totius Angliae primas et patriarcha." Cf. Goscelin, Historia minor sancti Augustini (BHL 778), ed. PL 105, cols.
} 


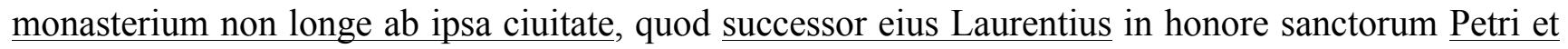

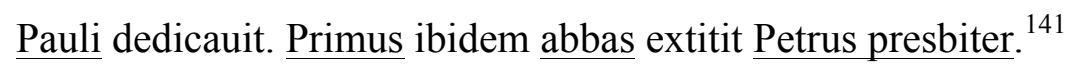

4. De episcopatu Lundoniensis et Rofensi. Anno Domini .dc.iii. sanctus Augustinus Mellitum Romanum abbatem et Iustum ordinauit episcopos. Mellitum ad Lundoniensem constructa iam ibi a rege Athelberto ecclesia sancti Pauli apostoli, Iustum uero ad Rofensem episcopatum. ${ }^{142}$ Ecclesiam in eodem loco rex idem construxit sancto Andree apostolo, cuius honore ipsa sedes ueneratur. ${ }^{143}$

5. De Westmonasterio. Anno Domini .dc.xv., pontificante Mellito, prędiues quidam ciuis Lundonię ciuitatis, commonitione regis Aethelberti construxit ęcclesiam beato Petro in insula, quę primum "Thorneye", id est "Spine Insula", nunc autem, mutato nomine, Latine "Occidentale Monasterium", Anglice uero "Westmenstre" uocatur. ${ }^{144}$

6. De Paulino Eboracensi. Anno Domini .d.c.xx.vi. sanctus Paulinus a beato Gregorio cum cęteris predicandi gratia Angliam missus. Northanhymbranę genti a Iusto Dorobenensi archi|episcopo pontifex ordinatur. ${ }^{145}$ Qui regem Ædwinum cum sua gente baptizauit, habuitque primus sedem episcopatus Eboraci. ${ }^{146}$ Cui Honorus papa palium misit, ipse lpostmodum/ Honorium Iusti successorum in archiepiscopum Cantuariensem in Lindissi prouinc $<$ ia $>^{\text {a }}$ consecrauit. ${ }^{147}$

7. Paulinus Eboracum RelinQuit. Anno Domini .dc.xxxiii. occiso rege Ædwino, turbatisque rebus Northanhymbrorum, Paulinus rediit Cantiam, et honorifice susceptus ab Honorio

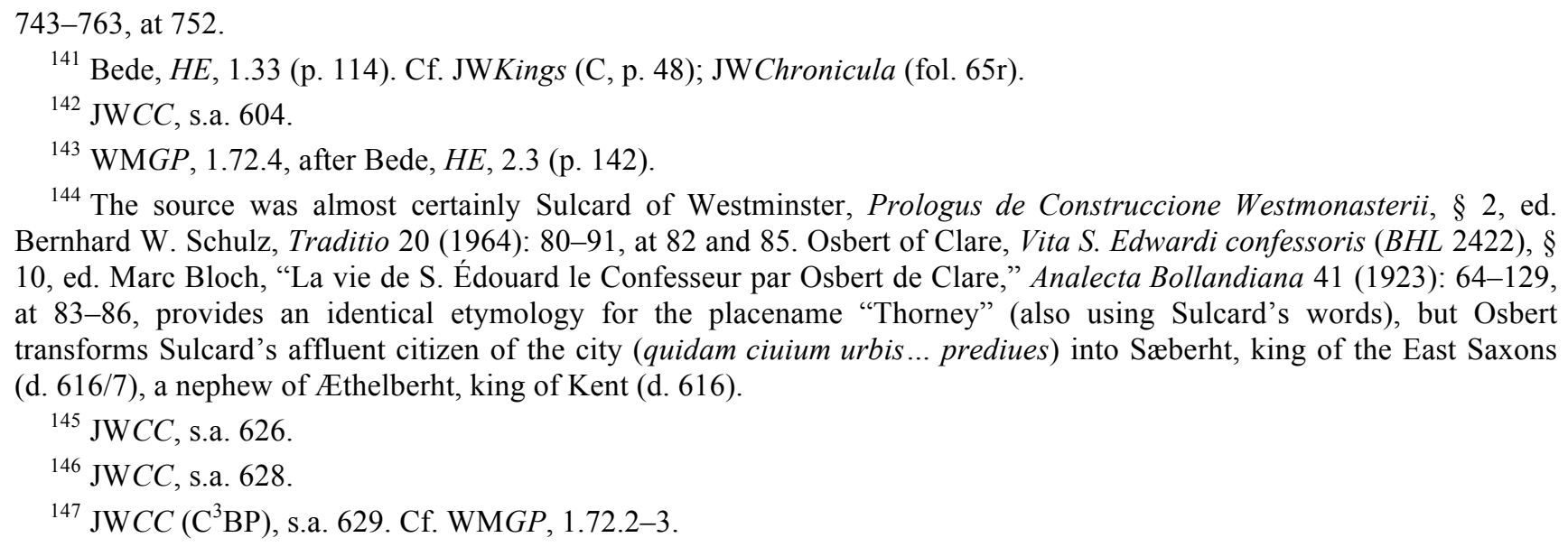

144 The source was almost certainly Sulcard of Westminster, Prologus de Construccione Westmonasterii, § 2, ed. Bernhard W. Schulz, Traditio 20 (1964): 80-91, at 82 and 85. Osbert of Clare, Vita S. Edwardi confessoris (BHL 2422), $\S$ 10, ed. Marc Bloch, "La vie de S. Édouard le Confesseur par Osbert de Clare," Analecta Bollandiana 41 (1923): 64-129, at 83-86, provides an identical etymology for the placename "Thorney" (also using Sulcard's words), but Osbert transforms Sulcard's affluent citizen of the city (quidam ciuium urbis... prediues) into Sæberht, king of the East Saxons (d. 616/7), a nephew of Æthelberht, king of Kent (d. 616). 
archiepiscopo, ${ }^{148}$ non multo post mortuo Romano, ${ }^{149}$ Rofensis episcopus tercius efficitur. ${ }^{150}$ Vbi defunctus pallium reliquit, sicque Northanhymbranę gentis pręsulatus .xxx. annis cessauit. Usu uero pallii ex quo Paulinus Eboracum deseruit per .c.xxv. annos Eboracensis ęcclesia caruit. Quod per Egbertum archiepiscopum fratrem Æthelberti regis Northanhymbrorum, ut fertur eidem ęcclesię restituitur. $^{151}$

8. De BIRINo EPISCOPO. Anno Domini .dc.xxxiiii. Sanctus Birinus ab Honorio papa missus Angliam uenit, et Kenwalh regem Westsaxonum ad fidem Christi conuertens baptizauit, ac solus Westsaxoniam pontificali iure rexit, habens sedem episcopalem in ciuitate Dorich, id est Dorchestre. $^{152}$

9. De Aidano et Lindisfarne. Anno domini .dc.xxxv. Sanctus Aidanus a scottis ordinatus ac missus prouincię rex Oswaldus, uerbum Dei predicans, fundata ibidem ęcclesia, [fol. 7v] gentem illam ad fidem Christi conuertit, primusque factus est Lindisfarnensis episcopus. ${ }^{153}$ Lindisfarne dicitur insula, quae a uulgo "Haligeoland" dicitur. In mari sita est, marisque recessus cotidie siccum iter prebet. $^{154}$

10. DE DEIRA ET BERNICIA. $\leq \mathrm{G}>\mathrm{ens}^{\mathrm{b}}$ Northanhymbrorum in duas prouincias antiquitus diuisa erat. ${ }^{155}$ In una fuit regnum Deirorum, in altera regnum Berniciorum. Quę duo regna coniungit fluuium quod Tyne nominatur. ${ }^{156}$

11. De episcopatu Estanglorum. Anno Domini .dc.xxx.vi. Felix genere Burgundus qui Sigeberto Orientalium Anglorum regi, in Gallia exulanti, familiaris effectus, Angliam eodem cum

\footnotetext{
${ }^{148}$ JWCC, s.a. 633.

149 JWCC (C BP), s.a. 633. Cf. WMGP, 1.72.4-5.

150 JWBishops (C, p. 45).

${ }^{151}$ Comments about the durations of dominions are typical of JW's work, but there is no information to this effect in the prelims or the main body of JWCC, and the calculations do not match the data provided there. JWCC places the elevation of Ecgberht, brother of King Ethelbert to archiepiscopal status (archiepiscopatus insigni sullimatur) under the year 744, a decade after the death of Wilfrid II. But the absence of an archiepiscopus at York is also noted among the marginal additions: JWCC $\left(\mathrm{C}^{3} \mathrm{BP}\right)$, s.a. 653, following $\mathrm{WMGP}, 1.72 .6$.

152 JWBishops (C, p. 41), rather than JWCC, s.a. 635, though in both Birinus converts King Cynegils, not Kenwalh.

153 JWBishops (C, p. 45). Cf. Bede, HE, 3.3 (pp. 218-20); JWCC, s.a. 635.

154 JWCC, s.a. 995.

155 Bede, $H E, 3.1$ (p. 212).

${ }^{156}$ See section three of the introduction above.
} 
uenit, et primus Astanglorum episcopus efficitur, habens sedem episcopalem in ciuitate Dunewich, et eidem genti .xvi. annis prefuit. ${ }^{157}$

12. De eCClesia Wintoniensi. Anno Domini .dc.xliii. Kenwalch rex Westsaxonum apud Orientales Saxones a Felice pontifice baptizatus, ęcclesiam Wintonię in honore sancti Petri construxit, in qua postmodum sedes episcopalis constituta est. ${ }^{158}$

13. De tRIBUS EPISCOPATIBUS. Anno Domini dd.lvi. rex Northanhymbrorum Oswius pro collata sibi a Deo uictoria gentem Merciorum ad fidem Christi conuertit, constituto episcopo Diuma in prouincia Merciorum Lindisfarorum ac Mediterraneorum Anglorum. ${ }^{159}$

14. Westsaxonia in duOs episcopatus Dividitur. | Anno Domini de.lx. Kenwalch rex Occidentalium Saxonum. Westsaxoniam prouinciam in duas parrochias diuisit, et episcopo Wine in ciuitate Wente episcopatus sedem tribuit. ${ }^{160}$

15. De REPARATIONE ARCHIEPISCOPATUS EBORACENSIS. Anno Domini .dc.lxiiii. cessati ${ }^{\mathrm{c}}$ episcopatus Northanhymbrię prouincię anno .xxx $x^{\circ}$. Wylfridus abbas Hripensis monasterii, cuius fundator extitit Ætha abbas cenobii quod uocatur Mailros, cum essent circiter annorum .xxx. in episcopum Eboraci eligitur, et ab Æilberto Parisiace ciuitatis episcopo ordinandus Galliam mittitur. Quo ibi demorante, sanctus Ceadda abbas quondam monasterii quod Glastinghai dicitur. Post uero tercius Merciorum episcopus a Wine ciuitatis Wentanę pręsule, Eboraci ęcclesię pręsul consecratur. Qui tribus annis ęclesiam sullimiter regens, ad monasterii Glastinghai curam secessit. Wilfrido iam reuerso, et accipiente episcopatum totius Northanhymbrorum prouincie.. ${ }^{161}$

16. De AbBandonia. Anno Domini .dc.lxvii. Cissa pater Ynę, regis postmodum Westsaxonum, Abbandoniam construxit. ${ }^{162}$

\footnotetext{
157 JWCC, s.a. 636, except that JW has seventeen years instead of sixteen.

158 JWCC, s.a. 642, 646; but with some echoes of JWChronicula (fol. 50v). Cf. JWBishops (C, p. 41); JWKings (C, p. 53).

159 JWCC, s.a. 655.

160 JWCC, s.a. 660.

161 JWCC, s.a. 664 and 667, but with much re-organisation; cf. JWBishops (C, p. 45).

162 JWCC $\left(\mathrm{C}^{3} \mathrm{BP}\right)$, s.a. 1043. The Abingdon copy $(\mathrm{L})$ has a similar interpolation, but one that also attributes the foundation to King Cædwalla and which appears under the year 688; cf. also WMGP, 2.88.1.
} 
17. De Ely. Anno Domini .dc.lxxiii. in regione quę uocatur Eli, beata Atheldrida, Annę regis Orientalium Anglorum filia, construxit monasterium in quo ipsa prima abbatissa facta est. ${ }^{163}$ Ely, stagnensium insularum [fol. 8r] maxima, ab anguillarum copia ita dicta, ibi ut dictum est Sancta Etheldrida iure abbatissę ancillis Domini pręfuit. Cui successit Sexburg soror eius, uxor Erkenberti regis Cantuariorum, et matris sancte uirginis Erkengote, illique successit altera filia eius Ermenhilda, uxor Wlfheri regis Merciorum et mater Wereburge uirginis. He tres ibidem abbatisse fuerunt, usque ad tempora Danorum, qui habitatricibus effugatis, habitacula subruerunt, sed post ibi canonici constituti sunt. $^{164}$

18. De Certeseia et Berkinga. Anno Domini .dc.lxxv. sanctus Erkenwaldus qui tercius Lundoniensis extitit episcopus, fecit duo monasteria, unum sibi, alterum sorori Æthelburgę. Suum Certeseie dicitur, quod amminiculo Frethewaldi subreguli, opulentia rerum et monachis instituit. Sororis uero monasterium appellatur Berkingum, ubi ipsa prima abbatissa facta est. ${ }^{165}$

19. De Secunda EXPUlsione Wilfridi. Anno Domini .dc.lxxvii. id est anno decimo sui episcopatus, Wilfridus a pręsulatu pulsus est, et pro eo Bosa monachus reuerendus de monasterio Hilde abbatisse in ciuitate Eboraci. Eatha uero uenerabilis ab|b/as Mailrosensis cenobii in Haugustaldensi siue in Lindisfarnensi ecclesia constituuntur episcopi. Cum quibus AEdredus in prouincia Lindisfarorum a Theo|doro archiepiscopo ordinatur episcopus. ${ }^{166}$ Post tres annos abscessionis Wilfridi, ecclesiam Haugustaldensem, remanente Eatha ad Lindisfarnensem, Trumwine ad terram Pictorum in loco qui Candida Casa dicitur, Theodorus archiepiscopus ordinauit. Edredrum uero de Lindissi reuersum, Hripensi ecclesie prefecit. ${ }^{167}$ Pulsus ab episcopatu Wilfridus, Romanque iturus, ubi nauem conscendit, Fresiam pulsus est, ubi multa milia barbarorum ad fidem Christi

\footnotetext{
${ }^{163}$ JWCC, s.a. 673.

164 JWCC $\left(\mathrm{C}^{3} \mathrm{~B}\right)$, s.a. 1111. Cf. WMGP, 4.183.1-5.

${ }^{165} \mathrm{JWCC}$, s.a. 675. WMGP, 2.73.10-13, is almost identical owing to their shared dependence on Bede, HE, 4.6 (p. $354)$, but its words are slightly more remote and it could not have supplied the date.

166 JWCC, s.a. 677.

${ }^{167}$ JWCC, s.a. 681. Trumwine is identified as the first bishop of Candida Casa-a see located in the land of the Pictsin JW's table of northern bishops (C, p. 45).
} 
conuertit. ${ }^{168}$ Relicta Faresia, Romam adiit, auctoritate Benedicti papę Britanniam rediit, ad prouinciam australium Saxonum diuertit, ${ }^{169}$ ubi quinque annis degens in loco qui uocatur Sælesey, quod dicitur Latine insula uituli marini, primus episcopus factus, gentem illam Christo credere fecit. $^{170}$

20. Merciorum PROVINCIA IN CINQUE EPISCOPATUS DIUITUR. Anno Domini .dc.lxxx. Merciorum prouincia cui pontificali iure pręfuit Sexulfus, annis quatuor transactis accepti episcopatus, qui quondam erat constructor et abbas monasterii quod Medeshamstede lid est Burc/ ${ }^{\mathrm{d}}$ dicitur, ${ }^{171}$ in quinque parrochias diuisa est. Et quia ciuitas Wigorna tempore, quo reg|n/abant Britones uel Romani in Britannia, totius Wiccię uel Masscegetanię metropolis extitit famosa, cathedram erexit pontificalem in ea digniter. parrochiarum iam diuersarum primam con[fol. 8v]stituens Wictiam. Ad quam de monasterio Hilde abbatissę uir strenuissimus ac doctissimus Tatfridus electus est antistes. Sed priusquam ordinari posset, morte pręreptus est immatura. Pro quo uenerabilis uir Bosel a Theodoro archiepiscopo ad Wictiam ordinatur episcopus, habens episcopalem sedem in ciuitate Wigorna, que tunc temporis altis muris et menibus pulchris decorata, multis Anglorum urbibus clarior atque sullimior extitit. Secundam diocesim Beatus Theodorus constituit illam que pertinet ad episcopatum Lichesfedensem, cui uirum religiosum ac modestum Cuthwinum pręfecit. Terciam uero Mediterraneam Angliam in qua predictus episcopus Sexulphus quia ita sibi placuit resedit, pontificali cathedra illic constituta in ciuitate Leogria. lid est Lęecestre/ ${ }^{\mathrm{e}}$ Quartam denique Lindissim prouinciam, cui preposuit uirum sanctum Æthelwinum germanum sancti Aldwini abbatis monasterii quod Partaneu[m] lid est Bardenai $/{ }^{\mathrm{f}}$ nuncupatur, statuens ei sedem episcopalem in ciuitate que uocabatur Siddenea. Quintam uero constituit Suthangliam, ad quam de pręfato monasterio Hildę abbatissę singularis meriti ac sanctitatis uirum Ethlam elegit antistitem, eique presulatus sedem in loco qui Dorcacestre uocatur constituit. ${ }^{172}$

\footnotetext{
168 JWCC, s.a. 677.

169 JWCC, s.a. 678.

${ }^{170}$ JWBishops (C, p. 39), but the etymology of the name appears to derive directly from Bede, $H E, 4.13$ (p. 374 ). Cf. WMGP, 2.96.1-4.

${ }^{171}$ JWCC, s.a. 675, makes Sexwulf the constructor et abbas monasterii quod dicitur Burh in regione Giruiorum, but the compiler's use of the name Medeshamstede instead of Peterborough suggests knowledge of JW's source, Bede, HE, 4.6 (p. 354).

${ }^{172}$ This item preserves strong echoes of both JWChronicula (fol. 52rv), and the summary history of Worcester Cathedral and its endowment which appears among the prelims to Chronica chronicarum in C, fol. 1r-p. 3, though both arrange the material in a different order. The parallels to JWCC $\left(\mathrm{C}^{3} \mathrm{BP}\right)$, s.a. 679 , are relatively remote. See section four of
} 
21. De Herefordensi ePISCopatu. | Qui ultra amnem Sabrinam ad occidentem habitant, factus est episcopis Puttha, qui quintus in ordine Hrofensis extiterat episcopus. Hic namque Cantia et Hrosa uastata ab Ethelredo rege Merciorum ad Sexulfum Merciorum episcopum dinertit, et ab eo possessione accepta, ut ferunt quidam primus Herefordensis episcopus extitit. ${ }^{173}$

22. Nomina QUATUOR LOCORUM. Victia dicta est a quodam rege Britonum, qui Wiclh/t nominabatur, ab opaca silva quę Wire dicitur nomen sumpsit. Et qui olim Wictiorum episcopus dicebatur, nunc Wigornensium dicitur, id est Wirecestre. ${ }^{174}$ Lichesfeld est uilla exigua in pago lid est scire/ ${ }^{g}$ Stafordensi, longe a frequentia urbium, nemorosa circa regio. Ibi sanctus Ceadda sedem episcopatus habuit et obiit. Leogrecesta est uilla antiqua in Mediterraneis Anglis, a Leogero fluuio preterfluente sic uocata. Dorcestra est uilla in pago oxenfordensi exilis et infrequens, maiestas tamen ecclesiarum magna, seu ueteri siue opera noua. ${ }^{175}$

23. De Glaorna. Anno Domini .dc.lxxxi. rex Merciorum Ædelredus, ministro suo Osrico qui prouincię Wictiorum tunc prefuit, dedit terram trecentorum tributariorum in urbe Glaorna, ubi constructa et dedicata est ęcclesia in honore sancti Petri.

24. De Persora. Anno Domini .dc.lxxxiii. terram .cce ${ }^{\text {torum }}$. tributariorum idem rex Ædelredus [fol. 9r] concessit alteri ministro suo Oswaldo, prędicti Osrici germano, in Persora, ubi etiam constructa ęcclesia in honore sanctę Marię dedicatur. ${ }^{176}$

the introduction above.

${ }^{173}$ This entry reads like a speculative attempt, based on the occurrence of Putta's name in the episcopal tables for both Rochester and Hereford (C, pp. 39 and 43), to connect the foundation of the latter see with Putta's flight to Mercia-an event reported in Bede, $H E, 4.12$ (p. 368), and elaborated in $\mathrm{WMGP,1.72.7-8.} \mathrm{The} \mathrm{verbal} \mathrm{parallels} \mathrm{point} \mathrm{to} \mathrm{dependence}$ on the re-working of Bede's account in JWCC, s.a. 676. Cf. JWCC (C $\left.{ }^{3} \mathrm{BP}\right)$, s.a. 678, which abbreviates WMGP, 4.163.1.

${ }^{174}$ This item seems to be unique to this source. Cf. JWCC $\left(\mathrm{C}^{3} \mathrm{BP}\right)$, s.a. 679.

175 JWCC (C 3 BP), s.a. 666. Cf. WMGP, 4.172.1, 176, 177.1.

176 The origins of $\S \S 23-24$ are relatively obscure, but they probably rest on a Gloucester source. The material about these abbeys in WMGP, 4.155 and 162, is quite different. Strong parallels occur, however, in the Gloucester foundation narrative which is preserved chiefly in the cartulary-chronicles that were compiled for Walter Frocester, abbot of Gloucester (1382-1412). As H. P. R. Finberg, The Early Charters of the West Midlands, Studies in Early English History 2 (2nd edn, Leicester, 1972), 153-66, showed, this narrative incorporates the remains of an alleged charter of King Æthelred of Mercia (675-704) which recounts how he and his ministers Osric and Oswald founded two churches at Gloucester and Pershore, granting 300 "tributaries" to the former and 300 cassati to the latter. Printed texts appear in ibid., 
25. Episcopatus Orientalium Anglorum diuiditur. Anno Domini .dc.lxxxiiii. Bisy quartus a Felice primo Orientalium Anglorum episcopo pręsul uita discessit. Post quem duo rexerunt pontifices prouinciam illam, usque ad tempora Egberti septimdecimi regis Westsaxonum, quorum unus sedebat apud Dunewich, alter apud Helmatham. Quod .c.xliii. annis, .xxii. episcopis pontificantibus per durauit. Extinctis uero regibus .c.xxxix. annis ibidem pre inopia destituti sunt episcopi, usque ad regis Anglorum Ædwini tempora. ${ }^{177}$

26. De Iohanne Haugustaldensi. Anno Domini .dc.lxxxvi. Eatha Haugustaldensi episcopo defuncto, Iohannes successit. Sed Wilfrido Haugustaldum recepto, et Bosa defuncto, idem Iohannes pro eo Eboraci substituitur. ${ }^{178}$

27. De WiLfrido. Anno Domini .dc.xci. Wilfridus denuo pręsulatu pulsus, ab Adelredo rege Merciorum suscepit episcopatum ${ }^{\mathrm{h}}$ mediterraneorum Anglorum. ${ }^{179}$

28. De Heuesham. Anno Domini .dc.xcii. Sanctus Egwinus tercius in ordine Wictiorum episcoporum monasterium, quod Eouesham dicitur, construxit. ${ }^{180}$

158, and Historia et cartularium monasterii sancti Petri Gloucestriae, ed. William H. Hart, RS 33, 3 vols. (1884-93), 1:lxxi-lxxii. Fragments of this narrative appear in earlier documents: a late twelfth-century scribe inserted, for example, extracts from an earlier version into the margins of the Winchcombe Chronicle (n. 57 above), s.a. 680.2 (2:436), where unfortunately they were much damaged in the Cottonian Fire; minor echoes also appear in the late fourteenth-century Pershore chronicle by Dominus Garterius, whose contents were partly recorded by John Leland, De rebus britannicis collectanea, ed. Thomas Hearne, 6 vols. (2nd edn, London, 1770), 1:240. It seems likely that this narrative and the alleged charters which it contains existed by the early twelfth century-at the very latest. On the authenticity of this charter, see also Anton Scharer, Die angelsächsische Königsurkunde im 7. und 8. Jahrhundert, Veröffentlichungen des Instituts für Österreichische Geschichtsforschung 26 (Vienna, 1982), 146-8. None of the known witnesses preserves, however, any information about the identity of the saint to whom Pershore was dedicated. For this detail a parallel of sorts exists in the material about Gloucester and Pershore that John added to the margins of his autograph (JWCC $\left(C^{3}\right.$ B), s.a. 1095 (3:78, 80)). These items say nothing about how much land was given to Gloucester and Pershore, but they identify the same persons as founders, and the item about Pershore includes a statement to the effect that Oswald built the church at Pershore in honore sancti Petri, but that it is now dedicated in nomine Dei genitricis Marie. One possibility is that the author was combining material from the charter of King Æthelred and Cronica chronicarum and that the information about the dedication of Pershore was corrupted - either by the author himself or at some stage in the transmission of Cronica de Anglia. Another and more likely possibility is that the author was relying on John's working notes and that they differed somewhat from the material now perserved in the margins JWCC $\left(\mathrm{C}^{3} \mathrm{~B}\right)$, s.a. 1095 - that they contained, for example, more data about how much land was given to Pershore and Gloucester than John chose, in the end, to include in Chronica chronicarum.

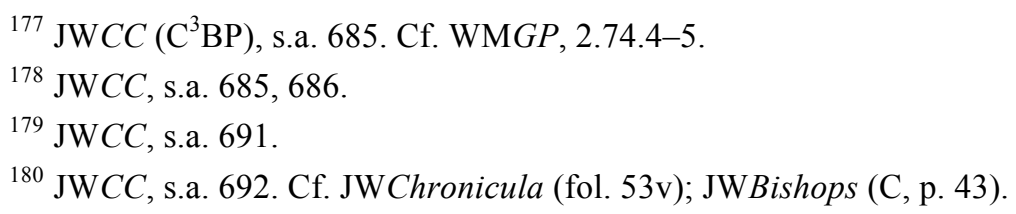


29. Duo episcopatus Diuiduntur. Anno Domini .dcc.v. sancto Headda Wintoniensi episcopo defuncto, episcopatus prouincie illius | in duas parrochias diuisus est, una data Danieli, altera Aldelmo, qui .xl. iam annis abbas extiterat Maldulphi urbis, ambo $<r e>b u s^{\mathrm{i}}$ consecratis a Bertwaldo Dorobernensi octauo archiepiscopo. Sexulphus Merciorum episcopus uita decessit, ${ }^{181}$ postea Merciorum prouincia duos episcopos habuit, Headdam et Wilfridum, Headda apud Lichesfeld, Wilfridus apud Leogrecestre. Sed illo mox ui hostilitatis eiecto, mortuoque rege Northanhymbrorum Alhfrido ad pristinam sedem episcopatus, id est Haugustaldum in concordiam receptus reuertitur, ${ }^{182}$ ibique in pace quatuor annis expletis ut sibi promiserat angelus, in pace uitam finiuit. ${ }^{183}$ Headda uero ambas post rexit parrochias, et post eum Alwinus qui et Wor. ${ }^{184}$

30. De statu episcopatuum tocius Britannię Secundum Bedam. Anno Domini .dcc.xxxi. ab aduentu Anglorum in Britanniam anno circiter ducentesimo octogesimo secundo, ęcclesiis Cantię Tatwinus et Aldwinus episcopi prefuerunt. Porro prouincie Orientalium Saxonum Ingualdus, episcopus, prouincie Orientalium Anglorum Eadbertus et Hadulacus episcopi, prouincię Occidentalium Saxonum Daniel et Fodherus episcopi, prouincię Merciorum Aldwinus episcopus, eis populis qui ulta Sabrinam amnem ad occidentem habitant Walstod episcopus, prouincię Wictiorum Wilfridus episcopus. [fol. 9v] prouincię Lindisfarorum Kynebertus prefuit. Episcopatus Wectę insulę ad Danielem pertinebat episcopum Wente ciuitatis. Prouincia Australium Saxonum iam aliquot annis absque episcopo manens, ministerium sibi episcopale ab Occidentalium Saxonum antistite quesiuit. Hę omnes prouincię, cętereque australes ad confinium Humbre fluminis cum suis queque regibus, Merciorum regi Adelbaldo subiecte fuerunt. At uero prouincie Northanbymbrorum cui rex Ceolwulphus prefuit. quatuor episcopi pressulatum tenuerunt, Wilfridus in Eboracensi ęcclesia Adelwoldus in Lindisfarnensi, Acca in Haugustaldensi, Pectelmus in ea que Candida Casa uocatur. Britones magna ex parte Anglorum seruicio mancipati fuerunt. ${ }^{185}$

31. Item de Statu episcopatuUm. Anno Domini .dcc.xxx.iiii. quo anno sanctus Beda migrauit ad

\footnotetext{
181 JWCC, s.a. 705. The duration of Aldhelm's abbacy could have been inferred from annal in JWCC, s.a. 666, which records his ordination as abbot of Malmesbury.

${ }^{182} \mathrm{JWCC}\left(\mathrm{C}^{3} \mathrm{BP}\right)$, s.a. 705. Cf. WMGP, 3.110.2; 4.172.2.

${ }^{183} \mathrm{WMGP}, 3.109 .6$.

${ }^{184} \mathrm{JWCC}\left(\mathrm{C}^{3} \mathrm{BP}\right)$, s.a. 705. Cf. WMGP, 4.172.2.

185 The rubric shows that the compiler knew that the ultimate source of this item was Bede, HE, 5.23 (pp. 558-60), but the textual affinities imply derivation from JWCC, s.a. 731.
} 
Dominum, defuncto iam Aldwino, qui et Wor, .iii ${ }^{e s}$. facti sunt episcopi in Leogrensi diocesi. Hwita Lichesfeld, Tot $\mid \mathrm{h} / \mathrm{a}$ Leogrecestre, Eatta de quo supradiximus in Dorcacestra remanente. ${ }^{186}$ Huius episcopi solius nomen, qui Dorcacestrensis extitit episcopus reperitur. Presulatus uero sedem post illum in Dorcestra Lindissę pręsules habuerunt .ccc.liiii. annis, quousque Remigius genere Normannus, Lindisfarorum episcopus septimusdeci|mus licentia regis Willelmi senioris sedem pręsulatus mutaret de Dorcacestra ad Lincolniam. ${ }^{187}$ Eodem quoque anno Tatwinus, nonus Dorobernię archiepiscopus, uita decessit, cui Nothelmus Lundoniensis ęcclesię presbyter successit. ${ }^{188}$ Hic Ædbertum, qui abbas monasterii sancti Wilfridi, quod dicitur Scelesey, fuerat, prouincię Australium Saxonum ordinauit episcopum. Qui secundus post Wilfridum Sæleseiensis episcopus extitit. ${ }^{189}$ Pontificalis sedes apud Sælesey usque ad tempora Willelmi regis senioris .ccc.xxxiii. annis, episcopis .xix. pontificantibus, durauit. Postmodum a Stigando Sæleseiensi episcopo .xx ${ }^{\text {mo }}$. mutata est sedes episcopalis de Scelesey ad Cicestram. ${ }^{190}$

32. De Winchelcumbe et Sancto Albano. Anno Domini .d.cc.lxxxvii. rex Merciorum Offa, in Glaornensi pago, in loco qui Winchelcumbe dicitur, monasterium construxit in quo sanctimoniales constituit. ${ }^{191}$ Pagus Bedefordensis continet abbaciam sancti Albani martiris. Cuius corpus sanctissimum quod diu iacuerat in terre puluere, rex offa in scrinio collocauit. Erexit in limine basilicam pulcherrimi operis, monachorum numerositate honorauit. ${ }^{192}$ Anno Domini .dcc.xc.viii. rex Merciorum Kenulfus Winchelcumbense monasterium construxit, et in eo monachos numero .ccc. collocauit. Ecclesia [fol. 10] eiusdem monasterii dedicata est a .xiii. episcopis, quorum princeps erat Wulfredus Cantuarię archiepiscopus. ${ }^{193}$

\footnotetext{
${ }^{186} \mathrm{JWCC}\left(\mathrm{C}^{3} \mathrm{BP}\right)$, s.a. 734. Cf. WMGP, 4.172.2.

187 JWCC, s.a. 1092, together with information about the history of the see from JWBishops (C, p. 43). This table has just one name under Dorchester (Aetla), and Remigius appears as the seventeenth bishop of Lindsey.

188 JWCC, s.a. 734, and JWBishops (C, p. 39).

189 JWBishops (C, p. 39).

190 The author's statements and words agree with the data found in JWBishops (C, p. 39), which makes Stigand the twentieth holder of the see of the South Saxons and the first to reside at Chichester. Cf. JWCC (C BP), s.a. 1070; WMGP, 2.96.4.

${ }^{191}$ See the section five of introduction and esp. n. 93 above.

192 JWCC $\left(\mathrm{C}^{3} \mathrm{~B}\right)$, s.a. 1048, which has Hertfordensi instead of Bedefordensi, but Hertfor- is written over an erasure. Cf. WMGP, 4.179.1, who has in lumen, "to the light", for in limine, "in limestone".

${ }^{193}$ WMGP, 3.156. This item also appears in the margins of the Winchcombe Chronicle (n. 57 above), s.a. 798 (2:452), where it was added s.xii/xiii. This parallel is best interpreted, therefore, as evidence for the reception of the Cronica de Anglia in the diocese of Worcester where it seems to have originiated: see also Hayward, Winchcombe and Coventry (n. 26 above), 1:246, 249 .
} 
33. De Haugustaldensibus episcopis. Post Accam Haugustaldensem episcopum, cuius inter alios sanctos Beda fecit mentionem in fine hystorię Anglorum, septem tamen Haugustaldenses in ordine se sequentes episcopi fuerunt per lxxviii. ferme annos. ${ }^{194}$ Exercitus enim Danorum uehemens, habitatoribus extinctis uel effugatis, habitaculorum tecta succendit, et secreta celo exposuit. Nunc est Hesteldesham uilla presulis Eboracensis. ${ }^{195}$

34. DE CANDIDA CASA. Candida casa uocatur locus in extremis Anglie iuxta Scotiam finibus, ubi beatus Nina confessor requiescit, natione Britannus, qui primus ibidem Christum euangelizauit. Nomen loco ex opere inditum quod ecclesiam ibi ex lapide polito Britonibus miraculo fecerit. Ibi sub extremo Bede tempore, episcopus factus est Pectelmus, qui multo ante tempore in Westsaxonia commoratus, sanctissimi Aldelmi discipulatui interfuerat. Ei subiecti sunt Fredewaldus, Pectwinus, Edebrictus, Beadulphus, Eadredus. Post hunc episcopatus deficit, quia extrema or $\mathrm{a}^{j}$ est Anglorum et Scottorum et Pictorum depopulationi oportuna. ${ }^{196}$

35. Alfredi Regis operA. Anno Domini .dccc.lxxx. rex West|saxonum Alfredus, Sceaftoniam quandam urbem, que modo uicus est, edificauit. ${ }^{197}$ Wintonię quoque monasterium quod uulgo nouum dicitur, construxit, et Grimbaldo quodam Flandrensi suadente, ipse rex Alfredus in eo canonicos posuit. ${ }^{198}$ Anno Domini .dccc.lxxxvii. rex Alfredus duo monasteria construere fecit, unum monachorum in loco qui dicitur Athelingeie, et Iohannem presbyterum |uel monachum/ genere Aldsaxonem, abbatem constituit. Aliud uero monasterium iuxta Orientalem portam Sceaftesberię, habitationi sanctimonialium habilem, idem rex edificari imperauit, in quo propriam

\footnotetext{
194 JWBishops (C, p. 45), has seven bishops of Hexham after Acca. The reference to Bede echoes WMGP, 3.117.3, but WM has six bishops after Acca, omitting Alhmundus.

${ }^{195} \mathrm{JWCC}\left(\mathrm{C}^{3} \mathrm{BP}^{3}\right)$, s.a. 828. Cf. WMGP, 3.117.5.

${ }^{196} \mathrm{JWCC}\left(\mathrm{C}^{3} \mathrm{BP}^{3}\right)$, s.a. 828. JW was here working from WMGP, 3.118.1, 3, but he has added Eadredus (Heathored) to WM's list of bishops, in keeping with JWBishops (C, p. 45).

197 JWCC (C BP), s.a. 880. Cf. WMGP, 2.86.1.

${ }^{198} \mathrm{JWCC}\left(\mathrm{C}^{3} \mathrm{~B}\right)$, s.a. 1070. Cf. WMGP, 2.78.1.
} 
filiam Agelgeouam, deuotam domino uirginem, abbatissam constituit. ${ }^{199}$ Construxit et aliud monasterium Wintonię sanctimonialium, quibus Alfridam uirginem abbatissam preposuit. ${ }^{200}$ Ethelingeie est non maris insula, sed ita stagnis et paludibus inaccessa, ut non nisi nauigio adiri queat. Ceruos et capreas multasque id generis bestias continet. Terra solida, et uix duobus iugeribus lata, monasteriolum et monachorum officinas habet. Eius ut dictum est constructor fuit rex Alfredus, qui quondam a Danis pulsus prouincia, tutas ibi aliquandiu latebras confouerat. Mox cum per somnium restitutionis sue uadem sanctum Cuthbertum [fol. 10v] accepisset, ibidem monasterium se constructurum Deo pollicitus est, quod et postea fecit. ${ }^{201}$

36. Duo episcopatus Westsaxonum In CINQUe DiVIDUnTUR. Anno Domini .dcccc.viii. rex Anglorum Ædwardus cognomento senior, et archiepiscopus Dorobernię Pleimundus, salubri consilio habito, singulis tribubus Gewissorum, id est Westsaxonum, singulos constituentes episcopos, singulis episcopia constituerunt, et quod olim duo habuerunt in quinque diuiserunt. Ipseque Pleimundus in ciuitate Dorobernia .vii. episcopos septem ęcclesiis in una die consecrauit. Frithestanum ad Wintoniensem ÆEdelstanum ad ęcclesiam Coruinensem uel Sunmungensem, nunc uero mutata sede Seresberiensem, Werstanum ad ęcclesiam Scireburnensem, Ędelmum ad Fontanensem, Eadulfum ad Cridiatunensem, Bernetum Australibus Saxonibus, Kenulfum uero Mercis Australibus ad ciuitatem quę dicitur Dorkacestre. ${ }^{202}$

37. De ePISCOPATU SALESBERIENSI. Ethelstanus in Wiltuniensi pago primus factus episcopus sedem pontificalem in Ramesberia habuit. Similiter et successores illius per .ccc.lii. annos, quousque Heremannus nonus Ramesberiensis episcopus, Scireburnensem presulatum mortuo Ælwoldo, a rege Eadwardo adquisitum | ęcclesię suę copulauit, et cathedram episcopalem utrorumque episcopatuum de Ramesberia Scireburne sibi constituerit. Sed rege Willelmo seniore regnante, synodali auctoritate,

\footnotetext{
199 JWCC, s.a. 887.

${ }^{200}$ JWCC $\left(\mathrm{C}^{3} \mathrm{~B}\right)$, s.a. 1070 (italics). Cf. JWCC, s.a. 905, where the construction of the Nunnaminster is attributed, using very similar language, to Alfred's queen, Ealhswith.

${ }^{201} \mathrm{WMGP}, 2.92 .1-2$; JWCC (C $\left.{ }^{3} \mathrm{BP}\right)$, s.a. 882.

${ }^{202}$ Almost identical echoes occur in both JWChronicula (fol. 64r), and among the explanatory matter in JWBishops (C, p. 41), but the present text is slightly closer to the former version. Cf. JWCC, s.a. 909.
} 
ac eiusdem regis munificentia, inde ad Salesbiriam sedem suam mutauit. ${ }^{203}$ Ab anno Domini .dcc.vii., quo sanctus Aldelmus primus Scireburnensem pręsulatum suscepit, usque in annum millesimum .lx.ix., quo Heremannus Ramesberiensis episcopus mutauit, ut diximus, sedem episcopalem Seresberiam, computantur .ccc.1 $\backslash \mathrm{x} / \mathrm{ii}$. anni, pręsulibus .xxiiii. in ordine pontificantibus. ${ }^{204}$

38. De episcopatu De Welles. Ab anno Domini .d.cccc.viii. in quo Ædelmus factus est primus Wellensis episcopus, usque in anno domini .m.xci. numerantur anni .c.lxxxii. pręsulibus interim .xiiii. in ordine pręsulantibus. ${ }^{205}$ Iohannes uero successor Gysę, ${ }^{\mathrm{x}}$ xiiii $^{\mathrm{us}}$ Wellensis episcopus, natione Turonicus, non tam arte quam usu medicus, annuente rege Willelmo iuniore, pręsulatus sedem de Wellis transtulit Bathoniam. ${ }^{206}$ Huius loci fundator ut ab antiquis accepimus, extitit olim quidam Akemannus nomine, unde uulgo Akemannescestre, id est ciuitas Akemanni dicitur. $^{207}$

39. De Cridiatunensi episcopatu. Ab anno Domini .dcccc.viii. in quo Eadulfus factus est primus Cridiatunensis episcopus usque in annum Domini .m.xxxi. computantur anni .c.xxii. episcopis [fol. 11r] interim .viii. ex ordine pontificantibus. Liuingus ex monacho Wintoniensi, post Theauestocensis abbas, eodem anno Domini .m.xxxi. factus est nonus Cridiatunensis episcopus. Hic processu temporis maxime familiaritatis et potentie apud Canutum regum Anglorum habitus, eo apud illum genere processit, ut defuncto aunculo suo Brichwoldo qui erat Cornubiensis episcopus, ambos arbitrio suo uniret episcopatus, factusque est idem Liuingus postmodum

\footnotetext{
${ }^{203}$ Verbal echoes clearly imply that this entry is related to John of Worcester's table of West-Saxon prelates, JWBishops (C, p. 41), but for the purpose of calculating the duration of see, prior to its relocation at Old Sarum, the compiler assumes - rather oddly given the relative clarity of JW's table - that Æthelstan became bishop of Ramsbury at the same time as Aldhelm became bishop of Sherborne when the former see was in fact founded in the reign of Edward the Elder (899-924). The correct span for the presence of an episcopal seat at Ramsbury would be around 167 years.

${ }^{204}$ JWBishops (C, p. 41) makes Aldhelm the first holder of the episcopate of Sherborne and lists 24 bishops as holder of that office; for the dates, cf. JWCC, s.a. 709 and $\left(C^{3}\right.$ BP), s.a. 1070.

${ }^{205}$ This chronological excursus could have been developed by using the date specified in $\S 36$ above and JW's table of West Saxon prelates (C, p. 41). The table lists fourteen bishops of Wells from Æthelhelm to [G]isa, before listing John and $[\mathrm{G}]$ odefridus as the fifteenth and sixteenth. Cf. WMGP, ii.90.1.

${ }^{206} \mathrm{JWCC}\left(\mathrm{C}^{3} \mathrm{BP}^{3}\right)$, s.a. 1091, following WMGP, 2.90.2. In their existing form JW's table of West-Saxon bishops (C, $\mathrm{p}$. 41) lists John as the fifteenth bishop of Wells, but the list shows signs of revision.

${ }^{207}$ This etymology seems to have been inferred from the name itself - a form that the author may have discovered by reading the account of Edgar's coronation at Bath found under the year 973 in several versions of the Anglo-Saxon Chronicle, such as the C-Text (ed. K. O'Brien O'Keeffe, The Anglo-Saxon Chronicle: A Collaborative Edition, vol. 5, MS $C$ (Cambridge, 1983), 82). Cf. C. Plummer and J. Earle (eds), Two of the Saxon Chronicles Parallel, 2 vols. (Oxford, 1892-9), 2:161.
} 
. $\mathrm{xx}^{\text {us }}{ }^{\mathrm{ii}}{ }^{\text {us }}$. Cornubiensis episcopus. De quo ut a maioribus accepimus, cum spiritum efflaret, tam horrisonus crepitus per totam Angliam auditus est, ut ruina et finis totius putaretur orbis. Humatus est Theauestoce. Huic successit Lefricus Brito, apud Lotharingos altus et doctus, qui sedem pręsulatus transtulit in ciuitatem quę propter fluuium Exam qui muros lapsu suo allambit, uocatur Exacestre. Hanc urbem primus rex Edelstanus in potestatem Anglorum effugatis Britonibus redactam, turribus muniuit, muro ex quadratis lapidibus cinxit. Hic Leofricus eiectis sanctimonialibus a sancti Petri monasterio, episcopatum et canonicos statuit, qui contra morem Anglorum ad formam Lotharingorum uno triclinio comederent, uno cubiculo cubitarent. Successit Leofrico Osbernus | regis Willelmi tempore natione Normannus, frater Willelmi precellentissimi comitis in Anglia. Vixit ad quartum annum regis Anglorum Henrici, non paucis annis pre senio lumine captus. Cui successit Willelmus de Wirewast cognatione, oculorum nunc uisu, non tamen senio sed quolibet infortunio, omnino priuatus. ${ }^{208}$ Cridiatun est uilla Dommanie que dicitur Deuenescire, duobus milibus ab Exacestra. ${ }^{209}$ Cornubiensium sane pontificum, ordinem et nomina nec scio nec appono, nisi quod apud sanctum Petrocum fuerit sedes episcopalis. Locus est apud aquilonales Britones supra mare iuxta fluuium Liner supra mare in australi parte. ${ }^{210}$

40. De Glaorna. Anno Domini .dcccc.xx. in urbe Glaorna Ægelfleda Merciorum domina soror Eadwardi regis senioris, ut pater suus rex Alfredus illi preceperat, cum coniuge suo Ethelredo Mercensium duce, monasterium edificauit, illucque de cenobio quod Beardanei dicitur, quod situm est in Lindissi prouincia, reliquias sancti regis Oswaldi transtulerunt. ${ }^{211}$

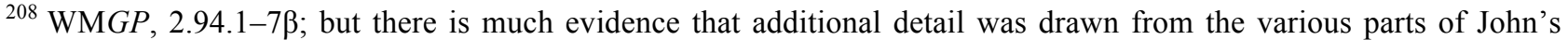
corpus. The dates towards the beginning of the chapter echo, slightly inaccurately, those in JWCC, s.a. 909 ( $\left.\mathrm{C}^{3} \mathrm{BP}\right)$, and 1031; the numbering echoes the data in JWBishops (C, p. 41); and the detail that Leofric was a Briton occurs in JWCC, s.a. 1046.

${ }^{209} \mathrm{JWCC}\left(\mathrm{C}^{3} \mathrm{BP}^{3}\right)$, s.a. 972 , following WMGP, 2.94.1. JW rightly has .xii. milibus.

${ }^{210} \mathrm{WM} G P, 2.95 .7$.

${ }^{211}$ WMGP, 4.155. Note how "in the time of King Alfred" becomes "as her father King Alfred had ordered her". Cf. JWCC, s.a. 910; JWChronicula (fol. 63v); JWCC (C ${ }^{3}$ B), s.a. 1050.
} 
41. De Odone Wiltuniensi EPIScopo. Anno Domini .dcccc.xx. defuncto Adelstano primo Wiltuniensi episcopo, successit Odo. Hic Danice gentis oriundus fuit, cuius parentes regis Alfredi tempore [fol. 11v] Angliam infestauerunt, sed illis abeuntibus uel extinctis, Edwardo regi militans aliquandiu, non multo post comam tonsus, clericatum professus est, meritisque crescentibus, Wiltuniensi ecclesie prelatus, Ethelstanum regis Adwardi filium, in sui amiciam excitauit. $^{212}$

42. De Brinstano EPISCOPO. Anno Domini .dcccc.xxxii. sancto Frithestano Wintoniensi episcopo $<$ defuncto>, successit Brinstanus. Hic uir sanctus cotidie missam pro defunctorum requie celebrare consueuerat, nocte cimiteria circuire, prodefunctis psalmos cantare. Quadam uice hoc agens, dum expletis omnibus subiungeret, "requiescant in pace", subito uoces quasi exercitus infiniti e sepulcris audiuit respondentium "Amen". ${ }^{213}$

43. Odo FIT ARCHIEPISCOPUS. Anno Domini deccc.xxxiii. Wulfelmo Dorobernie archiepiscopo defuncto, Odo episcopus in primatum Cantie eligitur. Sed ille ut qui nondum amicisset monachum constantius reniti, ne morem maiorum ambitione sua turbare uideretur. Nullus enim eatenus, non monachus, archiepiscopus ibidem extiterat. Sed cum regie uoluntati, episcoporum omnium assensus accederet, tandem uir reuerentissimus propositi sui rigore edomito, transito mari apud Floriacum monachilia accepit, et in Angliam rediens, in Cantuari|ensem archiepiscopum leuatus, magnamque apud Adelstantum, et non imparis amicicie apud Edmundum, gratiam tenuit. ${ }^{214}$ Odoni successit in episcopatum Wiltuniensem Osulphus. ${ }^{215}$

\footnotetext{
${ }^{212} \mathrm{JWCC}\left(\mathrm{C}^{3} \mathrm{BP}\right)$, s.a. 920. Cf. WMGP, 1.14.

${ }^{213}$ JWCC, s.a. 932. Cf. WMGP, 2.75.24. A near-contemporary hand enters a nota symbol in the margin beside this item, providing one of the few signs that the text was the subject of study.

${ }^{214} \mathrm{JWCC}\left(\mathrm{C}^{3} \mathrm{BP}^{3}\right)$, s.a. 934. Cf. WMGP, 1.14.4-15.1.

${ }^{215} \mathrm{JWCC}\left(\mathrm{C}^{3} \mathrm{BP}^{3}\right)$, s.a. 934. The compiler has rightly corrected JW's Wellensium, inserting Wiltuniensem in its place. Cf. WMGP, 2.83.1.
} 
44. Mideltune et Michielnei Construuntur. Anno Domini .dcccc.xxxiiii. rex Anglorum Ethelstanus Mideltunensem ecclesiam fecit pro anima fratris sui Edwii, quem prauo corruptus consilio Anglia eiecit. Eadem causa Miclaneiense cenobium construxit, quod situm est in Sumerseta. ${ }^{216}$

45. De Sceaftuna. Anno Domini deccc.xliiii. Eluiua regina regis Eadmundi, qui fuit pronepos regis Alfredi, construxit monasterium sanctimonialium Scęftunię. ${ }^{217}$

46. Duo episcopatus IUnguntur. Anno Domini .dcccc.lvii. regnante Eadwino, episcopatum Orientalium Anglorum quem .c.lxxiii ${ }^{\text {bus }}$. annis, duo rexerant pontifices, unus regere cepit, cui nomen Adulfus, habens episcopalem sedem in Elmaham, eodemque modo eius successores. Quę sedes episcopalis .c.xiii. annis ibidem habita est, usque in annum quintum regis Anglorum Willelmi senioris, id est usque in annum Domini .m.lxxi. ${ }^{218}$ Quo anno Arfestus .xx ${ }^{\text {usiii }}{ }^{\text {us }}$. Æstanglorum episcopus, ne nichil fecisse uideretur, ut sunt Normanni fame in futurum studiosissimi, licentia regis eiusdem sedem pręsulatus de Elmaham transtulit in Theot[fol. 12r]fordam. ${ }^{219}$ At successor eius Herebertus sedem episcopalem transportauit ad insignem mercimoniis uicum nomine Norwich. ${ }^{220}$

47. DUO EPISCOPATUS IUNGUNTUR LEGRECESTRIĘ ET LiNCOLNIĘ. Anno Domini .dcccc.lix. Ædgarus germanus regis Ædwii, anno ętatis sue .xvi. regnare cępit. ${ }^{221}$ Quo regnante Leowinus octauus Legrecestrensis episcopus, licentia illius duos episcopatus, Lindis qui nunc dicitur Lincolliensium, ${ }^{222}$ in unum coadunauit, annis .cc.lxxviii. transactis ex quo in duas parrochias Merciorum prouincia diuisa est. ${ }^{223}$

\footnotetext{
${ }^{216} \mathrm{JWCC}\left(\mathrm{C}^{3} \mathrm{BP}^{3}\right)$, s.a. 937. Cf. WMGP, 2.85, 93.

${ }^{217} \mathrm{JW} C C\left(\mathrm{C}^{3} \mathrm{BP}\right)$, s.a. 880. Cf. WMGP, 2.86.1. under whom Athulf took office as Eadwig.

${ }^{219} \mathrm{JWCC}\left(\mathrm{C}^{3} \mathrm{BP}^{3}\right)$, s.a. 1038. Cf. WMGP, 2.74.11.

${ }^{220} \mathrm{JWCC}\left(\mathrm{C}^{3} \mathrm{BP}^{3}\right)$, s.a. 1094. Cf. WMGP, 2.74.14-15.

${ }^{221}$ JWCC, s.a. 959.

${ }^{222}$ JWCC (C ${ }^{3}$ BP), s.a. 959. Cf. WMGP, 4.176; JWBishops (C, p. 43).

${ }^{223}$ JWBishops (C, p. 43).
}

${ }^{218}$ Derived, it seems from a combination of WMGP, 2.74.4-5 and JWBishops (C, p. 39): "xii. Athulfus. Hic regis Edwii tempore eastanglię presulatum solus rexit eodemque modo illius successores." It is WMGP, 2.74.11, who dates the transfer of Elmham to Thetford to the sixth year of the reign of William I. Cf. JWCC (C $\left.{ }^{3} \mathrm{BP}\right)$, s.a. 685, who gives the king 
48. De Oswaldo Wigornensi EPISCOPO. Anno Domini .dcccc.lx. beatus Oswaldus fratruelis sanctus Odonis Dorobernensis archiepiscopi suscepit Wigornensis ecclesie presulatum. ${ }^{224}$

49. Thavestoca Construitur. Anno Domini .dcccc.lxii. cenobium in Domnania quod Theauestoca uocatur, iuxta Tay fluuium situm, Orgatus comes Domnaniensis, pater Elfride uxoris regis Edgari, constituit. ${ }^{225}$

50. Wintonię Et Mideltunię MONAChi PONUntur. Anno Domini .deccc.lxiii. sanctus Ædelwoldus Wintoniensis episcopus, iussu regis Ædgari expulsis clericis Vetus Monasterium cum monachis instituit. Anno sequenti rex Ædgarus in Nouo Monasterio Wintonię, et in Mideltunia, monachos collocauit. $^{226}$

51. Rumeseie sanctimoniales et in EXacestra monachi COnstitunntur. | Anno Domini .dccc.lxvii. rex Adgarus .ii. monasteria Rumeseie quod auus suus rex Adwardus senior construxerat, sanctimonialibus instituit, sanctamque Merewinam eis abbatissam pręfecit. Annoque sequente in Exancestre monachos instituit, et Sidemannum eis abbatis iure pretulit. ${ }^{227}$

52. ReX Edgarus In MAIORIBUs MONASTERIIS MONACHOS INSTITUI FECIT. Precepit etiam sancto Dunstano Dorobernensi, et Wulfstano Wigornensis, et Edelwoldo Wintoniensi episcopos, ut expulsis clericis, in maioribus monasteriis monachos collocarent. ${ }^{228}$ His diebus pontificatus Wigornensis sub honore beati Petri apostoli, celebris habebatur, et clerici seculariter uiuentes, inibi conuersabantur. Quos dum seruus Dei Oswaldus corrigere elaboraret, nec ullatenus proficeret, ęcclesiam in honore beatę et gloriosę uirginis MARIĘ prope ęcclesiam episcopatus construxit, in qua ipse cum sui ordinis uiris Domino seruiret. ${ }^{229}$ Anno Domini .dcccc.lxviii. Sanctus Oswaldus Wigornensis episcopus,

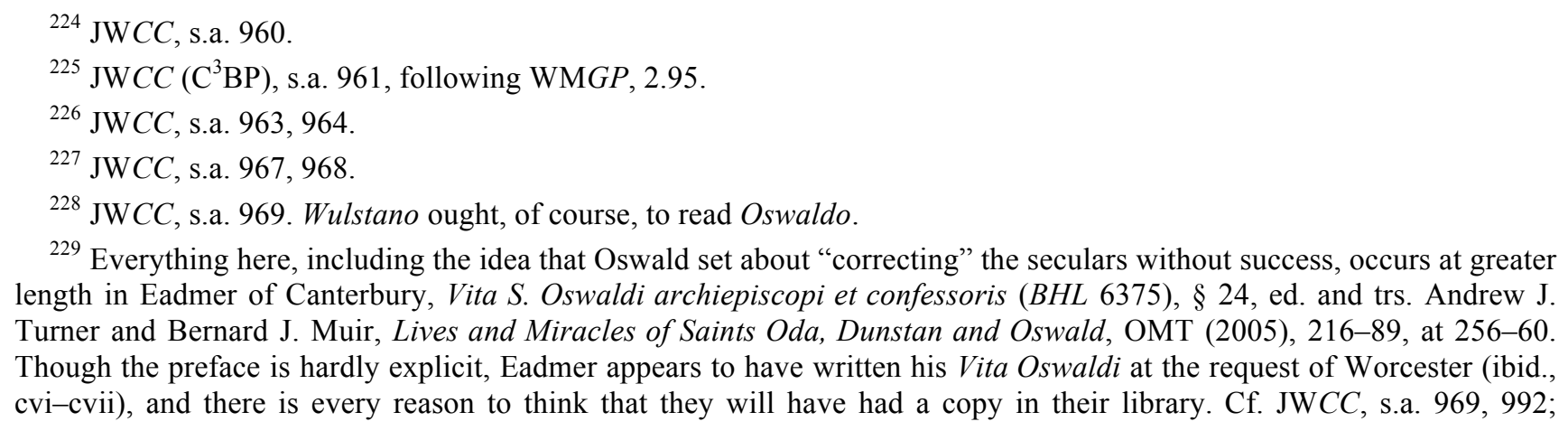

${ }^{229}$ Everything here, including the idea that Oswald set about "correcting" the seculars without success, occurs at greater length in Eadmer of Canterbury, Vita S. Oswaldi archiepiscopi et confessoris (BHL 6375), § 24, ed. and trs. Andrew J. Turner and Bernard J. Muir, Lives and Miracles of Saints Oda, Dunstan and Oswald, OMT (2005), 216-89, at 256-60. Though the preface is hardly explicit, Eadmer appears to have written his Vita Oswaldi at the request of Worcester (ibid., cvi-cvii), and there is every reason to think that they will have had a copy in their library. Cf. JWCC, s.a. 969, 992; 
clericos eiusdem ęcclesię monachilem habitum suscipere renuentes, de monasterio expulsit, consentientes monachizauit, eisque quendam Winsinum magne religionis uirum, loco decani prefecit. $^{230}$ In monasterio etiam, [fol. 12v] quod Rameseia dicitur, quod ipse et Dei amicus dux Orientalium Anglorum ÆEdelwinus a fundamentis construxerunt, monachos collocauit, ${ }^{231}$ quibus uirum prudentem Ednotham nomine pręposuit. Persora etiam monachis coadunatis quidam abbas Forthbrichtus a beato Oswaldo pręficitur. ${ }^{232}$ Sanctum Germanum, quem idem uir Dei Oswaldus de Floriaco adduxerat, Winchcumbensibus cenobitis abbatis iure pręfecit. ${ }^{233}$ Anno Domini .dccc.lxx. Sanctus Ethelwoldus extrusis clericis, Heli monachos instituit, et Brichtnothum quendam eis abbatem pręposuit. Habuit idem monasterium per ordinem abbates usque ad nonum annum regni Henrici regis Anglorum, per spacia .c.xxxix. annorum. $^{234}$

53. Oswaldus FIT ARCHIEPISCOPUS. Anno Domini .deccc.lxxii. sanctus Oswaldus Wigornensis episcopus, anno duodecimo episcopatus sui, archiepiscopus Eboracensis efficitur. ${ }^{235}$

54. ReX Edgarus terciodecimo ANNO REgNi SUI IN REGEM CONSECRATUR. Anno Domini .dcccc.lxxxii. rex Anglorum pacificus Edgarus anno ętatis sue .xxx. indictione prima, quinto idus maii, die pentecostes, a beatis episcopis Dunstano et Oswaldus, et cęteris totius Anglię presulibus in ciuitate Akemanni benedicitur, et cum maximo honore et gloria | consecratur et in regem unguitur. Interiecto deinde tempore, ille cum ingenti classe septemtrionali Britannia circumnauigata, ad

WMGP, 3.115.4-5.

${ }^{230}$ JWCC, s.a. 969.

${ }^{231}$ JWChronicula (fol. 76r); JWCC, s.a. 991. Cf. WMGP, 4.181.1.

${ }^{232}$ The source is almost certainly Eadmer of Canterbury, Vita S. Oswaldi archiepiscopi et confessoris (BHL 6375), $\S$ 17-18, ed. Turner and Muir, Eadmer: Lives and Miracles, 216-89, at 250-3. Having discussed the foundation of Ramsey with particular reference to the support provided by Ealdorman Æthelwine of East Anglia, Eadmer goes on to describe with an ablative absolute how Eadnoth, uir prudens et religiosus, was placed over it (praepositus). Then, in $\S 18$, Eadmer adds a brief mention of a miracle involving "a certain Foldbriht [whom Oswald] placed in the abbacy of the church of Pershore, which was one of the seven abbeys", which Oswald established in his diocese after expelling the clerks and their women. Cf. also the source of the latter story: Byrhtferth of Ramsey, Vita et uirtute gloriosissimi archipresulis Oswaldi (BHL 6374), 4.8, ed. and trs. Michael Lapidge, The Lives of St Oswald and St Ecgwine, OMT (2009), 2-203, at 112-7.

${ }^{233}$ This sentence contains verbal echoes of WMGP, 4.156.3, but it seems likely that both the author and William were drawing on Eadmer's Vita S. Oswaldi, from which one can see how the author might have proceeded from Foldbriht to Germanus. In $\S 18$, the chapter in which he refers to Foldbriht, Eadmer mentions Oswald's ordination of Germanus as abbot of Winchcombe; in $\S 10$, he recounts how Oswald brought (adduxerat) him to Fleury; and $\S 16$, how he put him in charge of the monks at Westbury.

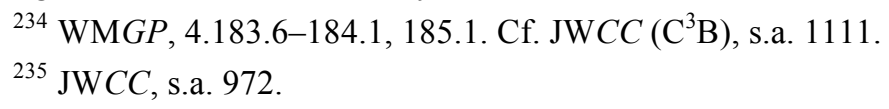


Legionum Ciuitatem appulit. Cui subreguli eius octo, Kinach scilicet rex Scottorum, Malcolm rex Cumbrorum, Macchus plurimarum rex insularum, et alii quinque Dufnal, Siuerth, Huwal, lacob, luchil, ut mandarat occurrerunt, et quod sibi fideles, et terra et mari cooperatores esse uellent, iurauerunt. Cum quibus die quadam scafam ascendit, illis ad remos locatis, ipse clauum gubernaculi arripiens, eam per cursum fluminis De perite gubernauit, omnique turba ducum et procerum simili nauigio comitante, a palatio ad monasterium sancti lohannis Baptistę nauigauit. Vbi facta oratione, eadem pompa ad palatium remeauit. Quod dum intraret optimatibus fertur dixisse tunc demum quemquam successorum suorum se gloriari posse regem Anglorum fore, cum tot regibus obsequentibus potiretur, pompa talium honorum. ${ }^{236}$

55. DE WILTUNIA. Wiltunense cenobium beata Edgitha filia regis Edgari, dulcibus exuuiis ornat. Wiltune est uicus non exiguus, super Wille fluuium positus, tantę celebritatis, ut totus pagus ab eo uocetur. ${ }^{237}$

56. ElFThrida [fol. 13r] EdWARDUM OCCIDIT ET DUO MONASTERIA CONSTRUXIT. Anno Domini .dccc.lxxx.viii. ${ }^{1}$ rex Anglorum Eadwardus, iussu nouercę suę Elfthridę, in loco qui Coruesgete dicitur, dolose occiditur. Cuius corpus apud Werham sepultum, et post duos annos incoruptum inuentum, leuatur, et Sceftesberiam delatum humatur. ${ }^{238}$ Anno Domini .dcccc.lxxix. Elfthrida uxor regis Edgari, interfectrix sancti Eadwardi regis duo monasteria Warlewelle et Ambresberi, causa penitentie construxit. ${ }^{239}$

57. De PeSte post mortem Regis EdWARdi. Anno Domini .dcccc.lxxxvii. id est anno nono interfectionis sancti regis Edwardi, duę retro seculis genti Anglorum incognitę pestes, scilicet febres hominum et lues animalium quę Anglice scitta uocatur, Latine autem fluxus interaneorum dici potest, totam Angliam plurimum uexauerat, et clade perualida tam homines afficiendo quam animalia, penitus consumendo, per omnes fines Anglię inedicibiliter deseuierunt. ${ }^{240}$

\footnotetext{
${ }^{236} \mathrm{JWCC}$, s.a. 973. JWChronicula (fols. 74v-75r), has many verbal affinities, but is not as close as JWCC.

${ }^{237} \mathrm{WMGP}, 2.87$. Cf. JWCC $\left(\mathrm{C}^{3} \mathrm{BP}^{3}\right)$, s.a. 1043.

${ }^{238}$ JWChronicula (fol. 75r). Cf. JWCC, s.a. 978, 979.

${ }^{239} \mathrm{WMGP}, 2.87 .1$. Cf. JWCC $\left(\mathrm{C}^{3} \mathrm{BP}^{3}\right)$, s.a. 1043.

${ }^{240}$ The date matches JWCC, s.a. 987, but the rest closely resembles JWChronicula (fol. 75v), the only place where JW connects this disaster with the murder of Edward the Martyr: "In cuius necis ultionem duę retro seculis Anglorum genti incognite pestes, scilicet... inedicibiliter deseuierunt".
} 
58. Alfricus archiepiscopus monachos in CANCIA POSUIT. Anno Domini .dcccc.xciiii. Alfricus qui erat Wiltunensium episcopus, post beatum Dunstanum tercius Dorobernensis archiepiscopus, clericis a Cantia perturbatis monachos induxit. ${ }^{241}$

59. Episcopatus Lindisfarnensis mutatur et Dani Angliam Uastant. | Anno Domini .dcccc.xcv. regnante rege Anglorum Afelredo, corpus sancti Cuthberti sicut oraculo cęlesti pręmonstratum fuerat, de loco qui Cunegaceastre dicitur, qui post Lindisfarnensem insulam ubi primum sedes episcopalis fuerat, secunda sedes habebatur, in Dunholmum perlatum, atque sedes episcopalis ibidem est constituta. Iccirco sanctus Beda Lindisfarnensem posuit, ubi prima erat sedes episcopalis. Tempore nanque Bedę nulla erat fama Dunholmi. ${ }^{242}$ Ipso rege Eielredo regnante, ciuitatum urbium oppidorum uillarumque crematione, agrorum deuastatione, misera hominum strage, a Danis hanc terram totam deuastantibus, maxima facta est miseria. Nam ut ipsi Dani cum Anglis pacem tenerent, nunc tria milia librarum, nunc .x. milia quingentas, nunc .xvii.m. nunc .xxiiii.m. nunc .xxxv.m. nunc .Ixxii.m. librarum a tota Anglia rege iubente soluebantur. ${ }^{243}$

60. De passione Sancti Aelfegi. Anno Domini .m.xi. Danorum exercitus Cantuariam circumuallantes obsederunt. Ecclesia Christi spoliata comburitur, grex monachilis, et turba uirilis, sed et muliebris, nec non et infantilis decimatur. Nouem trucidantur, decimus uite reseruatur. Monachis quatuor et .dccc. uiris decimatorum summa perficitur Elfegus archiepiscopus qui primo [fol. 13v] in monasterio cui Deorhirste uocabulum est, monachilem susceperat habitum, et post Bartonicus abbas extiterat, postmodumque Edelwoldo Wintoniensi episcopo successerat, ${ }^{244}$ uinctus extrahitur, impellitur, grauiter sauciatur, ${ }^{245}$ ad Danorum concilium pertrahitur, lapidibus, ossibus, bouinis capitibus obruitur, ad ultimum securi capiti eius infixo, obdormiuit in Domino. ${ }^{246}$

\footnotetext{
241 There is agreement here with the earlier versions of WMGP (i.e. the $\beta$-text), most notably in the form in which it occurs in London, British Library, MS Harley 3641-a late twelfth-century copy from Byland Abbey in Yorkshire. In $\S$ 20.1 it reads qui clericis a Cantuaria perturbatis monachos induxit. The other witnesses to the $\beta$-text have proturbatis instead of perturbatis. Cf. JWCC (C BP), s.a. 995; JWBishops (C, p. 41).

242 JWCC, s.a. 995. Cf. JWChronicula (fol. 76rv).

243 JWChronicula (fols. 75v-76r).

244 JWCC, s.a. 984.

245 JWCC, s.a. 1011, with material from 984.

${ }^{246}$ JWCC, s.a. 1012. Cf. JWChronicula (fol. 77r).
} 
61. Eadmundus et Cnutus in Reges eliguntur. Anno Domini .m.xvi. rex Anglorum Eielredus uita decessit. Cuius post mortem, quique nobiliores Anglię, Cnutum Suani filium elegerunt, ciues uero Lundonienses clitonem Eadmundum $\backslash$ Irenside $/{ }^{m}$ in regem leuauerunt. Hinc inter ambos reges atrocissima pugna quinquies bellatum est. Tandem inter eos regnum diuiditur, coronam uero regni Edmundus sortitur, sed illo defuncto, Cnutus rex Anglorum efficitur. ${ }^{247}$

62. Apud Sanctum Edmundum monachi ponuntur. Anno Domini .m.xxxii. Cnutus rex Anglorum communi consilio archiepiscoporum episcoporum et optimatum suorum, ab ęcclesia sancti Eadmundi regis et martyris presbyteros, qui inibi inordinate uiuebant, eiecit, et monachos posuit. Ipsam uero ęcclesiam iussu regis eiusdem Eyelnoth/us Dorobernensis archiepiscopus dedicauit, et $\underline{\text { abbatem constituit, quem Faldwinus Lundo|niensis episcopus consecrauit. }}{ }^{248}$

63. De sancto Wlfstano Wigornensi episcopo. Regibus Cnuto et Haraldo et Hardecnuto filius eius de medio factis, anno Domini .m.xliii. Eadwardus successit, regis Edelredi filius, cuius anno .xix. Wulfstanus uenerabilis pontifex Wigornensi ęcclesię pręficitur. Hic Domino amabilis, regione Merciorum in prouincia Warewicensi tempore regis Cnuti, parentibus religiosis oriundus, patre Ęthelstano, matre Wulueua nomine, in monasterio quod Burch uocatur, litteris et ecclesiasticis officiis optime est imbutus. Qui ambo parentes eius in tantum religioni studebant, ut longe ante finem uitę castitatem professi, se ab inuicem separantes, sub sanctę conuersationis habitu uitam consummare gauderent. Quorum exemplo et ipse adolescens incitatus, matre id maxime persuadente, seculum reliquit, ac in eodem Wigornensi monasterio, quo et ante pater Domino seruierat, monachicum habitum et ordinem a uenerabili Brichtego eiusdem ęcclesię episcopo suscepit. A quo etiam tam ad diaconatum quam ad presbiteratum ordinatus est. Statimque in ipso inicio omni religione comptam uitam arripiens, in uigiliis, ieiuniis, orationibus, et omni uirtutum genere, clarus apparuit. Hinc per [fol. 14r] singula officia gradatim promo $<\mathrm{t}>\mathrm{us}$, elapso tandem aliquando tempore Aldredo eiusdem ęcclesię episcopo ad Eboracensem archiepiscopatum promoto, ipse uenerabilis Wulstanus iam tunc decanus, ipsius Wigornensis ęcclesię episcopatum, licet satis

\footnotetext{
${ }^{247}$ JWChronicula (fols. 77v-78r): "Post mortem cuius quique nobiliores Anglię sibi in dominum et regem Canutum elegere, et fidelitatem ille illis illique iurauere. Verum ciues Lundonienses clitonem Eadmundum in regem leuauere. Hinc inter ambos reges atrocissima pugna quinquies bellatum est...”. Cf. JWCC, s.a. 1016 (esp. 2:484).

${ }^{248}$ Acta of William I, no. 39 (p. 206). For further explanation, see section three of the introduction above.
} 
renitens pręficitur, dieque natiuitatis sanctę MARIĘ a pręfato Aldredo consecratur. ${ }^{249}$

64. Rex Eduardus obitt, cui succedit Haroldus et paulo post Willelmus. Anno Domini .m.lxx. rex Anglorum Edwardus anno regni sui .xxii. ęcclesiam apud Westmonasterium quam ipse a fundamentis construxerat, die sanctorum Innocentium in honore sancti Petri apostoli cum magna gloria dedicari fecit, et .xxiii. annis, mensibus sex, et .xxvii. diebus emensis postquam regia potestate pręfuit Anglis Saxonibus, nonas ianuarii feria quinta obiit Lundonię. Cui Haraldus Godwini ducis filius successit, sed nouem mensibus et totidem diebus exactis ex quo regnare cępit, a Willelmo Normannorum comite qui cum innumera multitudine equitum, fundibalariorum, sagittariorum peditumque Angliam uenerat, apud Hastingam in bello occisus est, regnumque Anglorum Willelmus optinuit, ${ }^{250}$ et ob remedium animarum omnium qui ex utraque parte ceciderant, in eodem | loco ubi Angliam debellauerat, monasterium fundauit, et in honore Sancti Martini ędificari fecit, multa ibi preciosa cum uiuus tum moriturus delegans. Altare est in loco ubi Haroldi patrie caritate occisi, cadauer repertum est. ${ }^{251}$

65. De concilio Wintonię IN QUO Quidam episcopi DegRadantur, QUidam FiUnt. Anno Domini .m.lxx. regni uero Willelmi regis Anglorum quarto, concilium magnum in octauis pasche, .iii. idus aprilis celebratum est Wintonię, iubente et pręsente Willelmo rege, domno papa Alexandro consentiente, et per suos legatos Ermenfredum Sedunensem episcopum, et presbyteros Iohannem et Petrum cardinales sedis apostolicę, suam auctoritatem exhibente. In quo concilio Dorobernię /Stigandus/ archiepiscopus degradatus est tribus ex causis, scilicet quia episcopatum Wintonię cum archiepiscopatu iniuste possidebat, et quia uiuente archiepiscopo Roberto non solum archiepiscopatum sumpsit, sed etiam eius pallio quod Cantuarię remansit, usus est, et post a Benedicto quem sancta romana ęcclesia excommunicauit, eo quod pecuniis sedem apostolicam inuasit, et pallium accepit. Episcopi alii et abbates degradantur, in quorum locum Normannicę gentis personę substituuntur. Verentibus omnibus regis austeritatem, uir uenerandus Wulstanus Wigornen[fol. 14v]sis episcopus, possessiones quamplures sui episcopatus Aldredo archiepiscopo, sua potentia detentas, qui tunc eo defuncto in regiam postestatem

\footnotetext{
${ }^{249}$ JW Chronicula (fol. 94rv). Cf. JWCC, s.a. 1062.

${ }^{250}$ JWChronicula (fol. 95rv). Cf. JWCC, s.a. 1065 and 1066.

${ }^{251} \mathrm{JWCC}\left(\mathrm{C}^{3} \mathrm{BP}^{3}\right)$, s.a. 1123. Cf. WMGP, 2.97.
} 
deuenerant, constanter proclamabat, expetebat, iusticiamque inde fieri ab omnibus concilio pręslid/entibus flagitabat. At quia Eboracensis ęcclesia non habens pastorem qui pro ea loqueretur, muta erat, iudicatum est ut ipsa querela six remaneret, quousque archiepiscopus qui ei responderet substitueretur. Die pentecostes apud Windlesoram rex dedit Baiocensi canonico Thomę Eboracensem archiepiscopatum et Walkelino capellano suo episcopatum Wintonię, quem Aremenfredus Sedunensis episcopus apostolicus legatus ordinauit. Ascito quoque de Normannia Cadomensi abbati Lanfranco, uiro undecumque doctissimo, dedit rex archiepiscopatum Cantuarię, quem Giso Willensis et Walterius Herefordensis episcopi, ambo prius a Nicholao papa ordinati, ordinauerunt, et Lanfrancus postea Thomam Eboracensem consecrauit episcopum. ${ }^{252}$

66. De primatu Dorobernie et SUBIECTIONe EbORACI. Anno Domini .m.lxxii. pontificatus autem domni Alexandri pape .xi. regni Willelmi gloriosi regis Anglorum et ducis Normannorum $\cdot \mathrm{vi}^{\text {to }}$. ex precepto | eiusdem Alexandri pape, annuente eodem rege in presentia ipsius et episcoporum atque abbatum, uentilata est causa quam Lanfrancus Dorobernensis archiepiscopus super Eboracensem ecclesiam iure ecclesię sue proclamabat, et de ordinationubus quorundam episcoporum, de quibus ad quam specialiter pertinerent certum minime constabat. Et tandem aliquando diuersis diuersorum auctoritatibus probatum et ostensum est quod Eboracensis ecclesia Cantuariensi subiacere debeat, eiusque archiepiscopi ut primatis totius Britannię dispositionibus, in his quę Christianę religioni pertinent, obedire in omnibus. Subiectionem uero Dunholmensis episcopi atque omnium regionum a terminis Licifeldensis episcopii et Humbre magni fluuii usque ad extremos scotię fines, et quicquid ex hac parte prędicti fluminis ad parrochiam Eboracensis ecclesię iure pertinet, Cantuariensis metropolitanus Eboracensi archiepiscopo eiusque successoribus in perpetuum optinere concessit, ita ut si Cantuariensis archiepiscopus concilium cogere uoluerit, ubicumque ei uisum fuerit, Eboracensis archiepiscopus sui pręsentiam cum omnibus sibi subiectis ad nutum eius exhibeat, et eius canonicis preceptionibus obediens existat.

\footnotetext{
${ }^{252}$ JWChronicula (fol. 96rv). Cf. JWCC, s.a. 1070.
} 
[col. 15r] Quod autem Eboracensis archiepiscopus professionem Cantuariensi <archiepiscopo> etiam cum sacramento facere debeat, Lanfrancus archiepiscopus ex antiqua antecessorum consuetudine ostendit, sed ob amorem regis Thomę archiepiscopo sacramentum relaxauit, scriptamque tamen professionem recepit, non pręiudicans successoribus suis qui sacramentum cum professione a successoribus Thomę exigere voluerint. Si archiepiscopus Cantuariensis uitam finierit, Eboracensis archiepiscopus Doroberniam ueniet, et eum qui electus fuerit cum cęteris pręfate ecclesię episcopis, ut primatem proprium iure consecrabit. Quod si Eboracensis archiepiscopus obierit, is qui ei successurus eligitur, accepto a rege episcopatus dono, Cantuariam uel ubi Cantuariensi archiepiscopo placuerit accedet, et $\mathrm{ab}$ ipso canonico more ordinabitur. Huic constitutioni consenserunt pręfatus rex, et ipse archiepiscopus Lanfrancus Cantuariensis, et Thomas Eboracensis, et cęteri qui interfuere episcopi. Ventilata est autem hec causa prius apud Wentanam ciuitatem in paschali festiuitate in capella regis que sita est in castello, postea in uilla regia que dicitur Windlesore, ubi et finem accepit in presentia regis, episcoporum, abbatum, et di|uersorum ordinum qui conuenerant ad curiam ad Pentecosten. $\Psi$ Signum Willelmi regis. $\mp$ Signum Matildis reginę. Subscripsit autem Hubertus sanctę Romanę ecclesię lector, Alexandri pape legatus. ${ }^{253}$ Subscripserunt et pręfati archiepiscopi subscribentibus et eidem dispositioni consentientibus, omnibus tam episcopis quam abbatibus Anglię.

67. DE CONCILIO LUNDONENSI. Anno Domini .m.lxxv. regnante glorioso Anglorum rege Willelmo, anno regni eius nono, congregatum est Lundonię in ecclesia Pauli apostoli concilium totius Anglie episcoporum et abbatum, et multarum religiosi ordinis personarum, iubente atque eidem pressidente Lanfranco Cantuariensi archiepiscopo, Willelmo Lundoniensi episcopo, Gosfrido Constantiniensi episcopo, qui cum transmarinus

\footnotetext{
1.27 .

53 The present version of this document is significantly closer to that found in WMGR, 3.298.1-6, than that in WMGP,
} 
esset episcopus, in Angliam habens multas possessiones cum ibidem cęteris residebat, Walkelino Wintoniensi, Heremanno Scireburnensi, Wulstano Wirecestrensi, Waltero Herefordensi, Gisone Willensi, Remigio Lincolliensi, Herefasto \Hereberto $/^{\mathrm{n}}$ Norwicensi, Stigando Seleseiensi, Osberno Exoniensi, Petro Lichesfeldensi, Rofensis ęcclesia per idem tempus pastore carebat. Lindis[fol. 15v]farnensis qui et Dunelmensis episcopus canonicam excusationem habens, concilio adesse non poterat. Et quia multis retro annis usus conciliorum obsoleuerat, renouata sunt nonnulla, quę antiquis canonibus noscuntur diffinita. Ex concilio igitur Toletano .iiii. Milleuitano atque Bracharensi, statutum est ut singuli secundum ordinationis suę tempora sedeant, preter eos qui ex antiqua consuetudine, siue ecclesiarum suarum priuilegiis, digniores sedes habent. De qua re interrogati sunt senes et ętate prouecti, quid uel ipsi uidissent, uel a maioribus accępissent. Super quo responso petitę inducię ac concesse sunt in crastinum. Crastina autem die perhibuere, quod Eboracensis archiepiscopus ad dexteram Cantuariensis sedere debeat, Lundoniensis episcopus ad sinistram, Wentanus iuxta Eboracensem. Si uero Eboracensis desit, Lundoniensis episcopus ad dexteram, Wentanus ad sinistram. ${ }^{254}$

68. Qualiter ReX Willelmus Primus totam Angliam DesCribi fecit. Anno Domini .m.lxxxvi. Willelmus rex Anglorum misit per omnes prouincias Anglię, et fecit inquiri quot haberentur hidę in tota Anglia $^{\circ}$ et quantum rex haberet in terris et iumentis et bestiis, et quas consuetudines ipse haberet in unaquaque prouincia, et quos redditus | per annum. Hoc idem fecit fieri de terris et redditibus omnium ęcclesiarum et omnium baronum suorum, et cuius precii essent et quantum tunc reddidissent et quantum tempore regis Edwardi reddere possent. Et hoc ita strictim peractum est, ut non remaneret in tota Anglia vel una hida nec una virgata terre nec bos nec vacca nec porcus unus, qui non esset scriptus in breviatione illa, omnesque scripturę omnium harum rerum repraesentatę sunt regi. Qui precepit ut omnes scriberentur in uno uolumine et poneretur uolumen illud in thesauro suo Wintonię et servaretur ibi. ${ }^{255}$ Anno uero sequente, quinto iduum

\footnotetext{
${ }^{254} \mathrm{WMGP}, 1.42 .7 \beta-42.9$. Cf. WMGR, 3.300.3-301.

${ }^{255}$ This account of the Domesday Survey comprises a close translation of that found in the E-text of the Anglo-Saxon
} 
septembrium, in Normannia, uita decessit, annis .xx. mensibus decem et .xxviii. diebus completis, quibus genti Anglorum prefuit. ${ }^{256}$

69. De REGE WiLlelmo SECUNDO. Successit ei filius eius Willelmus et anno primo regni ipsius, commota est fere tota Anglia, et maxima infidelitate repleta, ita ut excellentiores principes totius regni, excepto Lanfranco archiepiscopo, uellent tradere regem dominum suum, et in regem habere fratrem eius Robertum. In hac traditione fuit Odo Baiocensis episcopus comes totius Cantię, Goffridus episcopus, Willelmus luel Rannulfus $/^{p}$ Dunelmensis episcopus, et ut dictum est, omnes primi regni. Quę coniuratio facta est in quadragesima. Mox post Pascha cę[fol. 16r]pit quisque circa se uastari, rapere, depredari omnia, castella munire fosso et uictu. Goffridus episcopus Constantiensis, et Robertus de Mumbrai iuerunt Brigstowe, ubi habebant castrum fortissimum, et omnia deuastabant usque ad Bathum. Bernardus de Nouo Mercatu, et Rogerus de Laceio qui iam super regem inuaserat Herefordam, et Radulfus de Mortuo mari, coniurationis socii, cum hominibus comitis Rogeri de Scrobesberia, congregato magno Normannorum Anglorum et Walensium exercitu, Wigornensem irruperunt prouinciam, affirmantes se igne crematuros ipsam ciuitatem Wirecestre, spoliaturos Dei et sancte MARIE ęcclesiam, grandem de incolis regis fidelibus sumpturos uindictam. His auditis, uir domino et hominibus amabilis, et regi ut domno terreno omnio fidelis, Wigornensus episcopus Wulfstanus, turbatur. Respirans tandem de Dei misericordia, parat se uiriliter ut stet pro populo et ciuitate sua. Hostibus igitur ad debellandum parantibus arma, ipse nichilominus pro imminenti periculo fudit precamina, ne desperent de Deo suos frequenter exhortans. Normanni interim ineuntes consilium, rogant ipsum episcopum ut ab ęcclesia transiret in castellum, tutiores se afferentes de eius pręsentia, si maius incumberet periculum. | diligebant enim eum ualde. Ipse autem ut erat mirę mansuetudinis, et pro regis fidelitate et eorum dilectione, penitentibus acquieuit. Interea audenter in arma se parat episcopalis familia. Conueniunt castellani et omnium ciuium turma, occurrere parati hostibus ex altera parte Sabrine fluminis, si tantum annueret episcopus. Intererat quidam consilio prouidus Wido Persorensis abbas. Hunc ultro se

Chronicle, s.a. 1085a, ed. Susan E. Irvine, The Anglo-Saxon Chronicle: A Collaborative Edition, vol. 7, MS E (Cambridge, 2004), 94. It differs from that version most significantly in its references to William I's interest in the sums that King Edward had collected and to the production of a single volume that was to kept in the royal treasury at Winchester. An account in almost exactly the same words occurs in JWChronicula (fol. 98r), differing most curiously with the nuance that William was interested in what properties could render to the king in the time of Edward the Confessor.

${ }^{256}$ JWCC, s.a. 1087 (3:46). 
offerentem-ius pontificale creans ad tempus militem—statuit belli ducem, totum in Deo et in orationibus episcopi confidentem. Parati igitur et armis instructi, episcopum ad castellum habent obuiam, quam optabant requirunt licentiam. Quibus benigne annuens, "Ite", inquit, "filii, ite in pace, ite securi, cum Dei benedictione et nostra. Confidens in Domino, spondeo uobis, quidam nec gladius, non quicquam infortunii, oberit uobis hodie, state in fidelitate regis pro populi et urbis presidio. His animati, pontem reparatum transeunt, hostes de longe accelerantes prospiciunt, in quibus certe iam magna belli cupido feruebat. Nam contumaciter, episcopi tempnentes mandata, in possessionibus eius igne posuerunt. Hinc episcopus ingenti dolore concutitur, et de ęcclesię dampnis conquestus, consilio accepto, [fol. 16v] coatus etiam a circumstantibus graui hostes percussit anathemate. Mira res, hostes namque acsi insani uagantes per agros, tanta membrorum feriun $<\mathrm{t}>$ ur debilitate, tanta luminis orbitate, ut uix arma ferent, uix socios agnoscerent. uix aduersantes sibi discernerent. Iamque episcopali et regali milite in pugnam hastam uibrante, iam presule cum Moyse manus in celum leuante, cedunt pedites, capiuntur milites cum Normannis tam Angli quam Gualenses. Cęteris debilis fuga presidium, episcopo et suis diuina uictoria fert tripudium. Ubi ut ferunt numero quingenti de hostibus ceciderunt. Rex deinde Willelmus maxime Anglorum auxilio, potitur de inimicis uictoria. ${ }^{257}$

70. De occisione Regis Willelmi. Rex Anglorum Willelmus in Nova Foresta que Ytene dicitur. quarto nonas augusti. sagitta percussus obiit. Regnauit autem .xiii. annis minus .xxx.viii. diebus. Cui successit iunior frater eius Henricus, \& nonas augusti die dominico apud Westmonasterium a Mauricio Lundoniensi in regem consecratur, sed a Thoma Eboracensi archiepiscopo quoniam quidem Anselmus Cantuariensis archiepiscopus Anglia exulans deerat, coronatur. ${ }^{258}$

71. De InCENDIO Wigornię. Anno Domini .m.c.xiii. ciuitas Wigornia cum principali ecclesia et omnibus aliis, et castello .xiii. kl. iulii, feria .v. igne | cremata est. $^{259}$

72. De Heliensi episcopatu. Anno regni sui nono, rex Henricus abbatiam Heliensem in sedem episcopalem mutauit. ${ }^{260}$ Eodem etiam tempore Nouum Monasterium quod infra muros Wintonię

\footnotetext{
257 This version is closest to JWChronicula (fols. 98v-100r). The version in JWCC, s.a. 1088 (3:54, 56), differs greatly in length, arrangement and detail; but the present version shares some variants.

258 JWCC, s.a. 1100 (3:92, 94). JWChronicula (fols. 105v-106r), is similar, but not as close.

${ }^{259}$ Either JWCC, s.a. 1113, or JWChronicula (fol. 109v).

${ }^{260}$ JWCC, s.a. 1109 (3:118).
} 
erat, extra murum construi iussit. ${ }^{261}$ Matildis regina Anglorum apud Westmonasterium kal. Maii obiit, ubi et sepulta est. ${ }^{262}$

73. DE MORTE FILII REGIS. Rex Anglorum Henricus omnibus prospere ad uelle peractis, anno Domini .m.c.x[x]. a Normannia in Angliam rediit. Quem Willelmus filius eius sequi gestiens, nauem ingreditur, copiosa nobilium militum puerorum ac feminarum multitudine comitatus. Hi portu maris euecti, miraque aeris serenitate freti, freto illapsi. in modico nauis qua uehebantur rupem incurrens euersa est, et omnes qui in ea erant, excepto rustico uno qui mira Domini gratia uiuus euasit, marinus fluctibus sunt absorbti. Quę res et regis prospero nauigio Angliam uenientis, et omnium qui audierunt mentes exterruit atque turbauit, et de occultis Dei iudiciis in ammiratione concussit. ${ }^{263}$

74. De CONSECRATIONE ĘCCLESIĘ THEOKESBERIĘ. Anno Domini .m.c.xxi. principalis ęcclesia Theobkesberie ab episcopus Teoldo Wignornensi. Ricardo Herefordensi. Vrbano Glamorgarensi. et Gregorio Dudlinensi .ix. kl. nouembris [fol. 17r] feria secunda, consecrata est cum magno honore. ${ }^{264}$ Theoulfus Wigornensis episcopus uita decessit, cui Symon succedens, a Willelmo Cantuariensi archiepiscopo Cantuarię consecratus est. ${ }^{265}$

75. INCIPIT DE QUIBUSDAM PRINCIPALIBUS CENOBIIS. In Sumersetensi pago est episcopatus antiquitus abbatia Bathonię. ${ }^{266}$ Sunt ibi et abbatię, Glastonia cęterarum abbatiarum Anglię antiquior, ubi nonnulla corpora sanctorum requiescunt, inter quos beatus Patricius Ybernensium apostolus, et sanctus Benignus ipsius discipulus, sanctus etiam Aidanus, et sanctus Ceolfridus abbas confessores, et sanctus martir Indratus cum .ix. sociis martiribus, sancta Hilda et sancta Elfgiua uirgines, et multi alii. ${ }^{267}$ Sunt et in eodem pago Sumersetensi, Miceleneie et Ethelingeie abbatię, ${ }^{268}$ et

${ }^{261}$ JWCC, s.a. 1111. Cf. JWChronicula (fol. 109v), which is fuller, but slightly different.

262 Either JWCC, s.a. 1118, or JWChronicula (fol. 111v).

${ }^{263}$ Either JWCC, s.a. 1120 (3:146, 148) or JWChronicula (fols. 112v-113r).

264 JWCC, s.a. 1121 (3:150); JWChronicula (fol. 113r).

265 JWCC, s.a. 1123, $1125(3: 154,158)$.

${ }^{266}$ Possibly influenced by WMGP, 2.90.3.

${ }^{267}$ This account of the relics claimed by Glastonbury Abbey may well have been inspired by similar material in the works of William of Malmesbury, since he mentions almost all of these saints: see WMGP, 2.91.6-9; WMGR, 1.20.2, 21.1, 23, 24, 35C.3, 50.5; and idem, De antiquitate Glastonie ecclesie, esp. $\S \S 20-22$, ed. and trs. John Scott, The Early History of Glastonbury: An Edition, Translation and Study (Woodbridge, 1981), 68-70. There are, however, two important differences of detail. The present item says that Indracht had nine companions, but William's accounts of that saint clearly state that he went he went to Rome with "seven high-born companions": WMGP, 2.91.7; idem, Vita S. 
apud Montem Acutum cenobium, ubi honestę religionis et Cluniacensis professionis congregatio monachorum habetur. ${ }^{269}$

76. DE DoRSATENSI PAGO. In Dorsetensi pago sunt abbatie Cerneliensis, Midelensis, et Abbudesberiensis, monachorum; sed et Scireburnensis dudum episcopatus, nunc per Rogerum episcopum Seresberiensem consensu Henrici regis facta abbatia monachorum, et Sceaftoniensis sanctimonialium. In quo pago olim colebatur deus Helit, sed predicans uerbum Dei Sanctus Augustinus, uidit mentis oculis diuinam adesse presentiam| hylarisque factus, ait, "Cerno Deum, qui nobis retribuet gratiam." Euentus igitur uel potius uerbum, Cerneliensi loco indidit uocabulum ut uocaretur "Cernel", ex duobus uerbis Hebraico et Latino quod Deus dicatur Hebraice "El". Ibi succedentibus annis Edwoldus frater Sancti Edmundi regis et martyris, uitam heremiticam solo pane et aqua triuit. Post uero actam uitam, magna sanctitatis opinione ibidem sepelitur. Cui succedens Ethelwoldus homo prediues, cenobiium ibidem in honore sancti Petri apostoli construxit. ${ }^{270}$

77. DE Wiltunensi PAGO ET BeRCACENSI. In Wiltunensi pago sunt cenobia, Malmesbiria monachorum, Wiltonia et Ambresbiria sanctimonialium. In Bercacensi pago sunt monasteria duo, Abbedoniense et Redingense. Abbenduniam Cyssa pater Yne fundauit. Redinges quondam fuit cenobium sanctimonialium, quod rex Henricus pro indicta sibi penitentia restaurare intendens, duo olim alia diruta Leminstre et Celsiq

Indrachti, ed. and trs. Winterbottom and Thomson, Saints' Lives (n. 133 above), 368-81, at 370. The author appears, therefore, to have known the Passio S. Indracti et sociorum eius (BHL 4271), § 1, ed. Michael Lapidge, "The Cult of St Indract at Glastonbury," in Dorothy Whitelock, Rosamund McKitterick, and David N. Dumville (eds), Ireland in Medieval Europe: Studies in Honour of Kathleen Hughes (Cambridge, 1982), 199-204, at 199, an eleventh-century life which provides Indracht with nine colleagues. The other difference lies in the addition of the virgin called Elfgiua, "Flfgifu". She is perhaps to be equated with the Glastonbury saint whom William of Malmesbury (or an interpolator?) names in De antiquitate Glastonie, § 22, as Ealfleda, a "virgin whose flesh and bones are still whole... and whose hair shirt and holy robe have not rotted". Cf. JWCC $\left(\mathrm{C}^{3} \mathrm{BP}\right)$, s.a. 688; Martin Howley, "Relics at Glastonbury Abbey in the Thirteenth Century: The Relic List in Cambridge, Trinity College R.5.33 (724), fols. 104r-105v," Mediaeval Studies 72 (2009): 197-234.

${ }^{268} \mathrm{JWCC}\left(\mathrm{C}^{3} \mathrm{BP}^{3}\right)$, s.a. 937, but the addition of Æthelney suggests an awareness of the source, WMGP, 2.90.6, because JWCC does not mention that house at this point.

${ }^{269}$ See section five of the introduction above.

${ }^{270} \mathrm{JWCC}\left(\mathrm{C}^{3} \mathrm{BP}^{3}\right)$, s.a. 1043. Cf. WMGP, 2.84.1-4. On the sources of this legend, see Tom Licence, "Goscelin of St Bertin and the Life of St Eadwold of Cerne," Journal of Medieval Latin 16 (2006): 182-207. 
adiunxit, et monachis instituit. ${ }^{271}$

78. DE OXINEFORDENSI PAGO. In Oxenefordensi ciuitate fuit antiquitus cenobium sanctimonialium, in quo requiescit sancta uirgo Fredesuitha. Que sponsi cęlestis amore, terreno sponso despecto, statuit monasterium, quod tempore regis Egelredi, Danis neci adiudicatis, [fol. 17v] et in illud confugientibus cum ipsis flammis absumptum est, sed non multo post ab eodem rege restitutum est. Sed nunc tempore Henrici Anglorum regis, Rogerius Seresberiensis episcopus ipsum locum $W$ imundo dudum regis capellano dedit, ubi et ipse canonicus factus, nonnullos ibidem canonicos canonice uicturos instituit. ${ }^{272}$

79. De Bedefordensi Pago et Hunteduniensi. In pago Bedefordensi est abbatia Sancti Albani prothomartyris Anglorum. ${ }^{273}$ In Hunteduniensi pago sunt Ramesera, Burch, et Cruland abbatię. Burch olim Medeshamsteda dicebatur, sed postquam Kenolphus abbas locum muro cinxit, a similitudine urbis Burch uocatus est. ${ }^{274}$ Duę ibi sanctę uirgines Kinetrida et Kineswitha, Pendę regis filie requiescunt. Est et ibi brachium Sancti Oswaldi regis, neruis carne et cute integrum. 275 Rameseiensis ecclesie fundator fuit Sanctus Oswaldus Eboracensis archiepiscopus, cooperante Egelwino quodam ${ }^{276}$ Anglorum comite. Ibi Sanctus Felix Orientalium Anglorum primus episcopus, et duo germani Ethelredus et Ethelbertus, et Sanctus Yuo Persorensis episcopus requiescunt. Cruland est insularum una iacentium in illo tractu Orientalium stagnorum que a meditullio terre orientia et per.c. et eo amplius milia fluentia, in mari cum multis et magnis fluminibus impetu suo preci|pitantur. Ibi sanctus Guthlacus requiescit, et sanctus Neothus, Erkenwoldi Lundoniensis episcopi discipulus, Walthes quoque comes a Willelmo rege innocenter occisus, ibi sepelitur. Prior ipsius loci retulit se corpus ipsius

\footnotetext{
${ }^{271} \mathrm{JWCC}\left(\mathrm{C}^{3} \mathrm{BP}^{3}\right)$, s.a. 1043. Cf. WMGP, 2.87.1, 88.1, 89.1-2.

${ }^{272} \mathrm{JWCC}\left(\mathrm{C}^{3} \mathrm{~B}\right)$, s.a. 1048 . Cf. WMGP, 4.178.

${ }^{273} \mathrm{JWCC}\left(\mathrm{C}^{3} \mathrm{~B}\right)$, s.a. 1048, which has Hertfordensi instead of Bedefordensi, but Hertfor - is written over an erasure. Cf. WMGP, 4.179.1.

${ }^{274} \mathrm{JWCC}\left(\mathrm{C}^{3} \mathrm{~B}\right)$, s.a. 1048. Cf. WMGP, 4.180.1.

${ }^{275} \mathrm{JWCC}\left(\mathrm{C}^{3} \mathrm{~B}\right)$, s.a. 1050. Cf. WMGP, 4.180.3.

${ }^{276} \mathrm{WMGP} \S \S 181.1$, adds orientalium.
} 
multo post occisionem contrectasse, caput reliquo corpori unitum, rubra tantum linea signum cedis ostentante uidisse, et ideo eum pro sancto teneri. ${ }^{277}$

80. De Wigornensi PAgO ET GLAVECESTRENSI. In Wigornensi pago est monasterium quod Persora dicitur, et aliud quod dicitur Euesham a sancto Egwino edificatum. ${ }^{278}$ Est et ibi Maluernense monasterium, quod per antifrasim uidetur sortitum esse uocabulum. Non enim male sed bene ibi religio creuit, ubi ad immortale commodum, mortalium rerum penuria monachos trahit. ${ }^{279}$ In eadem diocesi Glauecestrensis prouincice est monasterium Glouecestre et monasterium Wincelecumbe in eodem pago situm. ${ }^{280}$ Monasterium etiam quod Theodekesberia uocatur, ipsa continet prouincia. Quod Theodocus quidam, quondam construxit, a quo et nomen accepit. Quod etiam processu temporis Robertus filius Hamonis fauore suo prouexit, et pulchre exaltauit. Vbi consilio domni Wulstani Wigornensis episcopi, Wintoniensis monachus Geroldus ecclesię eiusdem abbas [fol. 18r] monachos qui ante apud Craneburnam fuerunt locauit, Theodekesberia dicitur, quasi Dei genitricis curia. ${ }^{281}$

81. De Herefordensi PAgo. In Herefordensi pago est cenobium quod dicitur Wineloc, ubi dudum sanctimonialium habitatio erat, ubi requiescit beata uirgo Milburga, neptis Pende regis Merciorum. Quem locum omnino desertum, Rogerus comes de Monte Gomerico monachis Cluniacensibus ibidem locatis reparauit. Scrobesberiense monasterium, idem comes statuit, ibique monachos ex Sagio locauit. ${ }^{282}$ Cestrense cenobium Hugo comes Cestrensis construxit. ${ }^{283}$

82. De PROGENITORIBUS ET FILIIS Woden. ${ }^{284}$ Woden fuit filius Fredewoldi, qui fuit Frealaf, qui

\footnotetext{
${ }^{277} \mathrm{JWCC}\left(\mathrm{C}^{3} \mathrm{~B}\right)$, s.a. 1050; WMGP, 4.181.1-6, 182.1-4, 6. The language is occasionally closer to WM, but the material occurs in the same order as in JW.

${ }^{278} \mathrm{JWCC}\left(\mathrm{C}^{3} \mathrm{~B}\right)$, s.a. 1095. Cf. WMGP, 4.159-160.1.

${ }^{279} \mathrm{JWCC}\left(\mathrm{C}^{3} \mathrm{~B}\right)$, s.a. 1095. Cf. WMGP, 4.158.

${ }^{280} \mathrm{JWCC}\left(\mathrm{C}^{3} \mathrm{~B}\right)$, s.a. 1095. Cf. WMGP, 4.155, 156.

${ }^{281} \mathrm{JWCC}\left(\mathrm{C}^{3} \mathrm{~B}\right)$, s.a. 1095. Cf. WMGP, 4.157.

${ }^{282} \mathrm{JWCC}\left(\mathrm{C}^{3} \mathrm{BP}^{3}\right)$, s.a. 885. Cf. WMGP, 4.171.

${ }^{283}$ Possibly WMGP, 4.172.5.

${ }^{284}$ This section echoes diagrammatic genealogy of Woden in JWKings (C, p. 47). The language is quite different from that of textual genealogy that appears in $\mathrm{G}^{2}$, fol. $1 \mathrm{v}$ - an item that might available to the compiler if he were using $\mathrm{G}$ after it was augmented at Gloucester.
} 
fuit Frithewulf, qui fuit Finn, qui fuit Godwulf, qui fuit Getha, qui fuit Cetwa, qui fuit Beau, qui fuit Cewala, luel Sceldwa/ qui fuit Heremod, qui fuit Itermod, qui fuit Hatra, qui fuit Wala, qui fuit Beathwi, qui fuit Seth $\backslash$ Sem/ qui Saxonice dicitur Sceaf, ${ }^{285}$ qui fuit Noe. Habuit idem Woden septem filios, Wetha a quo regum Cantuariorum propago, Casare ab hoc regum Estanglorum ${ }^{r}$ progenies, Weothelgeat a quo regum prosapia, ${ }^{\text {s }}$ Wehadeah a quo Deirorum genealogia, Bealdeh a quo regum Westsaxonum et Ber|niciorum propago, Wigelfa a quo nulla regum prosapia, Winta a quo Lindisfarorum genealogia. ${ }^{286}$

83. De Regibus CANTUARIORUm. ${ }^{287}$ Anno Domini .cccc.lvi. Hengist adepta uictoria regnare cępit et primus Anglorum extitit rex Cantuariorum, regnauitque annis .xxiiii. Cui filius suus Ogga uel Orith successit, regnauit annis. xxiiii. Cui successit filius eius Ocsa uel Oisc, et regnauit annis .xxii. Cui filius eius Eormenrig successit, regnauitque annis .xxv. Cui Ethelbert filius eius succedens, regnauit annis .Ivi. Cuius regina Berta nomine Francorum regis cuiusdam extitit filia. Quorum filia sancta Ethelburga, Edwini regis Northanhymbrorum regina erat, quę monasterium in loco qui dicitur Limen $^{t}$ construxit, et ibi requiescit. Eiusdem regis Ethelberhti soror rigula, Estsaxonum regina, genuit sanctum Sebertum eiusdem prouincię regem. Decessit rex Ethelberhtus,

Primus et Anglorum petit alta polorum.

Cui filius eius Eadboldus successit, qui rebus ęcclesię, quantum ualuit in omnibus consulere ac fauere cupiens, diuinis se mancipare preceptis studuit. Huius regina Emma, regis Francorum extitit filia. Quorum filia sancta Eanswitha, quę in loco qui Folkestre dicitur requiescit, et regulus [fol. 18v] Eormenredus extitit filius. Cui Eormenredo regina sua Oslaua quatuor filias et duos peperit, sanctam scilicet Eormemburgam, quę fuit regina Merewaldi regis Westanglorum, sanctam Ermenburgam, sanctam Etheldridam, sanctam Eormengitham, sanctos martires Ethelredum ac Ethelbertum, quos Thunor, prępositus Egberti Cantuariorum regis ut ipse iusserat martirizauit. Decessit rex Eadboldus anno regni sui .xxv. et Ercombertum filium suum regem heredem reliquit. Huic regina sua sancta Sexburga, Annę regis Orientalium Anglorum filia, monasterium in Scepege construxit. Sancta Erkengota regis Erkemberti ac Sancte Sexburgę filia, Gualiam missa, sub matertera sua sancta

\footnotetext{
${ }^{285}$ In JWKings (C, p. 47), the words Saxonice Sceaf are interlined above Seth.

${ }^{286}$ A later gloss pater [?] Hengisti et Horsi appears in the upper margin above this item.

${ }^{287}$ This section is closer to JWChronicula (fols. 64v-66r), except in its final sentence, a note about the duration of the kingdom of Kent, which suggests collation with JWKings (C, p. 48). The notes that follow draw attention only to the more significant variants between these versions of the accounts.
} 
Ethelburga abbatissa in Brigensi monasterio usque ad finem uitę suę ${ }^{288}$ seruiuit, ibique requiescit. Altera filia sancta Ermengilda Wulferi regis Merciorum erat regina. Decessit rex Ercombertus anno regni sui .xxiiii., Egberto filio regni sedem relinquens. Qui .xi. regni sui anno decessit, succedente in regnum fratre suo Lothero. Qui uulneratus in pugna Australium Saxonum, quos contra eum Edricus filius Egberti incitauerat, mortuus est, qui ${ }^{289}$ uno anno et dimidio regnauit. Cui | frater suus Wichtredus succedens, ęcclesiam Sancti Martini in Dovera construxit. Decessit anno regni sui .xxxviii. ${ }^{290}$ filium suum Ethelbertum regni successorem relinquens. Qui anno regni sui .xxxi. ${ }^{291}$ decessit, cui frater suus Edbertus, qui et Pren successit. Quem rex Merciorum Kenulfus, pater Kenelmi martyris, dum Cantiam deuastaret, cepit, et secum in Merciam duxit. Cui successit Cuthredus, et anno <.viiii.> regni sui decessit. Cui Baldredus successit, quem Egbertus rex Westsaxonum regno expulit, regnumque Cantuariorum suo id est Westsaxonico regno, subdidit. Regnum Cantuariorum per .ccc.lxviii. annos stetit.

84. De REgibus Orientalium Anglorum. ${ }^{292}$ Orientalium Anglorum reges erant potentes, sed Redwaldus aliis ${ }^{293}$ omnibus extitit. Omnes enim australes Anglorum et Saxonum prouincię cum suis finibus ad confinium Humbrę fluminis, ei subjectę erant. Qui Ethelfridum regem Deirorum et Berniciorum in bello quo eius filius Reinhierus peremptus est, occidit, et Edwinum, Ellę filium, ut in regnum perueniret, iuuit. Cui alter filius eius Eorpnald in regnum successit, et Edwino rege persuadente, fidem Christi cum sua prouincia suscepit. Quem non multo post Rigbertus, uir gen[fol. 19r]tilis in bello occidit. Cui frater suus ex parte matris Sanctus Sigebertus successit. Hic sancto Furseo, ad se de Hibernia uenienti, possessiones ac locum construendi monasterium, in castro quodam quod lingua Anglorum Cnobberesburch uocatur, dedit, et pro amore cęlesti relicto regno, et cognate suo Eirico commendato, in monasterio quod sibi fecerat, monachus factus est. Et multo post tempore, contra regem Merciorum Pendam, ad confirmandum militem, inuitus in certamen

\footnotetext{
288 JWChronicula (fol. 65v); JWKings (C, p. 48): Deo

289 JWChronicula (fol. 65v-66r): congregauerat. Anno regni sui .xii. inter medendum mense Februario defunctus est. Cui successit in regnum Edricus filius fratris sui Ecgberti, ac...; JWKings (C, p. 48): aggregauerat, anno regni... Ecgberti, ac...

${ }^{290}$ JWChronicula (fol. 66r): .xxxiiii., JWKings (C, p. 48): tricesimo quarto

291 JWChronicula (fol. 66r): .xxxvi., JWKings (C, p. 48): tricesimo sexto

${ }^{292}$ This section closely echoes the summary history of the East Anglian royal house in JWChronicula (fols. 66r-67r). Cf. JWKings (C p. 49).

${ }^{293}$ JWChronicula (fol. 66r): illis
} 
ductus, suę professionis non immemor, dum nisi uirgam tantum in manu habere noluit, occisus ${ }^{294}$ unacum rege Egrico. Quorum regni successor factus est Anna, filius Hem, fratris Redwaldi, cuius filia, Sancta Sexburga, Ercomberto regi Cantuariorum coniugio copulata est. Altera, sancta Ethelburga, in Guallia, in Brigensi monasterio abbatissa facta est. Tercia sancta Etheldritha, Heliensis abbatissa, facta est. ${ }^{295}$ Quarta, sancta Wichtgitha, eiusdem monasterii sanctimonialis extitit. ${ }^{296}$ Quarum pater Anna rex, a Penda rege Merciorum, occisus, fratrem suum Ethelherum regni heredem reliquit. Qui de regina sua sancta Hereswitha, sorore sanctę Hildę abbatissę, duos filios, Aldulfum et Alwoldum genuit. Peremptus est autem in | bello ab Oswiu cum Penda rege, cui germanus suus Ethelwold successit. Quo defuncto, Aldulf regnum suscepit, et annis nonnullis tenuit. Post cuius mortem frater eius Alwold regnauit. Regnante autem rege Merciorum Offa, Beorna regnauit in Estanglia, et post illum Ethelredus, qui de regina sua Leofruna sanctum habuit Egielbertum. Hic post patrem breui tempore regnum tenuit Orientalium Anglorum. Innocenter enim sub pacis fędere occisus est ab Offa rege Merciorum. Deinde perpauci reges in Estanglia per .1xii. ${ }^{297}$ annos regnauerunt, ${ }^{298}$ quoad ultimus eorum Sanctus Edmundus, nactus est culmen regiminis. Hynguar quem Danus Danorum rexque paganus, ex his ${ }^{299}$ multauit nece sancta martyrizauit. Ex quo tempore Angli Saxones in Orientali Anglia ${ }^{300}$ desiere annis fere quinquaginta. Postmodum idem regnum partim sub Danicis regibus, partim sub comitibus premebatur, et uastabatur quousque rex Westsaxonum Edwardus senior omnes Danos paganos regno expelleret, et regnum Orientalium Anglorum Westsaxonico regno subiceret.

85. De Regibus Orientalium SAXONum. ${ }^{301}$ Orientalium Saxonum [fol. 19v] reges fere semper aliis parebant regibus, frequentius tamen et diutius regibus Merciorum, qui scilicet ante Sebertum, Ethelberti regis nepotem ex sorore Rigula, demonicis seruiebant cultibus. Ille uero, predicante Mellito episcopo Lundoniensi, ueritatis uerbum cum sua gente primus illorum suscepit.

\footnotetext{
${ }^{294}$ JWChronicula (fol. 66v), and JWKings (C, p. 49), add est

${ }^{295}$ JWChronicula (fol. 66v); JWKings (C, p. 49): prius Northymbrorum regina, et post Eliensus extitit abbatissa

${ }^{296}$ JWChronicula (fol. 66v; JWKings (C, p. 49): erat femina

${ }^{297}$ JWChronicula (fol. 67r); JWKings (C, p. 49): .lxi.

${ }^{298}$ JWChronicula (fol. 67r), adds potentes

${ }^{299}$ JWChronicula (fol. 67r): penis

${ }^{300}$ JW Chronicula (fol. 67r), adds regnare

${ }^{301}$ This section closely echoes the summary history of the East Saxon royal house in JWChronicula (fols. 67r-68r). Cf. JWKings (C, p. 49).
} 
Proque fide uera, scandens post celica regna, ${ }^{302}$

filios suos Serredum et Sewardum qui pagani perdurauerant, regni temporalis reliquit heredes. Hi paruopost tempore in pugna sunt occisi. Quibus successit Sigebertus cognomento paruus, ipsius ${ }^{303}$ Sewardi filius. Quo mortuo, regimen regni suscepit Sigebertus, Sigebaldi filius. Hic Oswiu regis Northanhimbrorum hortatu, in Christum credens, a Finano Lindisfarnensi episcopo .ii. baptizatus est in Norhumbria. Quo regnante, Estsaxones fidem, quam pridem abiecerant, Cead Lundoniensi episcopo secundo, fratre Sancti Ceddę Merciorum episcopi quinti, predicante, receperunt. Longo autem post tempore occisus est a suis propinquis, quia euangelica precepta seruare, suis inimicis nimium parcere, et factas ab eis iniurias placida solebat mente dimittere. Cui frater suus Swithelmus in regnum successit, et ab ipso Cead in Estanglia bap|tizatus est. Cui post mortem Sebbi filius Sewardi, filii regis Sancti Seberti, et Sighere, filius regis Sigeberti parui, regni gubernacula tenuerunt. Post decessum Sigheri, Sebbi regni gubernacula rexit. Qui anno regni sui, .xxx. a Waldero, Lundoniensi episcopo, monachicum suscepit habitum, et defunctus ${ }^{304}$

Conscendit cęlum regem regum uisurus in euum. ${ }^{305}$

Pro quo filii eius Sighardus et Sueredus regnauerunt. Quorum post mortem, Offa filius Sighere regis, in regem leuatur. Hic iuuenis amantissimę ętatis, hominibusque ${ }^{306}$ suę gentis ad tenenda seruandaque regni sceptra exoptatissimus, suasu et hortatu sanctę Kinesuithę, regis Merciorum Pendę filię quam adamauerat, reliquit patriam et regnum pro Christo, et cum rege Merciorum Kenredo, et sancto Egwino, Wictiorum episcopo quarto, ${ }^{307}$ Romam petiit. Vbi attonsus, et in monachico habitu uitam complens, ad uisionem beatorum apostolorum,

Glorificam meruit conscendere felix. ${ }^{308}$

Cui in regnum successit Selredus Sancti Sigeberti regis filius. Quo perempto anno regni sui .xxxviii. Suitharedus regnum obtinuit, ac aliquantis annis tenuit. Cuius post mortem reges perpauci super Estsaxones regnau<ere..." ...West>saxonum Ecgberto se dedebant et ei suis [fol. 20r] successoribus parebant, sicque regnum Estsaxonum, Westsaxonico regno cessit.

\footnotetext{
${ }^{302}$ Another leonine hexameter with bisyllabic rhyme, shared with JWChronicula (fols. 67rv).

${ }^{303}$ JWChronicula (fol. 67v); JWKings (C, p. 49): eiusdem

${ }^{304} \mathrm{JWChronicula}$ (fol. 67v): et breui post tempore

${ }^{305}$ Another line of rhyming verse, almost identical to that at corresponding point in JWChronicula (fols. 67v), except that the latter has Christum instead of regem regum.

${ }^{306}$ JWChronicula (fol. 67v). Cf. JWKings (C, p. 49): et uenustatis, totęque

${ }^{307}$ JWChronicula (fol. 68r): .iii .

${ }^{308}$ In JWChronicula (fols. 67r-68r), this verse is rendered as Glorificam celis meruit conscendere felix.
} 
86. De REgIBUS Merciorum. ${ }^{309}$ Merciorum reges, multis annis cultibus ydolatrię dediti, paulatim regni sui fines dilatauere. Sed Penda, qui regnare cępit anno Domini .dc.xxvi. multo latius quam aliquis suorum prędecessorum dilatauit. Duos etenim reges Northanhymbrorum, Sanctum Edwinum ac Sanctum Oswaldum, et tres reges Estanglorum, Sanctum Sigebertum, Egricum et Annam, occidit in bello. Cui regina sua Kinesuitha quinque filios, Peadam scilicet, Wulferum, Sanctum Ethelredum, Sanctum Merewaldum, Mercelorum, et duas filias Kineburgam et Sanctam Kinesuitham peperit. Regnauit autem annis .xxx. non plene, quem rex Northanhymbrorum Oswi cum .xxx. ducibus in bello peremit, et regnum eius suę ditioni subegit. Filio tamen eius Peadę, qui a patre suo Mediterraneis Anglis princeps constitutus, in Norhumbria a Finano episcopo est baptizatus, eo quod suus esset cognatus, habuit enim in coniugem filiam eius Elfledem, regnum Merciorum Australium dedit. At ille anno regni sui . $i^{\circ}$. peremptus est nefarie. Tribus annis post interfectionem Pendę regis completis, eius filium Wulferum duces Merciorum leuantes in regem, fines suos fortiter | simul et libertatem receperunt. Hic primus ${ }^{310}$ Merciorum lauacrum regenerationis suscepit, et filiam Ercomberti regis Cantuariorum ac reginę illius sanctę Sexburgę, sanctam Ermenhildam in coniugem accepit, ex qua genuit Kenredum et Wereburgam uirginem sanctissimam. Germanus uero ipsius, Westanhecanorum ${ }^{v}$ rex, Sanctus Merewaldus, filiam Ermenredi regis, fratris eiusdem Erconberti regis, Sanctam Ermemburgam, matrimonio sibi copulauit, et ex ea tres filias, Sanctam uidelicet Mildburgam, Sanctamque Mildridam, Sanctamque Mildgitham, et unum filium Sanctum Merefinnum genuit. Quo mortuo, regnauit pro eo Mercellus ${ }^{311}$ frater eius. Quorum sororem Sanctam Kyneburgam rex Northanhymbrorum Alhfridus duxit uxorem. Quę carnalis copulę coniugio pro Dei amore relicto, monasterio quod fratres sui Wulfherus et Sanctus Ethelredus ${ }^{312}$ construxerunt, et ab ipsius nomine Kyneburgę Castrum uocauerunt, sanctimonialis efficitur. In quo etiam soror sua Kynesvitha sanctimonialem suscepit habitum. Decessit autem rex Wulfherus anno regni sui .xvii.. Cui successit germanus suus sanctus Ethelredus, qui regis Northanhymbrorum Egfridi sororem Ostridam accępit in coniugem, ex [fol. 20v] qua filium Ceolredum habuit. Anno uero regni sui .xxx. monachus factus, Ceonredo suo fratrueli regnum dedit. Qui regni sui anno quinto seculum

\footnotetext{
${ }^{309}$ This section closely echoes the summary history of the Mercian royal house in JWChronicula (fol. 67r-69v). Cf. JWKings (C, p. 50).

${ }^{310}$ JWChronicula (fol. 68v), and JWKings (C, p. 50), add regum

${ }^{311}$ JWChronicula (fol. 68v) and JWKings (C, p. 50) have Mercelmus

312 JWChronicula (fol. 68v): ac AElfredus
} 
reliquit, Romam adiit, et in monachico habitu,

Vita decedit, cęlsaque cęli petit. ${ }^{313}$

Cui in regnum successit Ceolredus, patrui sui Ethelredi regis filius. ${ }^{314}$ Quem anno regni sui .xli. Beornredus tyrannus in Seggeswolde occidit, et regnum eius inuasit. Corpus uero regis Reopedine delatum tumulatur. ${ }^{315}$ Cuius patruelis Eanulphi nepos, Offa filius Thigferdi, eodem anno regni inuasorem Beornredum in bello peremit, et loco eius regnauit. Cui regina sua Kynethrida duas filias, Eadburgam quam rex Westsaxonum Brichtricus duxit uxorem, et Elfthridam quę uirgo permansit, unumque filium Egferthum peperit. Decessit autem regni sui anno .xxxix. Cui filius suus Egferthus successit, sed eodem anno decessit. Cui uir magnificus Kenulfus, filius Cuthberti, trinepotis Pibbę regis, Patris Pendę Regis, successit. Huic regina sua Alfdrida duas filias duas, Quendridam et Burgenildam,

In fontem celsum meritis genuitque Kenelmum. ${ }^{316}$

Decedens autem regni sui anno .xxiiii. Wincelcumbę $e^{317}$ requiescit, et heredem regni sui filium suum Kenolmum | reliquit. Quem eodem anno Quendrydę sororis insidiis,

Ascbert occidit, sic gaudia summa petiuit. ${ }^{318}$

Cui patruus suus Ceolwulf successit, sed post biennium regno expellitur, et Bernulf in regem accipitur. ${ }^{319}$ Qui biennio transacto ab Orientalibus Anglis in bello perimitur. Cui Ludecan suus propinquus successit, sed post biennium dum suum prędecessorem ulcisci uellet, ab Estanglis occiditur. Cui successit in regnum Wiglaf. Huic regina sua ${ }^{320}$ filium genuit Wimundum, qui de filia regis Merciorum Ceolwulfi Elfleda, sanctum habuit Wulstanum. ${ }^{321}$ Decedens Wilaf anno regni sui

\footnotetext{
${ }^{313}$ Another leonine, almost identical to that at corresponding point in JWChronicula (fol. 69r): Vita decedit celsa polique petit, whereas JWKings (C, p. 50), has uitam finuit. It should be noted that Cenred's death in Rome is in keeping with Bede, $H E, 5.19$ (p. 516), but at odds with the narrative set out in the Lives of St Ecgwine, which imply that he returned to England after his visit to the city: e.g. Byrhtferth of Ramsey, Vita S. Ecgwini Wigorniensis episcopi (BHL 2432), 3.3-5, ed. and trs. Lapidge, Lives of Oswald and Ecgwine (n. 232 above), 206-303, at 256-62.

${ }^{314}$ JWChronicula (fol. 69r); JWKings (C, p. 50), add Qui anno regni sui .ix. defunctus est, cui Athelbaldus filius Alwig filii scilicet Eoue fratris Pendę regis successit.

315 JWChronicula (fol. 69r): regaliter est tumulatum

${ }^{316}$ Another leonine echoed in JWChronicula (fol. 69r). Cf. JWKings (C, p. 50): sanctumque Kenelmum genuit

317 JWChronicula (fol. 69r), adds sepultus

${ }^{318}$ Cf. JWKings (C, p. 50): occiditur.

${ }^{319}$ JWChronicula (fol. 69r) and JWKings (C, p. 50): regnum suscipitur

${ }^{320}$ JWChronicula (fol. 69v) and JWKings (C, p. 50), add Kynethrytha

${ }^{321}$ Rightly Wistanum, as in JWChronicula (fol. 69v, and JWKings (C, p. 50).
} 
.$x$ iii. ${ }^{322}$ Beortulfum successorem reliquit. Huic regina sua Sehtbriht filium peperit Bereferthum, qui Sanctum peremit Winstanum. Cuius corpus ad Reopedin, monasterium tunc temporis famosum, delatum, in mausoleo aui sui Wiglaui humatum est. Sed $^{323}$ illius martyrio cęlestia non defuere miracula. Nam de loco quo innocenter peremptus est,

Lucida ter denis est uisa columpna diebus, Desuper effulgens, et cęli culmina tangens. ${ }^{324}$

Decessit autem rex Bertulfus, ${ }^{325}$ cui Burredus succedens, filiam Athwulfi regis Westsaxonum, Ethelswitham regis Ælfredi sororem, duxit uxorem. Quem paganus exercitus Danorum anno regni sui .xxii. regno expu- ${ }^{\mathrm{w}}$

<87. De REgIBUS WeStSAXONUM. $>^{326} \ldots$ [fol. 21r] Eadburgam, et tres alias peperit filias. Quarum unam coniugem duxit Ottho imperator Romanorum, alteram Karolus rex Francorum, terciam Sithricus rex Norhimbrorum. Ethelstanum autem ${ }^{327}$ primogenitum de Edgiua femina nobilissima habuit, et anno regni uicesimo quarto decessit. Cui filius eius Ethelstanus successit, et rex Anglię coronatus, ab omnibus imperator totius Britannię est pronunciatus, et anno regni sextodecimo Glaornię decessit. ${ }^{328}$ Cui frater eius Edmundus successit, cui regina sua Elgiua filios peperit Edwinum et Eadgarum. Quo in palatio miserabiliter occiso, germanus eius Eadredus regnum suscepit, et anno regni decimo decessit. Cui Edwinus, germani sui Edmundi filius, successit, et anno regni tercio ${ }^{329}$

${ }^{322}$ JWChronicula (fol. 69v); JWKings (C, p. 50): Hreopedune sepultus requieuit, cui Beorhtwlfus successit.

323 JWChronicula (fol. 69v); JWKings (C, p. 50): tumulatum est. Verum

${ }^{324}$ A couplet in which the second line is clearly leonine in form. This passage, together with other aspects of John's treatment of Wigstan, was inspired by a version of the Vita S. Wistani martyris (BHL 8975), ed. William D. Macray, Chronicon Abbatiae de Evesham ad Annum 1418, RS 29 (1863), 325-32, at 331: "Nam de loco in quo innocenter occisus est, columna lucis usque ad colum porrecta, omnibus incolis loci illius apparens, per triginta dies stabat perspicua." Cf. JWKings (C, p. 50): columna lucis usque ad celum porrecta omnibus eiusdem loci incolis per .xxx. dies conspicua stabat.

${ }^{325} \mathrm{JWChronicula}$ (fol. 69v), adds anno regni sui

${ }^{326}$ The closest match for this section, in so as it is known from the manuscript, occurs in JWKings (C, pp. 53-54). The West-Saxon royal account in JWChronicula (fols. 72r-73r, merges seamlessly back into the "mainstream" of its narrative when it reaches the earlier tenth century, a little beyond the point where $\mathrm{V}$ resumes after the lacuna between fols. 20 and 21.

327 JWKings (C, p. 53), adds filium

${ }^{328}$ The author is possibly summarising JWKings (C, p. 53): "et super omnes prouincias Anglię usque ad flumen Hymbrę regnauit, ac prius reges Walanorum, dein Scottorum, Northymbrorym, Stretuuadalorum reges in deditionem accept. Quo mortuo, filius suus Æthelstanus ex... ." But compare also JWCC, s.a. 940, where John gives the length of Æthelstan's reign as 16 years and Gloucester as the place where he died. Cf. also JWChronicula (fol. 73v); Winchcombe Chronicle (n. 57 above), s.a. 940.

${ }^{329}$ JWKings (C, p. 53): .iiii ${ }^{\text {to }}$. 
decessit. Cui frater eius ${ }^{330}$ Eadgarus anno ętatis suę sextodecimo successit. Hic habuit ex Eneda, femina generosissima, Sanctum Edwardum, et de sancta Wiltrida Sanctam Edgitham. De regina uero Elftrida, Edmundum et Eielredum filios habuit. Cuius regni anno quarto Sanctus Ethelwoldus episcopus in Veteri Monasterio Wintonie, et anno decimo Sanctus Oswaldus Wigornię, eius iussu, expulsis clericis, monachos constituere. Decessit autem | anno regni sui tricesimo secundo 331 Edwardum filium regni heredem relinquens. Qui anno regni sui tercio, iussu ${ }^{332}$ Elftride occiditur. Cui in regnum successit frater eius Agelredus. Hic ex Agelgiua, comitis Egelberti filia, tres filios habuit, Edmundum, et Ędwinum, et Ethelstanum, ac Edgiuam filiam. Ex Emma uero, Ricardi comitis Normannorum filia, duos filios suscepit, Alfredum et Eadwardum. Decessit autem anno regni tricesimo nono, cui filius eius Edmundus cognomento Ferreum Latus successit. Qui duos filios, Edmundum et Edwardum ex quadam nobilis prosapie femina habuit, sed eodem anno dolis Edrici Steone perimitur. Cuius post mortem Cnutus Suani regis filius, qui septem mensibus ante mortem regis Egelredi Angliam magna cum classe hostiliter adierat, regnum suscepit, et prędictos filios regis Edmundi in exilium misit. Quorum unus scilicet Edmundus in adolescentia mortuus est in $\mid H / u n g e r i a$. Edwardus uero Agatham filiam germani imperatoris Henrici tercii in coniugem accepit, ex qua Margaretam reginam Scotie, et Cristinam uirginem, et clitonem Eadgarum habuit. ${ }^{333}$ Nonodecimo anno rex Chutus [fol. 21v] filio suo Hardecnuto, quem ei peperit regina Emma, rege constituto in Danubio, decessit. Cui filius eius Haroldus, quem ex Hamtoniensi Elfgiua habuit, in Anglia successit, et quinto anno post obitum patris decessit. Cui frater eius Hardecnutus successit, et tercio anno regni decessit. Cui frater suus ex parte matris Edwardus \sanctus/ filius Egelredi regis successit. ${ }^{334}$ Anno regni sui uicesimo tercio, rex Anglorum Edwardus Lundonię decessit. Cui ex ipsius electione et concessione, comes Haraldus filius Godwini Westsaxonum ducis, et Gythe sororis regis Danorum Suani patris sancti Cnuti martiris successit. Qui de regina Aldgetha $<$ filia $>$ comitis Algari habuit filium Haroldum. Qui eodem anno a Normannorum comite Willelmo Bastard peremptus est in bello, cui et ipse Willelmus in regnum successit. Hic de regina Mat $\mid$ h/ilda quatuor filios habuit: ${ }^{335}$ Robertum Curtehosa, Willelmum Rufum, Ricardum, Henricum regem. Et postquam uiginti annis, mensibus

\footnotetext{
${ }^{330}$ JWKings (C, p. 53): germanus suus

331 JWKings (C, p. 53): ętatis .xxxii. regni uero .xvi.

332 JWKings (C, p. 53) adds nouerce sue

333 JWKings (C, p. 53): suscepit. Anno uero regni sui nono decimo

334 To this point, this section matches most closely JWKings (C, p. 53).

${ }^{335}$ In JWKings (C, p. 54), John records that Matilda bore William three sons-Robert, William and Henry; but in JWCC, s.a. 1100, he mentions Richard who, like his older brother William II, "perished in the New Forest". This Richard is thought to have died there between 1069 and 1075: see Orderic, Historia Ecclesiastica (n. 113 above), 3:114.
} 
decem, diebus uigenti et octo, genti Anglorum pręfuit, regnum cum uita perdidit. ${ }^{336}$ Cui filius eius Willelmus Rufus successit, et postquam tredecim annos, minus | triginta et octo diebus regnauerat, ${ }^{337}$ in prouincia Iutharum in Noua Foresta sagitta percussus sine filiis occubuit. Cui frater eius iunior Henricus successit IN REGNUM".

University of Lancaster

\footnotetext{
${ }^{336}$ JWKings (C, p. 54): et anno regni uicesimo secundo in Normannia decessit.

${ }^{337}$ JWKings (C, p. 54): et anno regni tertio decimo.
} 
$\{$ Textual notes to Cronica de Anglia\}

a prouincia] prouinc $\mathbf{V}$

b Gens] ens $\mathbf{V}$

c cessati] $\operatorname{sic} \mathbf{V}$

d Interlined by a later hand.

e Interlined by a later hand.

f Interlined by a later hand.

g Interlined by a later hand.

h episcopatum] -tum is written over an erasure $\mathbf{V}$

i ambo rebus] ambobus $\mathbf{V}$

j ora] $h$ has been erased before $\operatorname{ora} \mathbf{V}$

$\mathrm{k} \quad$ xiiii $^{\text {us }}$ ] There is a space or erasure of about four letters before this numeral.

1 .deccc.lxxx.viii.] $\operatorname{sic} \mathbf{V}$

$\mathrm{m} \quad$ Interlined by a later hand.

n Interlined by a later hand.

o Anglia] Corrected from Anglię V

$\mathrm{p} \quad$ Interlined by a later hand.

q Celsi] causi $\mathbf{V}$

r Estanglorum] Estaaglorum

s prosapia] Followed by a space of about four letters $\mathbf{V}$

t Limen] Corrected from Limenstre $\mathbf{V}$

u regnau $<$ ere ...West $>$ saxonum] Owing to severe abrasion there is gap here of some fifteen letters. It cannot, unfortunately, be filled using JWKings or JWChronicula as both are substantially fuller at this point. JWChronicula (fol. 68r), for example, has ...regnauere proprii. Nam eodem anno quo regnum defecit Cantwariorum cum ipsis et cum Suthsaxonibus strenuo regi Westsaxonum Ecgberto sponte se dedebant....

v Westanhecanorum] Westanbecanorum $\mathbf{V}$

w expu-] At least one, probably two folios are missing at this point. They are likely to have contained material from the conclusion of the JWKings-namely, the conclusion of his account of Mercian kings, his accounts of the Northumbrian kings since it follows at this point in C, p. 5, and the first half of his account of the West-Saxon kings, since it is source of what follows when the MS 
resumes.

$\mathrm{x}$ REGNUM] The final four fifths of the column are blank $\mathbf{V}$ 